\title{
Emission trends and mitigation options for air pollutants in East
}

\section{Asia}

\author{
S. X. Wang ${ }^{1,2}$, B. Zhao ${ }^{1}$, S. Y. Cai ${ }^{1}$, Z. Klimont ${ }^{3}$, C. P. Nielsen ${ }^{4}$, T. Morikawa ${ }^{5}$, J. H. Woo $^{6}$, Y. Kim ${ }^{6}$, X. Fu ${ }^{1}$, J. Y. Xu ${ }^{1}$, \\ J. M. Hao ${ }^{1,2}$, and K. B. He ${ }^{1,2}$ \\ ${ }^{1}$ State Key Joint Laboratory of Environment Simulation and Pollution Control, School of Environment, \\ Tsinghua University, Beijing 100084, China \\ ${ }^{2}$ State Environmental Protection Key Laboratory of Sources and Control of Air Pollution Complex, \\ Beijing 100084, China \\ ${ }^{3}$ International Institute for Applied System Analysis, Laxenburg, Austria \\ ${ }^{4}$ Harvard China Project, School of Engineering and Applied Sciences, Harvard University, 29 Oxford St, \\ Cambridge, MA 02138, USA \\ ${ }^{5}$ Japan Automobile Research Institute, Tsukuba, Japan \\ ${ }^{6}$ Department of Advanced Technology Fusion, Konkuk University, Seoul, South Korea
}

Correspondence to: S. X. Wang (shxwang@tsinghua.edu.cn)

Received: 18 December 2013 - Published in Atmos. Chem. Phys. Discuss.: 27 January 2014

Revised: 17 May 2014 - Accepted: 19 May 2014 - Published: 1 July 2014

\begin{abstract}
Emissions of air pollutants in East Asia play an important role in the regional and global atmospheric environment. In this study we evaluated the recent emission trends of sulfur dioxide $\left(\mathrm{SO}_{2}\right)$, nitrogen oxides $\left(\mathrm{NO}_{\mathrm{x}}\right)$, particulate matter (PM), and non-methane volatile organic compounds (NMVOC) in East Asia, and projected their future emissions up until 2030 with six emission scenarios. The results will provide future emission projections for the modeling community of the model inter-comparison program for Asia (MICS-Asia). During 2005-2010, the emissions of $\mathrm{SO}_{2}$ and $\mathrm{PM}_{2.5}$ in East Asia decreased by 15 and $12 \%$, respectively, mainly attributable to the large-scale deployment of flue gas desulfurization (FGD) at China's power plants, and the promotion of highly efficient PM removal technologies in China's power plants and cement industry. During this period, the emissions of $\mathrm{NO}_{\mathrm{x}}$ and NMVOC increased by 25 and $15 \%$, driven by rapid increase in the emissions from China due to inadequate control strategies. In contrast, the $\mathrm{NO}_{\mathrm{x}}$ and NMVOC emissions in East Asia except China decreased by $13-17 \%$, mainly due to the implementation of stringent vehicle emission standards in Japan and South Korea. Under current regulations and current levels of implementation, $\mathrm{NO}_{\mathrm{x}}$, $\mathrm{SO}_{2}$, and NMVOC emissions in East Asia are projected to increase by about one-quarter over 2010 levels by 2030, while
\end{abstract}

$\mathrm{PM}_{2.5}$ emissions are expected to decrease by $7 \%$. Assuming enforcement of new energy-saving policies, emissions of $\mathrm{NO}_{\mathrm{x}}, \mathrm{SO}_{2}, \mathrm{PM}_{2.5}$ and NMVOC in East Asia are expected to decrease by $28,36,28$, and $15 \%$, respectively, compared with the baseline case. The implementation of "progressive" end-of-pipe control measures would lead to another onethird reduction of the baseline emissions of $\mathrm{NO}_{\mathrm{x}}$, and about one-quarter reduction of $\mathrm{SO}_{2}, \mathrm{PM}_{2.5}$, and NMVOC. Assuming the full application of technically feasible energy-saving policies and end-of-pipe control technologies, the emissions of $\mathrm{NO}_{\mathrm{x}}, \mathrm{SO}_{2}$, and $\mathrm{PM}_{2.5}$ in East Asia would account for only about one-quarter, and NMVOC for one-third, of the levels of the baseline projection. Compared with previous projections, this study projects larger reductions in $\mathrm{NO}_{\mathrm{x}}$ and $\mathrm{SO}_{2}$ emissions by considering aggressive governmental plans and standards scheduled to be implemented in the next decade, and quantifies the significant effects of detailed progressive control measures on NMVOC emissions up until 2030. 


\section{Introduction}

Air pollutant emissions in East Asia contribute a large share of the global emissions. Cofala et al. (2012) reported that East Asia contributes about 36, 29, and $36 \%$ to global emissions of sulfur dioxide $\left(\mathrm{SO}_{2}\right)$, nitrogen oxides $\left(\mathrm{NO}_{\mathrm{x}}\right)$, and particulate matter less than or equal to $2.5 \mu \mathrm{m}\left(\mathrm{PM}_{2.5}\right)$, respectively, much more than those of the United States and Europe. Moreover, both emission calculations and satellite observations indicate that $\mathrm{NO}_{\mathrm{x}}$ emissions in China have experienced rapid increase during 1995-2010, with annual average growth rates ranging between 5.5 and $7 \%$ (Zhao et al., 2013c; Zhang et al., 2007, 2012a). As a result, emissions in East Asia have greatly degraded regional air quality and visibility (Wang and Hao, 2012; X. Y. Zhang et al., 2012) and damaged human health (WB and SEPA, 2007). They also affect air quality and climate forcing beyond the region through the outflow that travels across the Pacific (Liu et al., 2003). In light of this situation, the control of emissions in East Asia is very important for the improvement of regional and global atmospheric environment.

With the objectives of air quality improvement and mitigation of climate change, the countries of East Asia, e.g., China, Japan, and South Korea, have taken substantial measures to improve energy efficiency and reduce emissions of air pollutants. These measures have often been stringent and have been rapidly enhanced. During 2006-2010, China set a target to reduce energy use per unit of gross domestic product (GDP) and national $\mathrm{SO}_{2}$ emissions by 20 and $10 \%$, respectively (The State Council of the People's Republic of China, 2006). During 2011-2015, China plans additional 16, 10, and $8 \%$ reductions for energy use per unit GDP, $\mathrm{NO}_{\mathrm{x}}$ emissions, and $\mathrm{SO}_{2}$ emissions, respectively (The State Council of the People's Republic of China, 2011). Japan has taken measures to meet its commitments under the Kyoto Protocol, which require that annual $\mathrm{CO}_{2}$ emissions during 2008-2012 should be $6 \%$ lower than those of 1990 (IEA, 2008). The vehicle emission standards in China, Japan, and South Korea have also been updated repeatedly in the past decade. A number of studies have investigated the recent emission trends in East Asia (or specific countries therein) and the effects of typical control policies (e.g., reductions in China's $\mathrm{SO}_{2}$ emissions since 2005 both by observations from satellites ( $\mathrm{Li}$ et al., 2010), and by bottom-up emission estimations (Lu et al., 2010, 2011; Klimont et al., 2013)). Some studies also estimated the trends of the emissions of $\mathrm{NO}_{\mathrm{x}}$ (Zhang et al., 2012a; Lin et al., 2010b; Zhao et al., 2013c) and particulate matter (PM) (Lin et al., 2010a; Lu et al., 2011). Kurokawa et al. (2013); Zhao et al. (2013a, d) and estimated the recent emission trends of multiple air pollutants. Future emissions were also predicted by previous studies (Streets and Waldhoff, 2000; Klimont et al., 2001, 2009; Cofala et al., 2007, 2012; Ohara et al., 2007; Xing et al., 2011; Zhao et al., 2013c). However, most of these projections were based on emissions for 2005 or earlier and did not consider more recent, sometimes dramatic, changes. The latest projections include Cofala et al. (2012) and Zhao et al. (2013c). Cofala et al. (2012) projected global emissions of $\mathrm{SO}_{2}, \mathrm{NO}_{\mathrm{x}}$, and $\mathrm{PM}_{2.5}$ for four energy scenarios developed by IEA (2012a), but did not envisage further end-of-pipe mitigation measures in the future. Zhao et al. (2013c) developed six $\mathrm{NO}_{\mathrm{x}}$ emission scenarios for until 2030 based on a 2010 emission inventory, and quantified the effects of various control policies, but did not analyze other air pollutants.

Although there have been a number of studies of recent and future emission trends in East Asia, they are inadequate for the development of broadly effective air quality and climate mitigation policies. First, future control measures must be developed while taking full account of the latest policies; a comprehensive and up-to-date review for the entire region is currently lacking in the literature. As described above, the base year of most projections was 2005 or earlier, and therefore they underestimated China's economic growth over the last decade, especially from 2006 to 2010 . These early projections also did not anticipate new emission control policies announced in 2011 under China's 12th Five-Year Plan (for the period of 2011-2015; The State Council of the People's Republic of China, 2011), nor a number of emission standards released after 2010, both of which may fundamentally alter the future emission pathways. The most recent projections (Cofala et al., 2012; Zhao et al., 2013c) considered only specific pollutants or specific sets of control measures, providing only partial insight into the future trends of all major air pollutants. Second, the attainment of stringent ambient air quality standards (e.g., China's standard of $35 \mu \mathrm{g} \mathrm{m}^{-3}$ for the annual average $\mathrm{PM}_{2.5}$ concentration, released in 2012) requires simultaneous reductions of multiple pollutants including $\mathrm{SO}_{2}, \mathrm{NO}_{\mathrm{x}}, \mathrm{PM}_{2.5}$, and non-methane volatile organic compounds (NMVOC) (Wang and Hao, 2012). Therefore, it is essential to consider a full range of relevant pollutants and scenarios at different stringency levels from the business-asusual case to the maximum feasible reduction case so that cost-effective emission controls can balance measures over all pollutants and control levels. Third, most studies focused on either end-of-pipe or energy-saving measures; their roles in integrated policies that simultaneously tackle multiple pollutants and climate forcers have been insufficiently studied. Considering the above, a comprehensive projection of emissions of multiple pollutants that incorporates the latest available base-year data, control measures scheduled for implementation, and other potential energy-saving and end-of-pipe measures at different stringency levels will contribute to both air pollution research and future decision making.

This study aims to evaluate the emission trends and mitigation options for multiple air pollutants in East Asia. The results will provide future emission projections for the modeling community of the model inter-comparison program for Asia (MICS-Asia), which aims to have a common understanding of the model performance and uncertainties in Asia. 
In Sect. 2, we review major control policies in East Asia over the last decade and evaluate their impact on air pollutant emissions during 2005-2010. Compared with previous studies of emission trends, we are particularly devoted to presenting a comprehensive review of the recent mitigation measures in this region, and illuminating the driving forces underlying the emission trends. In Sect. 3, we project future emissions of $\mathrm{SO}_{2}, \mathrm{NO}_{\mathrm{x}}, \mathrm{NMVOC}$, and $\mathrm{PM}$ up until 2030 for six emission scenarios (see Table 1), considering both energy-saving and end-of-pipe measures. In Sect. 4, we compare our results with other emission estimates as well as observations. In this study, the domain of East Asia consists of seven countries/regions, i.e., Chinese mainland, Japan, South Korea, North Korea, Mongolia, Hong Kong and Macao, and Taiwan. In the following text, China is short for mainland China. We focus on Japan, South Korea, and especially China, the key energy consumers in the region that dominate the emissions of air pollutants. Japan and Korea have relatively long histories of air pollution policies, while China has been enhancing its emission regulations in the last decade at an accelerating rate, has very ambitious future goals, and contributes the largest share of regional emissions. Therefore, developments in China are given special attention.

\section{Recent control measures and emission trends}

Recent control measures not only serve as the major driving forces of recent emission trends, but also lay the foundation for the development of future control policies. Control measures contributing to reductions of air pollutant emissions include energy-saving measures, e.g., energy efficiency improvements, cogeneration of heat and power, fuel substitution, and end-of-pipe control measures such as installations of dust collectors and flue gas desulfurization systems. A careful mix of measures to simultaneously address energy conservation, air pollution control and climate change mitigation is considerably cheaper than tackling each issue separately (Wang and Hao, 2012). In this section we review both recent energy-saving and end-of-pipe measures in East Asia, and then quantify their effects on recent emission changes.

\subsection{Energy-saving measures}

Japan, South Korea, and China have released a number of policies addressing energy conservation and climate change mitigation. Under the Kyoto Protocol, Japan committed to the reduction of its greenhouse gas (GHG) emissions by $6 \%$ during 2008-2012 from the base year of 1990. In the New National Energy Strategy formulated in May 2006, the Japanese government set a long-term target to improve energy intensity of GDP by an additional $30 \%$ by 2030 (IEA, 2008). The government of South Korea has made a commitment to reduce its GHG emissions $30 \%$ by 2020 compared to its business-as-usual projection (IEA, 2012b). The
Chinese government has set a target to reduce $\mathrm{CO}_{2}$ emissions per unit GDP by 40-45\% by 2020 compared with 2005 levels (Wang and Hao, 2012). Total energy consumption in East Asia increased by $31 \%$ during 2005-2010. China experienced the fastest increase, $43 \%$, driven by its rapid GDP growth rate, while Japan's energy consumption decreased during these five years due to a lower GDP growth rate and stringent energy-saving policies. The growth rate of South Korean energy consumption was intermediate those of China and Japan, at $19 \%$.

\subsubsection{Power plants}

The energy consumption of China's power sector increased sharply, by $35 \%$ during 2005-2010, due to the rapid increase in the demand for electricity (NBS, 2007, 2011a), while the energy consumption of Japan and South Korea remained relatively stable (http://www.iea.org/statistics/).

Up to $75 \%$ of China's power generation is coal fired (Zhao et al., 2013c). In contrast, the installed capacity in Japan is highly diversified, with coal, oil, natural gas, nuclear, and hydro contributing about $27,8,27,26$, and $8 \%$ of total electricity generation in 2010, respectively (http: //www.iea.org/statistics/). In South Korea, fossil fuels accounted for $69 \%$ of the total electricity generated, followed by nuclear at $30 \%$, in 2010 (http://www.iea.org/statistics/). While nuclear power has played central roles in Japan's and South Korea's low-carbon strategies, its share of Japanese power generation dropped dramatically to less than $10 \%$ in 2011 due to the Fukushima accident in March of that year (http://www.iea.org/statistics/), making the future of nuclear power in Japan quite uncertain. In South Korea, by contrast, nuclear power generation is expected to keep increasing in the next decade, with five reactors under construction and six more announced (IEA, 2012b). Given China's coal-intensive power generation mix, its government has been promoting the development of cleaner electricity through subsidy policies. By 2010, its capacities of hydro, natural-gas-fired, wind, and solar power generation had increased dramatically to 213, 27, 31, and 0.24 GW, respectively, or 1.82, 2.25, 23.8, and 3.43 times those of 2005 (China Electric Power Yearbook Committee, 2006, 2011).

China has also undertaken major efforts to improve the efficiency of coal-fired power generation. Its government forced the closure of $77 \mathrm{GW}$ of small and inefficient coalfired units during 2006-2010 (NDRC, 2011), with an additional $20 \mathrm{GW}$ of small units scheduled for early retirement during 2011-2015 (The State Council of the People's Republic of China, 2012). At the same time, the capacities of most new units built after 2005 have been $\geq 300 \mathrm{MW}$, driving their capacity share from $50 \%$ in 2005 to $73 \%$ in 2010 (The State Council of the People's Republic of China, 2012). The share of advanced supercritical and ultra-supercritical units, moreover, rose to over $13 \%$ (Li et al., 2012). As a result of these changes, the coal consumption per unit electricity 
Table 1. Definition of the energy and emission scenarios in this study.

\begin{tabular}{|c|c|c|c|}
\hline $\begin{array}{l}\text { Energy sce- } \\
\text { nario name }\end{array}$ & Energy scenario definition & $\begin{array}{l}\text { Emission } \\
\text { scenario } \\
\text { name }\end{array}$ & Emission scenario definition \\
\hline \multirow[t]{3}{*}{$\begin{array}{l}\text { Business-as- } \\
\text { usual } \\
\text { (BAU) }\end{array}$} & $\begin{array}{l}\text { The BAU scenario is based on current regula- } \\
\text { tions and implementation status (until the end } \\
\text { of 2010). }\end{array}$ & BAU[0] & $\begin{array}{l}\text { The BAU[0] scenario assumes the energy-saving } \\
\text { policies of the BAU scenario. For an end-of-pipe control strat- } \\
\text { egy, it assumes that all current regulations } \\
\text { (until the end of 2010) and the current implementation status in } \\
\text { all countries will be continued during 2011-2030. }\end{array}$ \\
\hline & & BAU[1] & $\begin{array}{l}\text { The BAU[1] scenario assumes the energy-saving policies of the } \\
\text { BAU scenario. For an end-of-pipe control strategy in China, it } \\
\text { assumes that new pollution control policies will be released and } \\
\text { implemented, representing a progressive approach towards fu- } \\
\text { ture environmental protection. For the other countries in East } \\
\text { Asia, the assumptions of the BAU[1] scenario are exactly the } \\
\text { same as the BAU[0] scenario. }\end{array}$ \\
\hline & & BAU[2] & $\begin{array}{l}\text { The BAU[2] scenario assumes the energy-saving policies of } \\
\text { the BAU scenario. For an end-of-pipe control strategy, it as- } \\
\text { sumes that the maximum technically feasible control technolo- } \\
\text { gies would be fully applied by } 2030 \text {, regardless of the economic } \\
\text { cost. }\end{array}$ \\
\hline \multirow[t]{3}{*}{$\begin{array}{l}\text { Alternative } \\
\text { policy } \\
\text { (PC) }\end{array}$} & $\begin{array}{l}\text { The PC scenario assumes that new energy- } \\
\text { saving policies will be released and more } \\
\text { strongly enforced, resulting in lifestyle changes, } \\
\text { structural adjustment, and energy efficiency im- } \\
\text { provement. }\end{array}$ & $\mathrm{PC}[0]$ & $\begin{array}{l}\text { The } \mathrm{PC}[0] \text { scenario assumes the energy-saving policies of the } \\
\mathrm{PC} \text { scenario, and the same end-of-pipe control strategy as the } \\
\text { BAU[0] scenario. }\end{array}$ \\
\hline & & $\mathrm{PC}[1]$ & $\begin{array}{l}\text { The PC[1] scenario assumes the energy-saving policies of the } \\
\text { PC scenario, and the same end-of-pipe control strategy as the } \\
\text { BAU[1] scenario. }\end{array}$ \\
\hline & & $\mathrm{PC}[2]$ & $\begin{array}{l}\text { The } \mathrm{PC}[2] \text { scenario assumes the energy-saving policies of the } \\
\mathrm{PC} \text { scenario, and the same end-of-pipe control strategy as the } \\
\text { BAU[2] scenario. }\end{array}$ \\
\hline
\end{tabular}

supplied by thermal power plants decreased from 370 to $333 \mathrm{gce} \mathrm{kWh}^{-1}$ during the same period (The State Council of the People's Republic of China, 2012).

\subsubsection{Industrial sector}

During 2005-2010, the energy consumption of China's industrial sector increased dramatically, at an annual average rate of $9.0 \%$ (cf. $7.4 \%$ for total energy consumption), due largely to the rapid increase of energy-intensive products, e.g., cement and steel (NBS, 2007, 2011a). However, driven by a target to reduce energy intensity per unit GDP by $20 \%$ from 2005 to 2010 , China mandated widespread replacement of outmoded production technologies with more energy-efficient ones. For example, the share of cement produced by precalciner kilns increased from $45 \%$ in 2005 to about $80 \%$ in 2010 . During the same period, the proportion of large units $\left(\geq 4000 \mathrm{td}^{-1}\right)$ of all precalciner kilns increased from 33 to $60 \%$ (Zhao et al., 2013c, d). The share of coke produced in machinery coke ovens (vs. traditional small ovens) increased from $82 \%$ in 2005 to $87 \%$ in 2010 (NBS, 2007, 2011; Huo et al., 2012); the share of blast furnaces larger than $1000 \mathrm{~m}^{3}$ increased from 48 to $61 \%$ over the same time period (The State Council of the People's Repub- lic of China, 2012). In effect, the average energy intensity of cement and crude steel production decreased by 29 and $12 \%$, respectively, from 2005 to 2010 (The State Council of the People's Republic of China, 2012).

While China's industrial sector has grown swiftly but only recently undertaken aggressive energy efficiency improvements, Japan's industrial sector has played a central role in national energy conservation for several decades (IEA, 2008). Major policies have included compulsory submission of energy-saving plans for large energy consumers, frequent on-site inspections, and subsidies to assist small companies in introducing energy-efficient equipment (IEA, 2008; Energy Conservation Center of Japan, 2011). These measures decreased the average energy consumption per ton of production of cement and crude steel by 6.3 and $5.6 \%$, respectively, from 2000 to 2010 (Wang, 2010). Japan's industrial energy use as a proportion of total energy use has declined from $26 \%$ in 2000 to $18 \%$ in 2010 (IEA, 2002, 2012b), and the share of coal and petroleum products of total energy consumption has decreased from 64 to $56 \%$ during 2000-2010 (IEA, 2002, 2012b).

Industrial energy consumption in South Korea has increased steadily in recent years, in part because its energy intensity (energy consumption per unit GDP) did not notably 
improve from the 1990s to 2006 (IEA, 2006). In 2008, South Korea set new targets for national energy intensity in its "Strategy for Green Growth": from 0.328 tonne of oil equivalent (toe)/US\$1000 in 2007 to 0.290 toe/US\$1000 in 2013, and 0.233 toe/US\$1000 in 2020. Enforcement of these policies is expected to occur mainly through "voluntary agreements" between the government and large companies (IEA, 2006, 2012b; UNEP, 2010).

\subsubsection{Residential sector}

Residential energy consumption in China and South Korea increased steadily during 2005-2010, driven by increases in total building area (NBS, 2007, 2008a, b, 2009, 2011a, b; http://www.iea.org/statistics/). During the same period, Japan's residential energy consumption decreased slightly, attributed to the stable demand for building space and aggressive energy-saving policies (IEA, 2008; http://www.iea. org/statistics/).

By the end of 2006, $96 \%$ of China's new buildings complied with the energy-saving design standard released in 1996 (THUBERC, 2009); this was succeeded by a more stringent standard in 2010 (The State Council of the People's Republic of China, 2012). The energy efficiency standards in Japan's building codes, first released in 1980 and strengthened in 1992 and 1999, have all been voluntary. As of $2005,30 \%$ of new houses and $85 \%$ of new buildings larger than $2000 \mathrm{~m}^{2}$ complied with the voluntary standards (IEA, 2008). In Korea, energy efficiency codes for buildings had long been relatively weak until a strong, performance-based design code applicable to large commercial buildings was issued in 2011 (IEA, 2006, 2012b).

Japan is a world leader in the energy efficiency of residential and commercial appliances. The Top Runner Program, which sets energy-efficiency targets for appliances based on the most energy-efficient products on the market, has been successfully enforced. For example, the efficiency of air conditioners and refrigerators increased by $68 \%$ (over 19972004) and $55 \%$ (1998-2004), respectively, both exceeding the targets of 66 and $31 \%$ (IEA, 2008; Energy Conservation Center of Japan, 2011). Similar programs have recently been promoted in South Korea and China (UNEP, 2010).

China has been promoting clean energy in the residential sector. Direct combustion of biomass in rural areas has been gradually replaced with commercial fuel in the last decade, and its share in rural cooking decreased from $38 \%$ in 2005 to $31 \%$ in 2010 . The production of biogas for residential use and ownership of solar water heaters both doubled during 2005-2010 due to subsidy policies.

\subsubsection{Transportation sector}

During 2005-2010, the energy consumption of China's transportation sector grew at an annual average rate of $10 \%$, attributed to explosive growth of the vehicle population (NBS,
2007, 2011a). In contrast, the transportation energy consumption in South Korea was stable and that of Japan declined (http://www.iea.org/statistics/).

The reduction in Japan's vehicle energy consumption is largely due to its fuel-efficiency standards, which are among the most aggressive in the world. For passenger vehicles, there was a consistent improvement in the average fuel economy from $13.5 \mathrm{~km} \mathrm{~L}^{-1}$ in 2000 to $17.8 \mathrm{~km} \mathrm{~L}^{-1}$ in 2009 (Energy Conservation Center of Japan, 2011). Japan was also the first country in the world to implement fuel efficiency standards for heavy-duty (freight) vehicles, which decreased

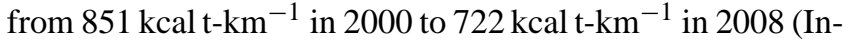
stitute of Energy Economics of Japan, 2010). Since 2004 China has also implemented fuel-efficiency standards for light-duty vehicles, leading to an increase in the efficiency of new gasoline passenger cars from $11.0 \mathrm{~km} \mathrm{~L}^{-1}$ in 2005 to $13.5 \mathrm{~km} \mathrm{~L}^{-1}$ in 2010 (Zhao et al., 2013c). An updated standard $\left(14.3 \mathrm{~km} \mathrm{~L}^{-1}\right.$ by 2015$)$ for passenger cars was issued in 2011. In 2006, the South Korean government introduced its first mandatory fuel-economy standards, requiring car manufacturers to meet average fuel economy standards of $12.4 \mathrm{~km} \mathrm{~L}^{-1}$ for vehicles with engines of less than 1500 cubic centimeters (IEA, 2006). In July 2009, a new fuel-economy standard of $17 \mathrm{~km} \mathrm{~L}^{-1}$ was announced (IEA, 2012b).

China has also launched several initiatives to promote electric vehicles, and their numbers reached 12000 by 2010 (Yang, 2012). The most recent development plan for newenergy vehicles (issued in 2012) aimed to increase the population of electric vehicles to 0.5 million and 5 million in 2015 and 2020, respectively, through a series of subsidy policies.

\subsection{End-of-pipe control measures}

\subsubsection{Power plants}

Due to their relatively large scales of energy use and emissions, power plants are usually subject to the most stringent control measures of all sectors. The penetration of major control technologies in the power sectors of China, Japan, and South Korea is summarized in Table 2.

In 2006, China set a target to reduce national $\mathrm{SO}_{2}$ emissions by $10 \%$ by 2010 over 2005 levels (Wang and Hao, 2012). By 2010, over $83 \%$ of coal-fired power plants (including about $88 \%$ of pulverized coal combustion plants, representing $560 \mathrm{GW}$ ) had installed flue gas desulfurization (FGD) (MEP, 2011). The recently released 12th Five-Year Plan aims for another $8 \%$ reduction in total $\mathrm{SO}_{2}$ emissions by 2015 , which would require nearly all coal-fired power plants to be equipped with high-efficiency FGD facilities (i.e., with at least $95 \%$ removal efficiency).

Low- $\mathrm{NO}_{\mathrm{x}}$ combustion technology (mainly low- $\mathrm{NO}_{\mathrm{x}}$ burners, LNB) was the major $\mathrm{NO}_{\mathrm{x}}$ control technology used in China's coal-fired power plants by 2010. The penetration of flue gas denitrification (selective catalytic reduction, SCR, 
Table 2. Propagation of major control technologies in the power sectors in China, Japan, and South Korea (\% of fuel use).

\begin{tabular}{|c|c|c|c|c|c|c|c|c|c|c|c|c|c|c|c|c|c|c|c|c|c|c|}
\hline \multirow{3}{*}{$\begin{array}{l}\text { Energy } \\
\text { technology }\end{array}$} & \multirow{3}{*}{$\begin{array}{l}\text { Control } \\
\text { technology }\end{array}$} & \multicolumn{6}{|c|}{ Base year } & \multicolumn{6}{|c|}{ BAU[0]/PC[0] } & \multicolumn{6}{|c|}{ BAU[1]/PC[1] } & \multirow{2}{*}{\multicolumn{3}{|c|}{$\begin{array}{c}\text { BAU[2]/PC[2] } \\
2030\end{array}$}} \\
\hline & & \multicolumn{3}{|c|}{2005} & \multicolumn{3}{|c|}{2010} & \multicolumn{3}{|c|}{2020} & \multicolumn{3}{|c|}{2030} & \multicolumn{3}{|c|}{2020} & \multicolumn{3}{|c|}{2030} & & & \\
\hline & & China & Japan & $\begin{array}{l}\text { South } \\
\text { Korea }\end{array}$ & China & Japan & $\begin{array}{l}\text { South } \\
\text { Korea }\end{array}$ & China & Japan & $\begin{array}{l}\text { South } \\
\text { Korea }\end{array}$ & China & Japan & $\begin{array}{l}\text { South } \\
\text { Korea }\end{array}$ & China & Japan & $\begin{array}{l}\text { South } \\
\text { Korea }\end{array}$ & China & Japan & $\begin{array}{l}\text { South } \\
\text { Korea }\end{array}$ & China & Japan & $\begin{array}{l}\text { South } \\
\text { Korea }\end{array}$ \\
\hline \multirow[t]{3}{*}{ Grate boilers } & CYC (PM) & 12 & - & - & 12 & - & - & 0 & - & - & 0 & - & - & 0 & - & - & 0 & - & - & 0 & - & - \\
\hline & WET (PM) & 88 & - & - & 88 & - & - & 100 & - & - & 100 & - & - & 100 & - & - & 100 & - & - & 0 & - & - \\
\hline & HED (PM) & 0 & - & - & 0 & - & - & 0 & - & - & 0 & - & - & 0 & - & - & 0 & - & - & 100 & - & - \\
\hline \multirow{7}{*}{$\begin{array}{l}\text { Pulverized coal } \\
\text { combustion }\end{array}$} & WET (PM) & 8 & 0 & 0 & 0 & 0 & 0 & 0 & 0 & 0 & 0 & 0 & 0 & 0 & 0 & 0 & 0 & 0 & 0 & 0 & 0 & 0 \\
\hline & ESP (PM) & 92 & 3 & 72 & 93 & 2 & 67 & 90 & 0 & 64 & 80 & 0 & 61 & 65 & 0 & 64 & 50 & 0 & 61 & 0 & 0 & 0 \\
\hline & HED (PM) & 0 & 97 & 28 & 7 & 98 & 33 & 10 & 100 & 36 & 20 & 100 & 39 & 35 & 100 & 36 & 50 & 100 & 39 & 100 & 100 & 100 \\
\hline & $\mathrm{FGD}\left(\mathrm{SO}_{2}\right)$ & 12 & 97 & 95 & 88 & 98 & 97 & 93 & 100 & 98 & 96 & 100 & 98 & 100 & 100 & 98 & 100 & 100 & 98 & 100 & 100 & 100 \\
\hline & $\mathrm{LNB}\left(\mathrm{NO}_{\mathrm{x}}\right)$ & 53 & 10 & 23 & 75 & 0 & 13 & 82 & 0 & 13 & 84 & 0 & 13 & 8 & 0 & 13 & 0 & 0 & 13 & 0 & 0 & 0 \\
\hline & $\begin{array}{l}\mathrm{LNB}+\mathrm{SNCR} \\
\left(\mathrm{NO}_{\mathrm{x}}\right)\end{array}$ & 0 & 0 & 5 & 1 & 0 & 5 & 1 & 0 & 5 & 1 & 0 & 5 & 6 & 0 & 5 & 7 & 0 & 5 & 0 & 0 & 0 \\
\hline & $\mathrm{LNB}+\mathrm{SCR}$ & 1 & 90 & 56 & 12 & 100 & 68 & 12 & 100 & 72 & 12 & 100 & 76 & 86 & 100 & 72 & 94 & 100 & 76 & 100 & 100 & 100 \\
\hline Fluidized bed & $\begin{array}{l}\text { WET (PM) } \\
\left(\mathrm{NO}_{\mathrm{x}}\right)\end{array}$ & 8 & - & - & 0 & - & - & 0 & - & - & 0 & - & - & 0 & - & - & 0 & - & - & 0 & - & - \\
\hline \multirow[t]{5}{*}{ combustion } & ESP (PM) & 92 & - & - & 100 & - & - & 90 & - & - & 80 & - & - & 65 & - & - & 50 & - & - & 0 & - & - \\
\hline & HED (PM) & 0 & - & - & 0 & - & - & 10 & - & - & 20 & - & - & 35 & - & - & 50 & - & - & 100 & - & - \\
\hline & $\begin{array}{l}\text { CFB-FGD } \\
\left(\mathrm{SO}_{2}\right)\end{array}$ & 17 & - & - & 53 & - & - & 66 & - & - & 80 & - & - & 100 & - & - & 100 & - & - & 100 & - & - \\
\hline & SNCR $\left(\mathrm{NO}_{\mathrm{x}}\right)$ & 0 & - & - & 0 & - & - & 0 & - & - & 0 & - & - & 30 & - & - & 80 & - & - & 70 & - & - \\
\hline & $\mathrm{SCR}\left(\mathrm{NO}_{\mathrm{x}}\right)$ & 0 & - & - & 0 & - & - & 0 & - & - & 0 & - & - & 5 & - & - & 20 & - & - & 30 & - & - \\
\hline \multirow{3}{*}{$\begin{array}{l}\text { Natural gas } \\
\text { power }\end{array}$} & $\mathrm{LNB}\left(\mathrm{NO}_{\mathrm{x}}\right)$ & 30 & 80 & 20 & 74 & 61 & 15 & 87 & 52 & 15 & 91 & 50 & 15 & 50 & 52 & 15 & 10 & 50 & 15 & 0 & 0 & 0 \\
\hline & $\begin{array}{l}\mathrm{LNB}+\mathrm{SNCR} \\
\left(\mathrm{NO}_{\mathrm{x}}\right)\end{array}$ & 0 & 0 & 0 & 1 & 0 & 0 & 1 & 0 & 0 & 1 & 0 & 0 & 5 & 0 & 0 & 9 & 0 & 0 & 10 & 0 & 0 \\
\hline & $\begin{array}{l}\mathrm{LNB}+\mathrm{SCR} \\
\left(\mathrm{NO}_{\mathrm{x}}\right)\end{array}$ & 0 & 20 & 30 & 5 & 39 & 46 & 5 & 48 & 50 & 5 & 50 & 54 & 45 & 48 & 50 & 81 & 50 & 54 & 90 & 100 & 100 \\
\hline
\end{tabular}

and/or selective non-catalytic reduction, SNCR) was only $1.1 \%$ in 2005 and $12.8 \%$ in 2010 (MEP, 2011). In the 12th Five-Year Plan, the Chinese government aims to reduce national $\mathrm{NO}_{\mathrm{x}}$ emissions by $10 \%$ from 2010 to 2015, and the key measure to meet this target is large-scale deployment of $\mathrm{SCR} / \mathrm{SNCR}$ facilities. The $\mathrm{NO}_{\mathrm{x}}$ emission control policies are described in more detail in our previous paper (Zhao et al., 2013c).

The emission control of primary particulate matter in China's power sector has achieved noticeable progress in the last decade. Since 2003, all new and rebuilt units have had to attain the in-stack concentration standard for PM of $50 \mathrm{mg} \mathrm{m}^{-3}$ (GB13223-2003). As a result, over $92 \%$ of pulverized coal units had installed electrostatic precipitators (ESPs) by 2005. In addition, fabric filters (FF) have been put into commercial use in recent years, and their penetration increased to $7 \%$ by 2010 (Zhao et al., 2013a). Furthermore, the rapid deployment of wet-FGD also helped to reduce PM emissions due to its ancillary benefit of PM removal (Zhao et al., 2010). In 2011, China's Ministry of Environmental Protection (MEP) announced a revised in-stack concentration standard for PM of $20 \mathrm{mg} \mathrm{m}^{-3}$ for environmentally sensitive regions and $30 \mathrm{mg} \mathrm{m}^{-3}$ for other regions.

In Japan, the application of best available technologies for controlling $\mathrm{SO}_{2}, \mathrm{NO}_{\mathrm{x}}$, and $\mathrm{PM}$ is required for most power generation units across the country. The penetration of wetFGD, LNB+SCR and high-efficiency dedusters (HEDs, e.g., FF and electrostatic-fabric integrated precipitator) is over $90 \%$ for all, having increased slightly during 2005-2010 (Klimont et al., 2009).

In South Korea, FGD systems have been installed at most power generation units; the penetration increased slightly, from 95 to $97 \%$, during 2005-2010. For $\mathrm{NO}_{\mathrm{x}}$, SCR has been the dominant control technology, with its share increasing from $56 \%$ in 2005 to $68 \%$ in 2010. About one-third of coalfired power generation units had been equipped with HED systems by 2010, and the rest was equipped with ESP equipment (NIER, 2010; NIER 2013; Clean Air Policy Supporting System, CAPSS, http://airemiss.nier.go.kr/).

\subsubsection{Industrial sector}

The penetrations of control technologies for industrial boilers and industrial processes are presented in Table 3, Table 4 and Supplement Table S1.

In China, $\mathrm{SO}_{2}$ and $\mathrm{NO}_{\mathrm{x}}$ control technologies have been rarely installed in the industry sector. In recent years, FGD units for controlling $\mathrm{SO}_{2}$ have been installed at a small number of coal-fired boilers and sintering plants in selected regions. The application of $\mathrm{NO}_{\mathrm{x}}$-control technologies is described in more detail in our previous paper (Zhao et al., 2013c). In contrast with $\mathrm{SO}_{2}$ and $\mathrm{NO}_{\mathrm{x}}$, China has been controlling PM emissions from industrial sources since the late 1980s; the emission standards for industrial sources, however, were updated only gradually until 2010 (see details in Lei et al., 2011). The 11th Five-Year Plan promoted highefficiency FF in some high-emission industries. Most industrial boilers were historically equipped with wet scrubbers (WET) and cyclone dust collectors (CYC), while penetration of high-efficiency FF began recently (Lei et al., 2011; Zhao et al., 2013a). Blast furnaces in China are usually equipped with washing towers and double venturi scrubbers, which have approximately the same removal efficiency as the combination of ESP and WET. Electrostatic precipitators and FF had gradually become the major control technologies applied at 
Table 3. Penetrations of major control technologies in industrial and residential combustion sources in China, Japan, and South Korea (\% of fuel use).

\begin{tabular}{|c|c|c|c|c|c|c|c|c|c|c|c|c|c|c|c|c|c|c|c|c|c|c|}
\hline \multirow[t]{2}{*}{$\begin{array}{l}\text { Energy } \\
\text { technology }\end{array}$} & \multirow{2}{*}{$\begin{array}{l}\begin{array}{l}\text { Control } \\
\text { technology }\end{array} \\
\text { Country }\end{array}$} & \multicolumn{6}{|c|}{ Base year } & \multicolumn{6}{|c|}{ BAU $[0] / \mathrm{PC}[0]$} & \multicolumn{6}{|c|}{$\mathrm{BAU}[1] / \mathrm{PC}[1]$} & \multicolumn{3}{|c|}{$\begin{array}{c}\mathrm{BAU}[2] / \mathrm{PC}[2] \\
2030\end{array}$} \\
\hline & & China & Japan & $\begin{array}{l}\text { South } \\
\text { Korea }\end{array}$ & China & Japan & $\begin{array}{l}\text { South } \\
\text { Korea }\end{array}$ & China & Japan & $\begin{array}{l}\text { South } \\
\text { Korea }\end{array}$ & China & Japan & $\begin{array}{l}\text { South } \\
\text { Korea }\end{array}$ & China & Japan & $\begin{array}{l}\text { South } \\
\text { Korea }\end{array}$ & China & Japan & $\begin{array}{l}\text { South } \\
\text { Korea }\end{array}$ & China & Japan & $\begin{array}{l}\text { South } \\
\text { Korea }\end{array}$ \\
\hline \multirow{7}{*}{$\begin{array}{l}\text { Industrial grate } \\
\text { boilers }\end{array}$} & CYC (PM) & 23 & 0 & 25 & 0 & 0 & 23 & 0 & 0 & 20 & 0 & 0 & 17 & 0 & 0 & 20 & 0 & 0 & 17 & 0 & 0 & 0 \\
\hline & WET (PM) & 73 & 0 & 12 & 95 & 0 & 9 & 95 & 0 & 9 & 95 & 0 & 9 & 60 & 0 & 9 & 20 & 0 & 9 & 0 & 0 & 0 \\
\hline & $\mathrm{ESP}(\mathrm{PM})$ & 0 & 50 & 16 & 0 & 50 & 16 & 0 & 50 & 16 & 0 & 50 & 16 & 20 & 50 & 16 & 40 & 50 & 16 & 0 & 0 & 0 \\
\hline & HED (PM) & 0 & 50 & 47 & 5 & 50 & 52 & 5 & 50 & 55 & 5 & 50 & 58 & 20 & 50 & 55 & 40 & 50 & 58 & 100 & 100 & 100 \\
\hline & $\mathrm{FGD}\left(\mathrm{SO}_{2}\right)$ & 0 & 42 & 80 & 1 & 42 & 85 & 1 & 42 & 88 & 1 & 42 & 90 & 40 & 42 & 88 & 80 & 42 & 90 & 100 & 100 & 100 \\
\hline & $\operatorname{LNB}\left(\mathrm{NO}_{\mathrm{x}}\right)$ & 0 & 65 & 0 & 0 & 80 & 0 & 0 & 80 & 0 & 0 & 80 & 0 & 91 & 80 & 0 & 100 & 80 & 0 & 0 & 0 & 0 \\
\hline & $\begin{array}{l}\mathrm{LNB}+\mathrm{SCR} \\
\left(\mathrm{NO}_{\mathrm{x}}\right)\end{array}$ & 0 & 20 & 0 & 0 & 20 & 0 & 0 & 20 & 0 & 0 & 20 & 0 & 0 & 20 & 0 & 0 & 20 & 0 & 100 & 100 & 100 \\
\hline \multirow{4}{*}{$\begin{array}{l}\text { Residential } \\
\text { boilers }\end{array}$} & CYC (PM) & 23 & 50 & 60 & 14 & 50 & 51 & 12 & 50 & 45 & 10 & 50 & 40 & 0 & 50 & 45 & 0 & 50 & 40 & 0 & 50 & 50 \\
\hline & WET (PM) & 63 & 0 & 40 & 78 & 0 & 49 & 81 & 0 & 55 & 85 & 0 & 60 & 80 & 0 & 55 & 60 & 0 & 60 & 50 & 0 & 0 \\
\hline & HED (PM) & 0 & 50 & 0 & 0 & 50 & 0 & 0 & 50 & 0 & 0 & 50 & 0 & 20 & 50 & 0 & 40 & 50 & 0 & 50 & 50 & 50 \\
\hline & $\mathrm{DC}\left(\mathrm{SO}_{2}\right)$ & 0 & 0 & 0 & 0 & 0 & 0 & 5 & 0 & 0 & 10 & 0 & 0 & 20 & 0 & 0 & 40 & 0 & 0 & 100 & 100 & 100 \\
\hline Coal stoves & STV_ADV_C & 0 & 25 & 10 & 0 & 50 & 13 & 0 & 50 & 18 & 0 & 50 & 20 & 10 & 50 & 18 & 30 & 50 & 20 & 100 & 100 & 100 \\
\hline Biomass & STV_ADV_B & 0 & 35 & 30 & 0 & 48 & 35 & 0 & 70 & 35 & 0 & 78 & 35 & 10 & 70 & 35 & 30 & 78 & 35 & 50 & 50 & 50 \\
\hline stoves & STV_PELL & 0 & 0 & 0 & 0 & 0 & 0 & 0 & 0 & 0 & 0 & 0 & 0 & 0 & 0 & 0 & 0 & 0 & 0 & 50 & 50 & 50 \\
\hline
\end{tabular}

Table 4a. Penetrations of major control technologies for selected industrial process in China $-\mathrm{SO}_{2}$.

\begin{tabular}{|c|c|c|c|c|c|c|c|c|}
\hline \multirow[t]{2}{*}{ Industrial process } & \multirow[t]{2}{*}{ Control technology } & \multicolumn{2}{|c|}{ Base year } & \multicolumn{2}{|c|}{ BAU $[0] / \mathrm{PC}[0]$} & \multicolumn{2}{|c|}{$\mathrm{BAU}[1] / \mathrm{PC}[1]$} & \multirow{2}{*}{$\begin{array}{r}\mathrm{BAU}[2] / \mathrm{PC}[2] \\
2030\end{array}$} \\
\hline & & 2005 & 2010 & 2020 & 2030 & 2020 & 2030 & \\
\hline Sintering & FGD & 0 & 10 & 20 & 40 & 95 & 100 & 100 \\
\hline \multirow[t]{3}{*}{ Coke oven } & $\begin{array}{l}\text { FGD for coal-charging } \\
\text { process }\end{array}$ & 0 & 0 & 0 & 0 & 10 & 10 & 0 \\
\hline & FGD for coke oven gas & 0 & 0 & 0 & 0 & 10 & 10 & 0 \\
\hline & $\begin{array}{l}\text { Combination of the } \\
\text { technologies above }\end{array}$ & 0 & 0 & 0 & 0 & 30 & 50 & 100 \\
\hline Glass production (float process) & FGD & 0 & 0 & 0 & 0 & 50 & 90 & 100 \\
\hline Sulfuric acid production & $\begin{array}{l}\text { Ammonia acid } \\
\text { desulfurization method }\end{array}$ & 0 & 0 & 0 & 0 & 40 & 80 & 100 \\
\hline
\end{tabular}

cement plants, sintering plants, and basic oxygen furnaces by 2010, while large numbers of electric arc furnaces and coke ovens were still equipped with WET (Lei et al., 2011; Zhao et al., 2013a).

The only control measures for NMVOC emissions in China's industry sector are associated with fossil-fuel exploitation and distribution. Emission standards for gasoline distribution released in 2007 require the following: (1) installation of vapor-recovery systems and modified loading techniques (Stage IA control) for loading and unloading operations; (2) improvement in service station tanks (Stage IB control) and installation of vapor-balancing systems between vehicles and service station tanks (Stage II control); (3) installation of internal floating covers (IFC) or secondary seals for newly built or retrofitted storage tanks. These standards were scheduled to be implemented in relatively large cities of key regions (areas defined by the government as environmentally sensitive, including the Greater Beijing region, the Yangtze River Delta, and the Pearl River Delta) from 20082010 onwards, and in relatively large cities in other provinces from 2012-2015 onwards. We estimated that vapor-recycling systems had been installed at about $15 \%$ of all gasoline storage and distribution operations by 2010 (see Table 4 for details).

In Japan, industrial emissions are limited strictly by the Air Pollution Control Act. The thresholds have changed only very slightly since 1995, but are still among the most stringent in the world (Ministry of the Environment of Japan, 2013). Under such strict regulations, the vast majority of blast furnaces, basic oxygen furnaces, electric arc furnaces, and cement kilns are controlled with HEDs. The PM control portfolio for industrial boilers, sintering plants, glass production plants, and coke ovens is typically a mix of ESPs and HEDs. Effective $\mathrm{SO}_{2}$ removal technologies (70$80 \%$ removal efficiency) are applied in various industries, including sintering, cement production, coke ovens, sulfuric acid production, and other industrial processes (GainsAsia model of the International Institute for Applied System Analysis, IIASA, http://gains.iiasa.ac.at/models/). The average efficiency of such removal equipment has increased gradually as old facilities are retired. The dominant controls for $\mathrm{NO}_{\mathrm{x}}$ emissions as of 2010 were low- $\mathrm{NO}_{\mathrm{x}}$ combustion 
Table 4b. Penetrations of major control technologies for selected industrial process in China $-\mathrm{NO}_{\mathrm{x}}$.

\begin{tabular}{llrrrrrrr}
\hline Industrial process & Control technology & \multicolumn{2}{c}{ Base year } & \multicolumn{2}{c}{ BAU[0]/PC[0] } & \multicolumn{2}{c}{ BAU[1]/PC[1] } & BAU[2]/PC[2] \\
& & 2005 & 2010 & 2020 & 2030 & 2020 & 2030 & 2030 \\
\hline Sintering & SNCR & 0 & 0 & 0 & 0 & 36 & 54 & 20 \\
& SCR & 0 & 0 & 0 & 0 & 24 & 36 & 80 \\
\hline Precalciner cement kiln & LNB & 30 & 35 & 35 & 35 & 30 & 25 & 0 \\
& LNB+SNCR & 0 & 0 & 0 & 0 & 30 & 45 & 0 \\
& LNB+SCR & 0 & 0 & 0 & 0 & 20 & 30 & 100 \\
\hline Glass production & OXFL & 0 & 0 & 0 & 0 & 80 & 88 & 70 \\
(float process) & SCR & 0 & 0 & 0 & 0 & 10 & 12 & 30 \\
\hline Nitric acid (dual & ABSP & 10 & 12 & 12 & 12 & 18 & 18 & 18 \\
pressure process) & SCR & 15 & 18 & 18 & 18 & 72 & 82 & 82 \\
& ABSP+SCR & 0 & 0 & 0 & 0 & 0 & 0 & 0 \\
\hline Nitric acid & ABSP & 60 & 63 & 66 & 66 & 5 & 5 & 0 \\
(other process) & SCR & 30 & 32 & 34 & 34 & 15 & 15 & 0 \\
& ABSP+SCR & 0 & 0 & 0 & 0 & 80 & 80 & 100 \\
\hline
\end{tabular}

Notes: ABSP, absorption method; OXFL, oxy-fuel combustion technology.

Table 4c. Penetrations of major control technologies for selected industrial process in China - PM.

\begin{tabular}{|c|c|c|c|c|c|c|c|c|}
\hline \multirow[t]{2}{*}{ Industrial process } & \multirow{2}{*}{$\begin{array}{l}\text { Control } \\
\text { technology }\end{array}$} & \multicolumn{2}{|c|}{ Base year } & \multicolumn{2}{|c|}{$\mathrm{BAU}[0] / \mathrm{PC}[0]$} & \multicolumn{2}{|c|}{$\mathrm{BAU}[1] / \mathrm{PC}[1]$} & \multirow{2}{*}{$\begin{array}{r}\mathrm{BAU}[2] / \mathrm{PC}[2] \\
2030\end{array}$} \\
\hline & & 2005 & 2010 & 2020 & 2030 & 2020 & 2030 & \\
\hline \multirow[t]{4}{*}{ Sintering (flue gas) } & CYC & 5 & 0 & 0 & 0 & 0 & 0 & 0 \\
\hline & WET & 20 & 5 & 0 & 0 & 0 & 0 & 0 \\
\hline & ESP & 65 & 75 & 80 & 80 & 70 & 60 & 0 \\
\hline & HED & 10 & 20 & 20 & 20 & 30 & 40 & 100 \\
\hline \multirow[t]{2}{*}{ Blast furnace (flue gas) } & WET & 100 & 100 & 100 & 100 & 100 & 100 & 100 \\
\hline & ESP & 100 & 100 & 100 & 100 & 100 & 100 & 100 \\
\hline \multirow[t]{2}{*}{ Basic oxygen furnace } & ESP & 40 & 30 & 20 & 20 & 10 & 0 & 0 \\
\hline & HED & 60 & 70 & 80 & 80 & 90 & 100 & 100 \\
\hline \multirow[t]{3}{*}{ Electric arc furnace } & WET & 60 & 30 & 20 & 20 & 0 & 0 & 0 \\
\hline & ESP & 30 & 50 & 50 & 50 & 40 & 20 & 0 \\
\hline & HED & 10 & 20 & 30 & 30 & 60 & 80 & 100 \\
\hline \multirow[t]{2}{*}{ Coke oven } & WET & 100 & 100 & 100 & 100 & 50 & 30 & 0 \\
\hline & HED & 0 & 0 & 0 & 0 & 50 & 70 & 100 \\
\hline \multirow[t]{3}{*}{ Precalciner cement kiln } & WET & 1 & 0 & 0 & 0 & 0 & 0 & 0 \\
\hline & ESP & 52 & 40 & 35 & 30 & 20 & 5 & 0 \\
\hline & HED & 47 & 60 & 65 & 70 & 80 & 95 & 100 \\
\hline \multirow[t]{4}{*}{ Glass production } & CYC & 5 & 0 & 0 & 0 & 0 & 0 & 0 \\
\hline & WET & 25 & 20 & 20 & 20 & 0 & 0 & 0 \\
\hline & ESP & 68 & 75 & 75 & 75 & 85 & 75 & 0 \\
\hline & HED & 3 & 5 & 5 & 5 & 15 & 25 & 100 \\
\hline \multirow[t]{4}{*}{ Brick production } & CYC & 40 & 30 & 30 & 30 & 20 & 0 & 0 \\
\hline & WET & 8 & 20 & 20 & 20 & 40 & 50 & 0 \\
\hline & ESP & 0 & 20 & 20 & 20 & 40 & 50 & 0 \\
\hline & HED & 0 & 0 & 0 & 0 & 0 & 0 & 100 \\
\hline
\end{tabular}

Notes: CMN, common control of fugitive emissions; HIEF, high-efficiency control of fugitive emissions. 
Table 4d. Penetrations of major control technologies for selected industrial process in China - NMVOC.

\begin{tabular}{|c|c|c|c|c|c|c|c|c|}
\hline \multirow[t]{2}{*}{ Industrial process } & \multirow[t]{2}{*}{ Control technology } & \multicolumn{2}{|c|}{ Base year } & \multicolumn{2}{|c|}{ BAU[0]/PC $[0]$} & \multicolumn{2}{|c|}{$\mathrm{BAU}[1] / \mathrm{PC}[1]$} & \multirow{2}{*}{$\begin{array}{r}\mathrm{BAU}[2] / \mathrm{PC}[2] \\
2030\end{array}$} \\
\hline & & 2005 & 2010 & 2020 & 2030 & 2020 & 2030 & \\
\hline \multirow[t]{2}{*}{ Coke oven } & No control & 100 & 100 & 100 & 100 & 55 & 20 & 0 \\
\hline & End of pipe control measures & 0 & 0 & 0 & 0 & 45 & 80 & 100 \\
\hline \multirow[t]{4}{*}{ Refinery } & No control & 100 & 100 & 87 & 80 & 20 & 0 & 0 \\
\hline & $\begin{array}{l}\text { Leak detection and repair } \\
\text { program }\end{array}$ & 0 & 0 & 10 & 15 & 30 & 15 & 0 \\
\hline & $\begin{array}{l}\text { Covers on oil and water } \\
\text { separators }\end{array}$ & 0 & 0 & 3 & 5 & 10 & 5 & 0 \\
\hline & $\begin{array}{l}\text { Combination of the above } \\
\text { options }\end{array}$ & 0 & 0 & 0 & 0 & 40 & 80 & 100 \\
\hline \multirow{4}{*}{$\begin{array}{l}\text { Plant oil } \\
\text { extraction }\end{array}$} & No control & 95 & 90 & 84 & 80 & 20 & 0 & 0 \\
\hline & Activated carbon adsorption & 5 & 10 & 13 & 15 & 50 & 50 & 0 \\
\hline & $\begin{array}{l}\text { Schumacher-type DTDC and } \\
\text { activated carbon adsorption }\end{array}$ & 0 & 0 & 3 & 5 & 25 & 35 & 0 \\
\hline & $\begin{array}{l}\text { Schumacher-type DTDC and } \\
\text { new recovery section }\end{array}$ & 0 & 0 & 0 & 0 & 5 & 15 & 100 \\
\hline \multirow[t]{3}{*}{ Pharmacy } & No control & 100 & 100 & 90 & 85 & 15 & 0 & 0 \\
\hline & $\begin{array}{l}\text { Primary measures and } \\
\text { low-level end-of-pipe measures }\end{array}$ & 0 & 0 & 10 & 15 & 50 & 30 & 0 \\
\hline & $\begin{array}{l}\text { Primary measures and high- } \\
\text { level end-of-pipe measures }\end{array}$ & 0 & 0 & 0 & 0 & 35 & 70 & 100 \\
\hline \multirow[t]{2}{*}{ Gasoline storage } & No control & 100 & 95 & 75 & 60 & 25 & 0 & 0 \\
\hline & $\begin{array}{l}\text { IFC (Internal floating covers or } \\
\text { secondary seals) }\end{array}$ & 0 & 5 & 25 & 40 & 75 & 100 & 100 \\
\hline \multirow{2}{*}{$\begin{array}{l}\text { Gasoline loading } \\
\text { and unloading }\end{array}$} & No control & 100 & 85 & 50 & 50 & 25 & 0 & 0 \\
\hline & $\begin{array}{l}\text { Stage IA (Vapor recovery } \\
\text { systems and modified loading } \\
\text { techniques) }\end{array}$ & 0 & 15 & 50 & 50 & 75 & 100 & 100 \\
\hline \multirow[t]{2}{*}{ Service station } & No control & 100 & 85 & 50 & 50 & 25 & 0 & 0 \\
\hline & $\begin{array}{l}\text { Stage IB }+ \text { Stage II } \\
\text { (Improvement in service station } \\
\text { tank and vapor balancing sys- } \\
\text { tem between a vehicle and ser- } \\
\text { vice station tank) }\end{array}$ & 0 & 15 & 50 & 50 & 75 & 100 & 100 \\
\hline \multirow{2}{*}{$\begin{array}{l}\text { Crude oil storage } \\
\text { and distribution }\end{array}$} & No control & 100 & 100 & 100 & 100 & 75 & 50 & 0 \\
\hline & $\begin{array}{l}\text { IFC }+ \text { Stage IA }+ \text { Stage IB }+ \\
\text { Storage II }\end{array}$ & 0 & 0 & 0 & 0 & 25 & 50 & 100 \\
\hline
\end{tabular}

technologies; flue gas denitrification has not been widespread due to relatively high cost.

Emission standards for industrial sources in South Korea are generally less stringent than those of Japan but more stringent than those of China (Ministry of Environment of South Korea, 2013). In contrast with Japan, the PM control portfolio for cement kilns is an equal mix of ESPs and HEDs; ESPs still dominate PM removal for industrial boilers and sintering machines, and HEDs are not widely applied. Flue gas desulfurization systems were widely applied at some high-emitting sources such as industrial boilers and sintering plants by 2010, with penetrations of 85 and $100 \%$, respectively (NIER, 2010, 2013). Similar to Japan, the dominant control measures for $\mathrm{NO}_{\mathrm{x}}$ emissions were low- $\mathrm{NO}_{\mathrm{x}}$ combustion technologies by 2010 .

\subsubsection{Residential sector}

In the three countries there are only limited regulations addressing residential sources. In Japan, about half of residential and commercial boilers are equipped with HEDs, driven by stringent local government regulations. In South Korea 
and China, dominant control technologies are CYC and WET (Table 3).

Compared with boilers, emissions from small stoves are more difficult to control. In Japan, small incinerators dwindled rapidly in the last decade due to a 2000 regulation designed to mitigate dioxin pollution (Ministry of the Environment of Japan, 2013; Wakamatsu et al., 2013). A previous study found briquette stoves have lower emission factors for $\mathrm{SO}_{2}$ and PM (Lei et al., 2011). We estimate briquette use accounted for 6-7\% of total residential coal consumption in China during 2005-2010 (NBS, 2007, 2008a, b, 2009, 2011a, b). Emissions from small stoves can be further reduced by switching to new technologies, e.g., those using catalyst or non-catalyst inserts and/or primary and secondary air deflectors. These types of improved stoves have been spreading gradually in Japan and Korea (see Table 3).

\subsubsection{Transportation sector}

Since 2000, China has issued a series of emission standards for new vehicles and engines based on the European Union (EU) "Euro" Standards; the implementation years and penetrations of major emission standards are shown in Fig. 1 and Table 5. At the national level, Euro I, II, and III standards began to be put into effect in 2000, 2004, and 2007, respectively. The Euro IV standard for light-duty vehicles was implemented in 2011. The Euro IV standard for heavyduty diesel vehicles was originally planned for implementation in 2010, but was postponed until July 2013 by the MEP due largely to an insufficient supply of low-sulfur fuel (Wu et al., 2012). Megacities including Beijing and Shanghai are subject to greater pressure for regulating vehicle emissions, and are therefore 2-3 years ahead of the national regulation. Recently, the Beijing Environmental Protection Bureau announced enforcement of Euro V in 2012 and Euro VI in 2016. Aside from regulations for new vehicles, emission reductions are also achieved by the controlling of in-use vehicle emissions and improvement of fuel quality (Wang and Hao, 2012).

Japan's emission standards for new vehicles have been among the most stringent in the world. Since the introduction of the first regulation in 1981, the standards have been repeatedly strengthened. For light-duty vehicles, the prevailing emission standards for $\mathrm{NO}_{\mathrm{x}}$ and NMVOC during 2005-2010 (under the "New Long-term Regulation") was comparable to that in US (Tier II), and more stringent than that of the EU (Euro IV) before Euro V took effect in the second half of 2009. A more recent "Post New Long-term Regulation" released in 2009 added a limit for PM comparable to US Tier II, while maintaining the prior limits for other pollutants. For heavy-duty vehicles, Japan's $\mathrm{NO}_{\mathrm{x}}$ emission regulations before 2005 had been stricter than those of Europe and the US (Japan Automobile Manufacturers Association, 2011). During 2005-2010, Japan's prevailing standard was comparable to Euro V (issued in 2008), and between the 2004 and 2007 standards of the US. Since the early 2010s, European, US and Japanese regulatory standards for $\mathrm{NO}_{\mathrm{x}}$ and PM emissions for diesel vehicles have been roughly similar (Ministry of the Environment of Japan, 2013; Delphi Company, 2013a, b).

South Korea has gradually intensified its vehicle emission standards to the level of the US and the EU. In December of 2003, Korea issued new vehicle emission standards corresponding to the level of ultra-low emission vehicles (ULEV) for gasoline vehicles and the levels of Euro IV for diesel vehicles, taking effect in 2007. In 2009, South Korea adopted California's non-methane organic gases (NMOG) fleet average system (FAS) for gasoline-fueled vehicles. The fleet average system enables car manufacturers to have a range of vehicle models with different emissions levels. However, each carmaker's fleet is required to meet a prescribed level of NMOG emissions on average, which has been continuously lowered since 2009, and will approach California's by 2014 (http://transportpolicy.net/). For diesel vehicles, Euro V was introduced starting in September 2009, and the Euro VI standard will be in place by 2014 (Ministry of Environment of South Korea, 2013; Delphi Company, 2013a, b). The penetrations of vehicle emission standards in Japan and South Korea are given in Table 5.

\subsubsection{Solvent use}

The Chinese government has released standards to limit the solvent content of some products, including wood paint, interior wall paint, adhesives for shoe production, decorative adhesives, and printing inks. Driven by these standards, the solvent content of some products has declined, and the penetration of low-solvent products increased during 2005-2010. Table 6 and Supplement Table S2 show the penetrations of major control measures for solvent use; Supplement Table S3 shows the changes in the emission factors of typical sources (especially regulated ones) during 2005-2010. Despite the existing standards, most emissions from solvent use remain uncontrolled in China.

In 2004, Japan's Ministry of Environment set a target to reduce the 2000 NMVOC emission levels $30 \%$ by 2010 using both regulations $(10 \%)$ and voluntary efforts $(20 \%)$, with a focus on emissions from solvent use (Ministry of the Environment of Japan, 2013). The actual reductions are estimated to be higher, but the $\mathrm{O}_{3}$ and $\mathrm{PM}$ concentrations have not declined as expected (Wakamatsu et al., 2013).

South Korea issued concentration limits for stack emissions of NMVOC for coating plants and more recently for gravure printing facilities. For outdoor application of paints, the government reached agreement with producers regarding the development of low solvent products as well as improved application methods to minimize NMVOC emissions (Ministry of Environment of South Korea, 2013). 


\begin{tabular}{|c|c|c|c|c|c|c|c|c|c|c|c|c|c|c|c|c|c|c|c|c|c|c|c|c|c|c|c|c|c|c|c|}
\hline Type & 00 & & & & 04 & 05 & 06 & 0 & 08 & 09 & 10 & & 12 & & & 15 & & 17 & 18 & 19 & 20 & & & 23 & & & 26 & & & & \\
\hline Light duty vehicles & 1 & 1 & 1 & 1 & 1 & 2 & 2 & 2 & 3 & 3 & 3 & 4 & 4 & 4 & 4 & 4 & 4 & 4 & 4 & 4 & 4 & 4 & 4 & 4 & 4 & 4 & 4 & 4 & 4 & 44 & 4 \\
\hline Heavy duty diesel vehicles & & 1 & 1 & 1 & 2 & 2 & 2 & 3 & 3 & 3 & 3 & 3 & 3 & 4 & 4 & 4 & 5 & 5 & 5 & 5 & 5 & 5 & 5 & 5 & 5 & 5 & 5 & 5 & 5 & 5 & 5 \\
\hline Heavy duty gasoline vehicles & & & & 1 & 2 & 2 & 2 & 2 & 2 & 2 & 2 & 2 & 2 & 2 & 2 & 2 & 2 & 2 & 2 & 2 & 2 & 2 & 2 & 2 & 2 & 2 & 2 & 2 & 2 & 2 & 2 \\
\hline Motorcycles (2\&4 strokes) & & & & 1 & 2 & 2 & 2 & 2 & 2 & 3 & 3 & 3 & 3 & 3 & 3 & 3 & 3 & 3 & 3 & 3 & 3 & 3 & 3 & 3 & 3 & 3 & 3 & 3 & 3 & 3 & 3 \\
\hline Tri-wheel \& low-speed goods vehicles & & & & & & & 1 & 2 & 2 & 2 & 2 & 2 & 2 & 2 & 2 & 2 & 2 & 2 & 2 & 2 & 2 & 2 & 2 & 2 & 2 & 2 & 2 & 2 & 2 & 2 & 2 \\
\hline Tractors; agricultural machines & & & & & & & & & 1 & 1 & 2 & 2 & 2 & 2 & 2 & 2 & 2 & 2 & 2 & 2 & 2 & 2 & 2 & 2 & 2 & 2 & 2 & 2 & 2 & 2 & 2 \\
\hline
\end{tabular}

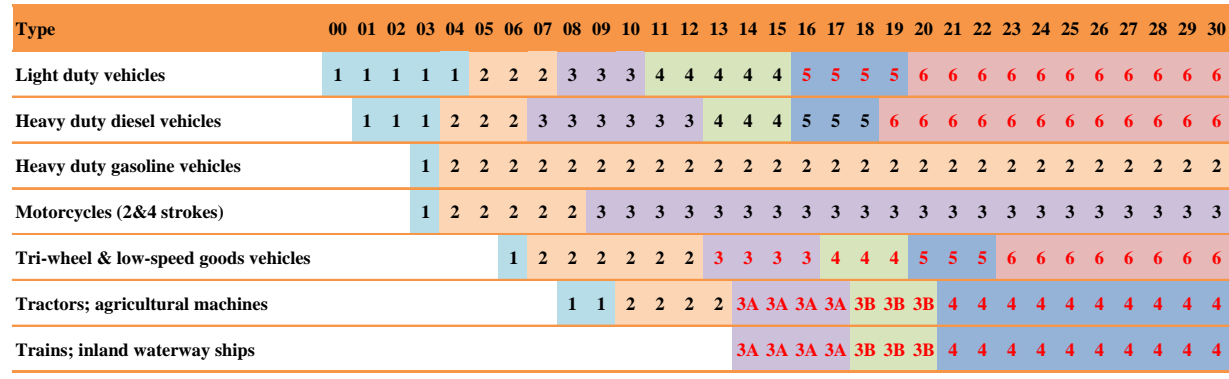

Figure 1. The implementation time of the vehicle emission standards in China: (a) the BAU[0] and PC[0] scenarios; (b) the BAU[1], PC[1], BAU[2], and PC[2] scenarios. The Arabic numbers 1-6 represent Euro I to Euro VI vehicle emission standards. Numbers in black represent standards released by the end of 2010 , and those in red represent those to be released in the future.

\subsection{Effect of control measures on recent emission trends}

The historical emissions of China are estimated using a model structure developed in our previous paper (Zhao et al., 2013c). The emissions from each sector in each province were calculated from data on activities (e.g., energy consumption or industrial production), technology-based uncontrolled emission factors, and penetrations and removal efficiencies of control technologies. The data sources for China are also described in Zhao et al. (2013b).

The historical emissions of Japan are consistent with the JATOP Emission Inventory-Data Base (JEI-DB), developed by the Japan Petroleum Energy Center (JPEC) (JPEC, 2012a, $\mathrm{b}, \mathrm{c})$. Special attention was paid to on-road vehicle emissions. The basic estimation method is to multiply the traffic volume (considering the vehicle type mix) and emission factors for vehicle types. Thee Japan Petroleum Energy Center adjusts that value with correction factors to take account of accumulated mileage, temperature, and humidity. It also includes data from original research on start emission factors, evaporation emission factors, the ratio of high-emission vehicles, and vehicle usage profile from a questionnaire-based survey (JPEC, 2012c). The emissions from other sources were calculated using local statistical information and emission factors, similar to the methodology for the estimation of China's emissions (JPEC, 2012a).

The historical emissions of South Korea were calculated by the National Institute of Environmental Research (NIER), and the data sources are described in its research reports and a web-based database (NIER, 2010, 2013; CAPSS, http: //airemiss.nier.go.kr/). Note that continuous emissions monitoring systems (CEMSs) were installed at most large point sources starting in 2002, allowing CEMS-based emission estimation for 2007-2010, while earlier years were calculated using emission factors. This methodological change produced emission discontinuities in 2007 , leading us to replace pre-2007 emissions from those stacks with values extrapolated from 2007-2010 CEMS-based estimates, taking account of changes of control measures.

The emissions for North Korea, Mongolia, Hong Kong and Macao, and Taiwan are adopted directly from the Gains-Asia model of IIASA (http://gains.iiasa.ac.at/models/).

The national energy consumption and air pollutant emissions are summarized in Table 7 and Table 8, respectively. The sectoral emissions in China are given in Fig. 2, and those in Japan and South Korea are shown in Fig. 3. The provincial emissions in China are shown in Supplement Table S4.

\subsection{1 $\mathrm{NO}_{\mathrm{x}}$}

The total $\mathrm{NO}_{\mathrm{x}}$ emissions in East Asia were 29.7 Mt in 2010 and the growth rate was $25 \%$ during 2005-2010. This trend was dominated by the increase in emissions from China, which contributed $82-88 \%$ of total $\mathrm{NO}_{\mathrm{x}}$ emissions in East Asia.

During this period, $\mathrm{NO}_{\mathrm{x}}$ emissions in China increased by $34 \%$, driven by the rapid increase of industry and transportation. The emissions from power plants stopped growing by 2010 due to the application of LNBs and penetration of non-fossil energy sources in the sector. But emissions from 
Table 5a. Penetrations of vehicle emission standards in China (\%).

\begin{tabular}{|c|c|c|c|c|c|c|c|c|}
\hline \multirow[t]{2}{*}{ Vehicle } & \multirow[t]{2}{*}{ Standard } & \multicolumn{2}{|c|}{ Base year } & \multicolumn{2}{|c|}{ BAU[0]/PC[0] } & \multicolumn{2}{|c|}{ BAU[1]/PC[1] } & \multirow{2}{*}{$\begin{array}{r}\mathrm{BAU}[2] / \mathrm{PC}[2] \\
2030\end{array}$} \\
\hline & & 2005 & 2010 & 2020 & 2030 & 2020 & 2030 & \\
\hline \multirow[t]{7}{*}{ HDT-D } & NOC & 19 & 1 & 0 & 0 & 0 & 0 & 0 \\
\hline & HDEUI & 42 & 8 & 0 & 0 & 0 & 0 & 0 \\
\hline & HDEUII & 39 & 22 & 0 & 0 & 0 & 0 & 0 \\
\hline & HDEUIII & 0 & 70 & 7 & 0 & 7 & 0 & 0 \\
\hline & HDEUIV & 0 & 0 & 19 & 0 & 19 & 0 & 0 \\
\hline & HDEUV & 0 & 0 & 75 & 100 & 41 & 0 & 0 \\
\hline & HDEUVI & 0 & 0 & 0 & 0 & 32 & 100 & 100 \\
\hline \multirow[t]{7}{*}{ HDB-D } & NOC & 28 & 8 & 0 & 0 & 0 & 0 & 0 \\
\hline & HDEUI & 40 & 18 & 0 & 0 & 0 & 0 & 0 \\
\hline & HDEUII & 32 & 24 & 3 & 0 & 3 & 0 & 0 \\
\hline & HDEUIII & 0 & 51 & 20 & 0 & 22 & 0 & 0 \\
\hline & HDEUIV & 0 & 0 & 18 & 2 & 18 & 2 & 0 \\
\hline & HDEUV & 0 & 0 & 59 & 98 & 32 & 8 & 0 \\
\hline & HDEUVI & 0 & 0 & 0 & 0 & 25 & 90 & 100 \\
\hline \multirow[t]{7}{*}{ LDT-D } & NOC & 11 & 0 & 0 & 0 & 0 & 0 & 0 \\
\hline & MDEUI & 65 & 13 & 0 & 0 & 0 & 0 & 0 \\
\hline & MDEUII & 23 & 30 & 0 & 0 & 0 & 0 & 0 \\
\hline & MDEUIII & 0 & 58 & 1 & 0 & 2 & 0 & 0 \\
\hline & MDEUIV & 0 & 0 & 99 & 100 & 26 & 0 & 0 \\
\hline & MDEUV & 0 & 0 & 0 & 0 & 57 & 1 & 0 \\
\hline & MDEUVI & 0 & 0 & 0 & 0 & 16 & 100 & 100 \\
\hline \multirow[t]{7}{*}{ LDT-G } & NOC & 27 & 0 & 0 & 0 & 0 & 0 & 0 \\
\hline & LFEUI & 56 & 13 & 0 & 0 & 0 & 0 & 0 \\
\hline & LFEUII & 16 & 29 & 0 & 0 & 0 & 0 & 0 \\
\hline & LFEUIII & 0 & 58 & 2 & 0 & 2 & 0 & 0 \\
\hline & LFEUIV & 0 & 0 & 98 & 100 & 28 & 0 & 0 \\
\hline & LFEUV & 0 & 0 & 0 & 0 & 56 & 1 & 0 \\
\hline & LFEUVI & 0 & 0 & 0 & 0 & 14 & 99 & 100 \\
\hline \multirow[t]{7}{*}{ LDB-G } & NOC & 31 & 6 & 0 & 0 & 0 & 0 & 0 \\
\hline & LFEUI & 54 & 22 & 1 & 0 & 1 & 0 & 0 \\
\hline & LFEUII & 15 & 23 & 4 & 0 & 4 & 0 & 0 \\
\hline & LFEUIII & 0 & 48 & 14 & 0 & 15 & 0 & 0 \\
\hline & LFEUIV & 0 & 0 & 81 & 100 & 35 & 6 & 0 \\
\hline & LFEUV & 0 & 0 & 0 & 0 & 36 & 25 & 0 \\
\hline & LFEUVI & 0 & 0 & 0 & 0 & 8 & 70 & 100 \\
\hline \multirow[t]{7}{*}{ CAR-G } & NOC & 23 & 3 & 0 & 0 & 0 & 0 & 0 \\
\hline & LFEUI & 55 & 16 & 0 & 0 & 0 & 0 & 0 \\
\hline & LFEUII & 23 & 28 & 3 & 0 & 3 & 0 & 0 \\
\hline & LFEUIII & 0 & 53 & 9 & 0 & 10 & 0 & 0 \\
\hline & LFEUIV & 0 & 0 & 88 & 100 & 30 & 1 & 0 \\
\hline & LFEUV & 0 & 0 & 0 & 0 & 44 & 11 & 0 \\
\hline & LFEUVI & 0 & 0 & 0 & 0 & 13 & 87 & 100 \\
\hline
\end{tabular}

Notes: HDT-D, heavy-duty diesel truck; HDB-D, heavy-duty diesel bus; LDT-D, light-duty diesel truck; LDT-G, light-duty gasoline truck; LDB-G, light-duty gasoline bus; CAR-G, gasoline car; HDEUI $\sim$ HDEUIII, EURO I III standards on heavy-duty diesel road vehicles; MDEUI MDEUIII, EURO I III standards on light-duty diesel road vehicles; LFEUI LFEUIII, EURO I III standards on light-duty spark ignition road vehicles (4-stroke engines).

industry and transportation continued to grow rapidly due to swiftly expanding industrial energy consumption and vehicle populations.

$\mathrm{NO}_{\mathrm{x}}$ emissions from the rest of East Asia decreased by $13 \%$ during the five-year period, mainly attributed to a $21 \%$ reduction in emissions from Japan due chiefly to the imple- mentation of tight emission standards for new vehicles. The emissions of South Korea decreased slightly, by $5 \%$, for the same reason. 
Table 5b. Penetrations of vehicle emission standards in Japan (\%).

\begin{tabular}{|c|c|c|c|c|c|c|c|c|c|c|c|c|c|}
\hline \multirow[t]{2}{*}{ Vehicle } & \multirow[t]{2}{*}{ Standard } & \multicolumn{2}{|c|}{ Base year } & \multicolumn{2}{|c|}{$\begin{array}{c}\text { BAU[0]/BAU[1]/ } \\
\text { PC[0]/PC }[1]\end{array}$} & \multirow{2}{*}{$\begin{array}{r}\mathrm{BAU}[2] / \mathrm{PC}[2] \\
2030\end{array}$} & \multirow[t]{2}{*}{ Vehicle } & \multirow[t]{2}{*}{ Standard } & \multicolumn{2}{|c|}{ Base year } & \multicolumn{2}{|c|}{$\begin{array}{c}\text { BAU[0]/BAU[1]/ } \\
\text { PC[0]/PC }[1]\end{array}$} & \multirow{2}{*}{$\begin{array}{r}\mathrm{BAU}[2] / \mathrm{PC}[2] \\
2030\end{array}$} \\
\hline & & 2005 & 2010 & 2020 & 2030 & & & & 2005 & 2010 & 2020 & 2030 & \\
\hline \multirow[t]{6}{*}{ HDT-D } & BST & $41 \%$ & $25 \%$ & $0 \%$ & $0 \%$ & $0 \%$ & \multirow[t]{7}{*}{ LDT-G } & BST & $38 \%$ & $16 \%$ & $1 \%$ & $0 \%$ & $0 \%$ \\
\hline & ST & $27 \%$ & $19 \%$ & $1 \%$ & $0 \%$ & $0 \%$ & & ST & $4 \%$ & $2 \%$ & $0 \%$ & $0 \%$ & $0 \%$ \\
\hline & LT & $26 \%$ & $25 \%$ & $22 \%$ & $0 \%$ & $0 \%$ & & LT & $10 \%$ & $6 \%$ & $0 \%$ & $0 \%$ & $0 \%$ \\
\hline & NST & $7 \%$ & $11 \%$ & $10 \%$ & $0 \%$ & $0 \%$ & & 1998R & $14 \%$ & $10 \%$ & $6 \%$ & $0 \%$ & $0 \%$ \\
\hline & NLT & $0 \%$ & $20 \%$ & $22 \%$ & $7 \%$ & $0 \%$ & & NST & $34 \%$ & $31 \%$ & $19 \%$ & $0 \%$ & $0 \%$ \\
\hline & PNLT & $0 \%$ & $0 \%$ & $44 \%$ & $93 \%$ & $100 \%$ & & NLT & $0 \%$ & $34 \%$ & $24 \%$ & $8 \%$ & $0 \%$ \\
\hline \multirow[t]{6}{*}{ HDB-D } & BST & $52 \%$ & $32 \%$ & $0 \%$ & $0 \%$ & $0 \%$ & & PNLT & $0 \%$ & $0 \%$ & $49 \%$ & $92 \%$ & $100 \%$ \\
\hline & ST & $19 \%$ & $15 \%$ & $2 \%$ & $0 \%$ & $0 \%$ & \multirow{7}{*}{ LDB-B } & BST & $12 \%$ & $4 \%$ & $0 \%$ & $0 \%$ & $0 \%$ \\
\hline & $\mathrm{LT}$ & $25 \%$ & $24 \%$ & $23 \%$ & $0 \%$ & $0 \%$ & & ST & $4 \%$ & $1 \%$ & $0 \%$ & $0 \%$ & $0 \%$ \\
\hline & NST & $5 \%$ & $8 \%$ & $8 \%$ & $0 \%$ & $0 \%$ & & LT & $4 \%$ & $1 \%$ & $0 \%$ & $0 \%$ & $0 \%$ \\
\hline & NLT & $0 \%$ & $20 \%$ & $22 \%$ & $8 \%$ & $0 \%$ & & 1998R & $16 \%$ & $6 \%$ & $3 \%$ & $0 \%$ & $0 \%$ \\
\hline & PNLT & $0 \%$ & $0 \%$ & $45 \%$ & $92 \%$ & $100 \%$ & & NST & $63 \%$ & $35 \%$ & $17 \%$ & $0 \%$ & $0 \%$ \\
\hline \multirow[t]{6}{*}{ LDT-D } & BST & $41 \%$ & $27 \%$ & $0 \%$ & $0 \%$ & $0 \%$ & & NLT & $0 \%$ & $52 \%$ & $27 \%$ & $10 \%$ & $0 \%$ \\
\hline & ST & $27 \%$ & $20 \%$ & $0 \%$ & $0 \%$ & $0 \%$ & & PNLT & $0 \%$ & $0 \%$ & $53 \%$ & $90 \%$ & $100 \%$ \\
\hline & LT & $27 \%$ & $23 \%$ & $22 \%$ & $0 \%$ & $0 \%$ & \multirow[t]{4}{*}{ CAR } & 1983R & $72 \%$ & $32 \%$ & $8 \%$ & $0 \%$ & $0 \%$ \\
\hline & NST & $5 \%$ & $11 \%$ & $10 \%$ & $0 \%$ & $0 \%$ & & NST & $28 \%$ & $37 \%$ & $24 \%$ & $0 \%$ & $0 \%$ \\
\hline & NLT & $0 \%$ & $20 \%$ & $23 \%$ & $7 \%$ & $0 \%$ & & NLT & $0 \%$ & $31 \%$ & $23 \%$ & $9 \%$ & $0 \%$ \\
\hline & PNLT & $0 \%$ & $0 \%$ & $46 \%$ & $93 \%$ & $100 \%$ & & PNLT & $0 \%$ & $0 \%$ & $46 \%$ & $91 \%$ & $100 \%$ \\
\hline
\end{tabular}

Notes: BST, before short term target; ST, short term target; LT, long term target; NST, new short-term target; NLT, new long-term target; PNLT, post new long-term target; 1998R, 1998 regulation; $1983 \mathrm{R}, 1983$ regulation.

Table 5c. Penetrations of vehicle emission standards in South Korea (\%).

\begin{tabular}{|c|c|c|c|c|c|c|c|c|c|c|c|c|c|}
\hline \multirow[t]{2}{*}{ Vehicle } & \multirow[t]{2}{*}{ Standard } & \multicolumn{2}{|c|}{ Base year } & \multicolumn{2}{|c|}{$\begin{array}{c}\text { BAU[0]/BAU[1]/ } \\
\text { PC[0]/PC }[1]\end{array}$} & \multirow{2}{*}{$\begin{array}{r}\mathrm{BAU}[2] / \mathrm{PC}[2] \\
2030\end{array}$} & \multirow[t]{2}{*}{ Vehicle } & \multirow[t]{2}{*}{ Standard } & \multicolumn{2}{|c|}{ Base year } & \multicolumn{2}{|c|}{$\begin{array}{c}\text { BAU[0]/BAU[1]/ } \\
\text { PC[0]/PC }[1]\end{array}$} & \multirow{2}{*}{$\begin{array}{r}\mathrm{BAU}[2] / \mathrm{PC}[2] \\
2030\end{array}$} \\
\hline & & 2005 & 2010 & 2020 & 2030 & & & & 2005 & 2010 & 2020 & 2030 & \\
\hline \multirow[t]{7}{*}{ HDT-D } & NOC & 0 & 0 & 0 & 0 & 0 & \multirow[t]{7}{*}{ LDT-G } & NOC & 0 & 0 & 0 & 0 & 0 \\
\hline & HDEUI & 13 & 10 & 0 & 0 & 0 & & LFEUI & 15 & 10 & 0 & 0 & 0 \\
\hline & HDEUII & 15 & 13 & 0 & 0 & 0 & & LFEUII & 33 & 12 & 0 & 0 & 0 \\
\hline & HDEUIII & 35 & 33 & 0 & 0 & 0 & & LFEUIII & 30 & 28 & 0 & 0 & 0 \\
\hline & HDEUIV & 0 & 24 & 10 & 0 & 0 & & LFEUIV & 7 & 38 & 23 & 0 & 0 \\
\hline & HDEUV & 0 & 12 & 48 & 0 & 0 & & LFEUV & 0 & 10 & 77 & 100 & 0 \\
\hline & HDEUVI & 0 & 0 & 42 & 100 & 100 & & LFEUVI & 0 & 0 & 0 & 0 & 100 \\
\hline \multirow[t]{7}{*}{ HDB-D } & NOC & 0 & 0 & 0 & 0 & 0 & \multirow{7}{*}{ LDB-G } & NOC & 0 & 0 & 0 & 0 & 0 \\
\hline & HDEUI & 13 & 10 & 0 & 0 & 0 & & LFEUI & 15 & 10 & 0 & 0 & 0 \\
\hline & HDEUII & 15 & 13 & 0 & 0 & 0 & & LFEUII & 33 & 12 & 0 & 0 & 0 \\
\hline & HDEUIII & 35 & 33 & 0 & 0 & 0 & & LFEUIII & 30 & 28 & 0 & 0 & 0 \\
\hline & HDEUIV & 0 & 24 & 10 & 0 & 0 & & LFEUIV & 7 & 38 & 23 & 0 & 0 \\
\hline & HDEUV & 0 & 12 & 48 & 0 & 0 & & LFEUV & 0 & 10 & 77 & 100 & 0 \\
\hline & HDEUVI & 0 & 0 & 42 & 100 & 100 & & LFEUVI & 0 & 0 & 0 & 0 & 100 \\
\hline \multirow[t]{7}{*}{ LDT-D } & NOC & 0 & 0 & 0 & 0 & 0 & \multirow[t]{7}{*}{ CAR-G } & NOC & 0 & 0 & 0 & 0 & 0 \\
\hline & MDEUI & 30 & 10 & 0 & 0 & 0 & & LFEUI & 15 & 10 & 0 & 0 & 0 \\
\hline & MDEUII & 20 & 17 & 0 & 0 & 0 & & LFEUII & 33 & 12 & 0 & 0 & 0 \\
\hline & MDEUIII & 35 & 34 & 0 & 0 & 0 & & LFEUIII & 30 & 28 & 0 & 0 & 0 \\
\hline & MDEUIV & 0 & 27 & 25 & 0 & 0 & & LFEUIV & 7 & 38 & 23 & 0 & 0 \\
\hline & MDEUV & 0 & 8 & 35 & 0 & 0 & & LFEUV & 0 & 10 & 77 & 100 & 0 \\
\hline & MDEUVI & 0 & 0 & 40 & 100 & 100 & & LFEUVI & 0 & 0 & 0 & 0 & 100 \\
\hline
\end{tabular}

Note: South Korea adopted US emission standards for gasoline vehicles, which were equivalent to the penetrations of European standards above in terms of removal efficiencies.

\subsection{2 $\quad \mathrm{SO}_{2}$}

The total $\mathrm{SO}_{2}$ emissions in East Asia decreased by $15 \%$, from $30.4 \mathrm{Mt}$ in 2005 to $25.9 \mathrm{Mt}$ in 2010 , with both China and the rest of East Asia experiencing the same $15 \%$ rate of decline and Chinese emissions accounting for as much as $94 \%$ of the regional total.
The decline in China's $\mathrm{SO}_{2}$ emissions is mainly attributable to the widespread deployment of FGD at power plants, even as emissions from China's industrial sector continued to rise during this period; this is consistent with the recent estimates by Zhang et al. (2012b), Lu et al. (2011), Klimont et al. (2013).

$\mathrm{SO}_{2}$ emissions of Japan decreased by $20 \%$, mainly attributed to the increasing penetration of higher-efficiency desulfurization technologies in the industrial sector, and the 

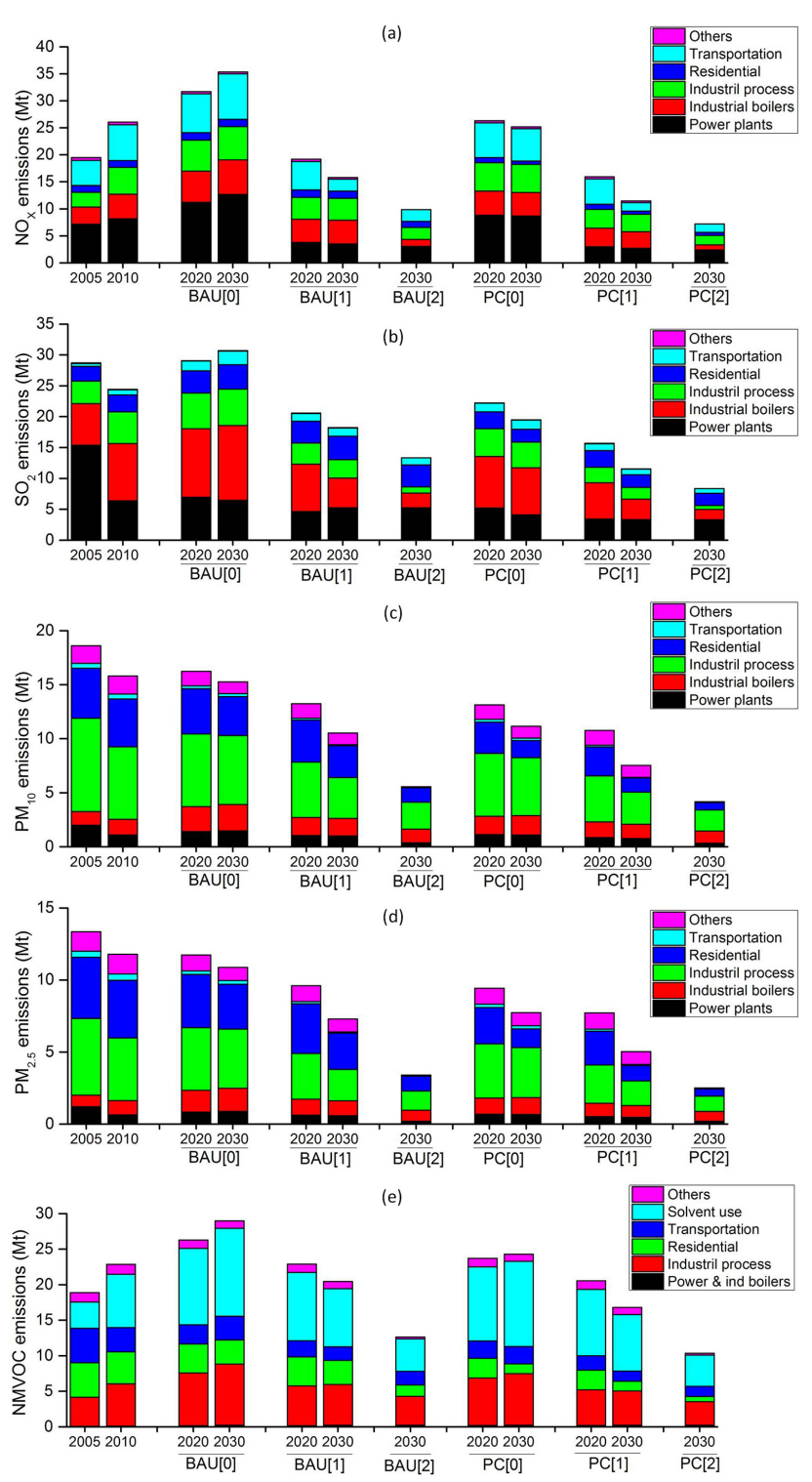

Figure 2. Emissions of major air pollutants in China and their sectoral distribution during 2005-2030: (a) $\mathrm{NO}_{\mathrm{x}}$; (b) $\mathrm{SO}_{2}$; (c) $\mathrm{PM}_{10}$; (d) $\mathrm{PM}_{2.5}$; (e) NMVOC. The sector of "Others" represents open biomass burning for $\mathrm{NO}_{\mathrm{x}}, \mathrm{SO}_{2}, \mathrm{PM}_{10}$, and $\mathrm{PM}_{2.5}$; for $\mathrm{NMVOC}$, it includes open biomass burning, waste treatment, cooking, and smoking, with open biomass burning contributing over $80 \%$ of the total NMVOC emissions of this sector.

replacement of coal and oil with cleaner energy sources. South Korea's $\mathrm{SO}_{2}$ emissions remained roughly constant, because the reduction of the emissions from power plants (due to the deployment of FGD) was offset by the increasing emissions from industrial sources.

\subsection{3 $\quad \mathrm{PM}_{10}$ and $\mathrm{PM}_{2.5}$}

In 2010, the total $\mathrm{PM}_{10}$ and $\mathrm{PM}_{2.5}$ emissions in East Asia were 16.8 and $12.5 \mathrm{Mt}$, respectively, decreasing $15 \%$ and $12 \%$ from 2005 levels. This trend was also dominated by emission trends in China, as its $\mathrm{PM}_{10}$ and $\mathrm{PM}_{2.5}$ emissions represent about $94 \%$ of those of East Asia.

China's $\mathrm{PM}_{10}$ and $\mathrm{PM}_{2.5}$ emissions decreased by 15 and $12 \%$, respectively, during the five years. We estimate that emissions of power plants and the cement industry experienced the greatest decrease (43-47\% during 2005-2010), a result of the rapid evolution of end-of-pipe controls (see Table 2 and Table 4). The emissions of industrial boilers and steel industry increased by $14-32 \%$, while the emissions of other sectors remained relatively stable.

$\mathrm{PM}_{10}$ and $\mathrm{PM}_{2.5}$ emissions decreased by 7 and $9 \%$ in the rest of East Asia. The reduction rate was as large as 19-28\% in Japan, with the transportation sector contributing $70 \%$ of this decline. Emissions from South Korea increased somewhat due to the increase in industrial fuel consumption and the relatively stable energy intensity of the industrial sector (see Sect. 2.1.2).

\subsubsection{NMVOC}

The total NMVOC emissions in East Asia were 25.9 Mt in 2010, reflecting $15 \%$ growth over 2005 levels, an integrated effect of a $21 \%$ increase in emissions from China (contributing $84-88 \%$ of the total emissions) and a $17 \%$ reduction in emissions from other countries.

In China, the NMVOC emissions from transportation and residential combustion decreased due to improved vehicle emission standards and the replacement of biomass with cleaner energy sources. However, these reductions were more than offset by the dramatic increase of emissions from industrial processes $(+46 \%)$ and solvent use $(+102 \%)$.

Japan's NMVOC emissions decreased by $30 \%$, mainly attributed to the government's efforts to reduce the emissions from solvent use and the implementation of stringent vehicle emission standards. In South Korea, although the enhancement of vehicle emission standards lowered NMVOC emissions from transportation, the emissions from solvent use increased even more rapidly, leading to a $15 \%$ increase in total NMVOC emissions.

\subsection{Uncertainty analysis}

A Monte Carlo uncertainty analysis was performed on the emission inventories of East Asia for 2005-2010, following the methodology described in Bo et al. (2008) and Wei et al. (2008, 2011a). The probability distribution of the activity data and emission factors were determined using the method and data used in Wei et al. $(2008,2011 a)$ as a starting point. We re-evaluated the uncertainties of the emission factors taking account of new field measurements in recent years. 
Specifically, we assumed that the uncertainties of the activity data and emission factors had lognormal distributions. The uncertainties of activity levels were rated from level I to level $\mathrm{V}$, corresponding to coefficients of variation $(\mathrm{CVs}$, defined as the ratio of the standard deviation to the mean of a probability distribution, indicating the extent of variability in relation to the mean of the population) of $\pm 30 \%, \pm 80 \%$, $\pm 100 \%, \pm 150 \%$, and $\pm 300 \%$, respectively. For example, the activity levels derived directly from statistics were rated as level I, and those calculated using nonstatistical data and empirical conversion factors were rated as level V. The uncertainties of emission factors were also rated from level I to level V, with the corresponding CVs of $\pm 50 \%, \pm 80 \%$, $\pm 150 \%, \pm 300 \%$, and $\pm 500 \%$, respectively. The emission factors for the sources with stable emission rates and over 10 local field measurements were rated as level I, while a rating of level V was assigned when the emission factors for similar sources were applied due to the lack of measurements. With the determined probability distribution of the activity data and emission factors of each source, the Monte Carlo method was used to propagate these uncertainties into an uncertainty for the total inventory. Table S5 shows the calculated uncertainties by sector.

During 2005-2010, the average $90 \%$ confidence interval of the total $\mathrm{NO}_{\mathrm{x}}$ emissions is $[-31 \%, 44 \%]$. The $\mathrm{CV}$ is $\pm 25 \%$ on average. The uncertainties of emissions vary with emission sectors (see Supplement Table S5), attributable to the different magnitudes of uncertainties associated with activity levels and emission factors. Open biomass burning has the largest CV ( $\pm 177 \%)$ because both the activity levels and the emission factors are quite uncertain. The transportation sector has the second highest uncertainty $(\mathrm{CV}= \pm 66 \%)$, as its fuel consumption is calculated from vehicle population, annual average mileage traveled, and fuel economy, rather than from energy statistics.

The average $90 \%$ confidence interval and $\mathrm{CV}$ of the total $\mathrm{SO}_{2}$ emissions are $[-29 \%, 45 \%]$ and $\pm 28 \%$, respectively, during 2005-2010. Similar to that of $\mathrm{NO}_{\mathrm{x}}$ emissions, the $\mathrm{SO}_{2}$ emissions from open biomass burning have the highest uncertainty $(\mathrm{CV}= \pm 179 \%)$. The uncertainties of the industrial, residential, and transportation sectors are quite close to each other, with CVs in the range of $\pm 48- \pm 51 \%$.

During 2005-2010, the average $90 \%$ confidence interval and $\mathrm{CV}$ of the total $\mathrm{PM}_{2.5}$ emissions are $[-39 \%, 49 \%]$ and $\pm 39 \%$, respectively. Open biomass burning is the sector subject to the highest uncertainty $(\mathrm{CV}= \pm 216 \%)$. The residential sector has the second highest uncertainty due to the relatively few emission factor measurements for coal stoves and biomass stoves, the dominant $\mathrm{PM}_{2.5}$ emission sources of this sector.

The average $90 \%$ confidence interval and CV of the total NMVOC emissions are $[-42 \%, 67 \%]$ and $\pm 42 \%$, respectively. The "other sectors", which include open biomass burning (contributing over $80 \%$ of NMVOC emissions in this category), waste treatment, cooking, and smoking, have the highest uncertainty $(\mathrm{CV}= \pm 184 \%)$. This is followed by solvent use $(\mathrm{CV}= \pm 78 \%)$, for which the activity levels are not directly available from official statistics and emission factor measurements are lacking. The CVs for the industrial, residential, and transportation sectors are all within the range of $\pm 57- \pm 65 \%$.

It can be seen that NMVOC is the pollutant subject to the highest uncertainty, followed by $\mathrm{PM}_{2.5}$. The high uncertainty of NMVOC emissions is mainly attributable to the lack of local measurements for many industrial and solvent use sources. The higher uncertainties of $\mathrm{PM}_{2.5}$ emissions compared with $\mathrm{NO}_{\mathrm{x}}$ and $\mathrm{SO}_{2}$ result from the larger uncertainties in the emission factors (e.g., uncertainties in the emission factors of industrial fugitive dust and in the removal efficiencies of dust collectors), and a relatively large share of emissions from small-scale emission sources (e.g., coal stoves and biomass stoves).

\section{Future emission scenarios for air pollutants}

To quantify the effects of various measures on future air pollutant emissions, in this study we developed emission scenarios for $\mathrm{SO}_{2}, \mathrm{NO}_{\mathrm{x}}, \mathrm{PM}$, and NMVOC based on energysaving policies and end-of-pipe control strategies. The scenarios are developed with the same model structure as that used for the estimation of historical emissions developed in our previous paper (Zhao et al., 2013c). The energy service demand is estimated based on driving forces (e.g., GDP and population). The future technology distribution and energy efficiencies are assumed and the energy consumption is calculated accordingly. Both historical and future emissions are derived from energy consumption, emission factors, and assumptions on the penetration of control technologies. For details, see Zhao et al. (2013c).

We developed two energy scenarios, a business-as-usual scenario (BAU) and an alternative policy scenario (PC). The BAU scenario is based on current regulations and implementation status (as of the end of 2010). In the PC scenario, we assume the introduction and strict enforcement of new energy-saving policies, including ones leading to a more energy-conserving lifestyle, structural adjustment, and energy efficiency improvement. Energy-conserving lifestyle is defined by a slower growth of energy service demand that would result from less building area, a smaller vehicle population, and reduced consumption of energy-intensive industrial products, electricity, and heat. Structural adjustment includes promotion of clean and renewable fuels and energyefficient technologies. Examples include renewable energy sources and combined heat and power (CHP) for power plants and heat supply, arc furnaces and large precalciner kilns for the industrial sector, biogas stoves and heat pumps for the residential sector, and electric and biofuel vehicles for the transportation sector. Energy efficiency improvement 
refers to the improvement of the energy efficiencies of individual technologies.

We developed three end-of-pipe control strategies for each energy scenario, including baseline (abbreviated as [0]), progressive [1], and maximum feasible control [2], thereby constituting six emission scenarios (BAU[0], BAU[1], BAU[2], $\mathrm{PC}[0], \mathrm{PC}[1]$, and $\mathrm{PC}[2])$. The baseline control strategy [0] assumes that all current pollution control regulations (as of the end of 2010) and the current implementation status would be followed during 2011-2030. Control strategy [1] assumes that new pollution control policies would be released and implemented in China, representing a progressive approach towards future environmental policies. For other countries, we assume the same controls as strategy [0]. Control strategy [2] assumes that technically feasible control technologies would be fully applied by 2030 , regardless of the economic cost. The definition of the energy scenarios and emission scenarios are summarized in Table 1.

In this paper we focus on the development of energy scenarios and emission scenarios for China. The scenarios for other countries are adapted from those developed by IIASA in a project funded by United Nations Environment Programme (UNEP) and World Meteorological Organization (WMO) (Shindell et al., 2012; UNEP and WMO, 2011). Both the energy consumption and air pollutant emissions were calculated with a five-year time step, although the parameters and results are presented for selected years only. Detailed assumptions of the energy scenarios and emission scenarios are documented below.

\subsection{Development of energy scenarios}

For countries other than China, our BAU and PC scenarios are consistent with the energy pathways of the reference and $450 \mathrm{ppm}$ scenarios in Shindell et al. (2012) and in UNEP and WMO (2011), which were based on the reference and $450 \mathrm{ppm}$ scenarios presented in the World Energy Outlook 2009 (IEA, 2009), respectively. While the reference scenario is based on current energy and climate-related policies, the $450 \mathrm{ppm}$ scenario explores the global energy consumption if countries take coordinated action to restrict the global temperature increase to $2^{\circ} \mathrm{C}$. The details of energy scenarios are described in Shindell et al. (2012), UNEP and WMO (2011) and IEA (2009).

For China, we have developed two energy scenarios that are consistent with our previous paper (Zhao et al., 2013c). Presented below is a brief description of the assumptions and results of the energy scenarios; see Zhao et al. (2013c) for detailed information. Note that because that paper focused on the emission trends of $\mathrm{NO}_{\mathrm{x}}$, it did not project activity data in terms of fossil fuel distribution (included in the industrial sector for this study) nor the use of solvents. These two projections are incorporated below.

We assume that the annual average GDP growth rate will decrease gradually from $8.0 \%$ during $2011-2015$ to $5.5 \%$ during 2026-2030. The national population is projected to increase from 1.34 billion in 2010 to 1.44 billion in 2020 and 1.47 billion in 2030, and the urbanization rate (proportion of people in urban areas) is assumed to increase from $49.95 \%$ in 2010 to 58 and $63 \%$ in 2020 and 2030, respectively.

The total electricity production is projected to be $10-12 \%$ lower in the PC scenario than that of the BAU scenario. The PC scenario considers aggressive development plans for clean and renewable energy power generation; therefore, the proportion of electricity production from coal-fired power plants is expected to decrease to $57 \%$ in 2030 in the PC scenario, contrasted with $73 \%$ in the BAU scenario.

We applied an elasticity coefficient method for the estimation of future production of industrial products, the governing equation of which is as follows:

$Y_{t 1}=Y_{t 0}\left(\frac{\mathrm{d} v_{t 1}}{\mathrm{~d} v_{t 0}}\right)^{\delta}$

where, $t 0, t 1$ are time periods, e.g., $t 0=2010$, and $t 1=$ 2030; $Y$ is the yield of a specific industrial product; $\mathrm{d} v$ is the driving force, namely sectoral value added or population; and $\delta$ is the product-specific elasticity coefficient. The values of $\delta$ are determined through (1) historical trends during 1995-2010; (2) the experience of developed countries; and (3) projections of industrial associations. Generally speaking, production of most energy-intensive commodities used in construction of infrastructure are expected to increase until 2020, and then to stabilize or even decline after 2020, whereas products associated with household consumption are expected to increase through 2030, although at a declining rate. We projected lower production of industrial products in the PC scenario than those of the BAU scenario because of more energy-conserving lifestyles. The penetrations of less energy-intensive technologies are assumed to be higher in the PC scenario than the BAU scenario.

For the residential sector, China's building area per capita in the PC scenario is expected to be $3-4 \mathrm{~m}^{2}$ lower than that of the BAU scenario in both urban and rural areas. The heating energy demand per unit area is somewhat lower in our PC scenario because of the implementation of new energyconservation standards in the design of buildings. Replacement of coal and direct biomass burning with clean fuels are assumed in both urban and rural areas, with faster progress in the PC scenario.

The vehicle population per 1000 persons is projected at 380 and 325 in the BAU and PC scenarios, respectively. The PC scenario also assumes aggressive promotion of electric vehicles, and a progressive implementation of new fuel efficiency standards, resulting in 33 and $57 \%$ improvement in the fuel economy of new passenger cars and new heavy-duty vehicles by 2030 .

The increase of fossil fuels stored and distributed is expected to be consistent with the increase of total fuel consumption in the future. The gasoline or diesel sold at service 
stations is expected to have the same growth rate as fuel consumption in the transportation sector. Therefore, the activity levels of fossil fuel distribution are derived from the projections of fuel consumption.

The activity data for the solvent use sector are the consumption of products containing solvents. The forecast approach, which is consistent with Wei et al. (2011b), is illustrated as follows:

$A_{t 1}=\sum_{j}\left(A_{t 0, j} \times \frac{Y_{t 1, j}}{Y_{t 0, j}}\right)$

where, $t 0, t 1$ are time periods, e.g., $t 0=2010$, and $t 1=$ 2030; $j$ represents the industries using a specific solvent product; $A_{t 1}$ is the consumption of this solvent product in the year $t 1 ; A_{t 0, j}$ is the consumption of this solvent product in industry $j$ in the year $t 0 ; Y_{t 0, j}$ and $Y_{t 1, j}$ are the yields of the major products (e.g., crude steel for the iron and steel industry) for industry $j$ in the year $t 0$ and $t 1$, respectively. The yields of industrial products were projected using the elasticity coefficient method as described above.

Table 7 shows current and future energy consumption in East Asia. Total energy consumption in East Asia was $123 \mathrm{EJ}$ in 2005 and $161 \mathrm{EJ}$ in 2010. The energy consumption of China accounts for $69-76 \%$ of the total energy amount during 2005-2010, followed by 13-18\% for Japan, and about $7 \%$ for South Korea. By 2030, the total energy consumption is projected to increase to $243 \mathrm{EJ}$ under the BAU scenario and to $195 \mathrm{EJ}$ under the PC scenario, 51 and $21 \%$ higher than that of 2010.

Of all the countries, China is expected to experience the fastest growth rate in energy consumption. By 2030, China's energy consumption is projected to increase by 64 and $27 \%$ from the 2010 level in BAU and PC scenarios, respectively. Industry fuel consumption is expected to increase notably slower than the total fuel use in both scenarios, resulting from the structural economic adjustment. In contrast, the energy consumption of transportation is projected to increase dramatically by 200 and $101 \%$ in the BAU and PC scenarios, respectively, measured in 2030 against the 2010 levels, driven by the swift increase in vehicle population. The growth rate of energy consumption in other sectors is close to that of the total amount. Because of the energy-saving measures, the energy consumption of power plants, industry, residential, and transportation sectors in the PC scenario are 18, 19, 27, and $33 \%$ lower than the BAU scenario, respectively. Coal continues to dominate China's energy mix, but the proportion decreases from $68 \%$ in 2010 to 60 and $52 \%$ in 2030 under the BAU and PC scenarios, respectively. In contrast, the shares of natural gas and "other renewable energy and nuclear energy" are estimated to increase from 3.4 and $7.5 \%$ in 2010 to 5.5 and $8.9 \%$ in 2030 under the BAU scenario, and 9.3 and $15.8 \%$ under the PC scenario, respectively.

We assume a ban of open biomass burning in the BAU[2]/PC[2] scenarios.

\subsection{Future emission trends and effects of control measures}

The air pollutant emissions in each scenario are estimated based on the assumptions in Sects. 3.1 and Sect. 3.2. Table 8 shows the national air pollutant emissions in East Asia under each scenario. Figure 2 shows the emissions by sector in China, and Fig. 3 shows the emissions by sector in Japan and South Korea. Supplement Table S4 shows the provincial emissions in China.

\subsection{1 $\mathrm{NO}_{\mathrm{x}}$}

Under current regulations and implementation status (the BAU[0] scenario), $\mathrm{NO}_{\mathrm{x}}$ emissions in East Asia are projected to increase by $28 \%$ in 2030 from the 2010 levels. The implementation of assumed energy-saving measures (reflected by the difference between the BAU[0] and the PC[0] scenarios) and progressive end-of-pipe control measures (reflected by the difference between the $\mathrm{PC}[0]$ and the PC[1] scenarios) are expected to reduce $\mathrm{NO}_{\mathrm{x}}$ emissions by 28 and $36 \%$, respectively, from the baseline projection (the BAU[0] scenario). With the full enforcement of technically feasible control measures (the PC[2] scenario), the remaining emissions account for only $21 \%$ of the baseline projection, or $27 \%$ of the 2010 levels.

China's emission growth potential under current regulations $(36 \%)$ is significantly larger than the average of East Asia (28\%), resulting from a great increase in energy consumption and weak existing control measures. China's share in East Asia's $\mathrm{NO}_{\mathrm{x}}$ emissions would increase to $93 \%$ under the baseline projection. The enforcement of energy-saving measures (the $\mathrm{PC}[0]$ scenario) leads to a $29 \%$ reduction from the baseline projection. With the implementation of the 12th Five-Year Plan and slowly strengthened end-of-pipe control policies after 2015 (reflected by the difference between the $\mathrm{PC}[0]$ and the $\mathrm{PC}[1]$ scenarios), China's $\mathrm{NO}_{\mathrm{x}}$ emissions could be reduced by nearly $40 \%$ (compared to the baseline projection). The most effective control measures are the installation of SCR and SNCR and the application of stringent vehicle standards, which together achieve nearly $80 \%$ of this reduction. The full application of technically feasible control measures (the PC[2] scenario) could reduce China's $\mathrm{NO}_{\mathrm{x}}$ emissions to $20 \%$ of the baseline projection, or $28 \%$ of the 2010 levels. It should be noted that the $\mathrm{NO}_{\mathrm{x}}$ emissions are projected at $22.9 \mathrm{Mt}$ in 2015 under the BAU[1] scenario, $12.2 \%$ lower than that of 2010. This implies that if the control policies in the 12th Five-Year Plan can be implemented successfully (as assumed in the BAU[1] scenario), the national target to reduce the $\mathrm{NO}_{\mathrm{x}}$ emissions by $10 \%$ during 2011-2015 would be achieved.

By 2030, the energy consumption of East Asia other than China is projected to increase slightly by 12 and $2 \%$ over the 2010 level in the BAU and PC scenarios, respectively. Under current policies, Japan's energy consumption is projected to 
Table 6. Penetrations of major control technologies for NMVOC emissions from selected solvent use types in China.

\begin{tabular}{|c|c|c|c|c|c|c|c|c|}
\hline \multirow[t]{2}{*}{ Solvent use type } & \multirow[t]{2}{*}{ Control technology } & \multicolumn{2}{|c|}{ Base year } & \multicolumn{2}{|c|}{ BAU[0]/PC[0] } & \multicolumn{2}{|c|}{$\mathrm{BAU}[1] / \mathrm{PC}[1]$} & \multirow{2}{*}{$\begin{array}{r}\mathrm{BAU}[2] / \mathrm{PC}[2] \\
2030\end{array}$} \\
\hline & & 2005 & 2010 & 2020 & 2030 & 2020 & 2030 & \\
\hline \multirow{4}{*}{$\begin{array}{l}\text { Paint use in interior } \\
\text { walls of buildings }\end{array}$} & No control (GB18582-2001) & 100 & 0 & 0 & 0 & 0 & 0 & 0 \\
\hline & $\begin{array}{l}\text { Decrease of solvent } \\
\text { content-GB18582-2008 }\end{array}$ & 0 & 100 & 95 & 90 & 70 & 0 & 0 \\
\hline & $\begin{array}{l}\text { Decrease of solvent } \\
\text { content }-2004 / 42 / \text { EC stage } 1\end{array}$ & 0 & 0 & 5 & 10 & 30 & 80 & 0 \\
\hline & $\begin{array}{l}\text { Decrease of solvent } \\
\text { content }-2004 / 42 / \text { EC stage } 2\end{array}$ & 0 & 0 & 0 & 0 & 5 & 20 & 100 \\
\hline \multirow{6}{*}{$\begin{array}{l}\text { Paint use in external } \\
\text { walls of buildings } \\
\text { Paint use in vehicle } \\
\text { manufacturing }\end{array}$} & No control (solvent-based paint) & 81.5 & 78 & 72.5 & 68.5 & 70 & 50 & 0 \\
\hline & Substitution with water-based paint & 18.5 & 22 & 27.5 & 32.5 & 30 & 50 & 100 \\
\hline & $\begin{array}{l}\text { No control (water-based primer, } \\
\text { solvent-based paint for other parts) }\end{array}$ & 100 & 97 & 91 & 84 & 35 & 0 & 0 \\
\hline & Substitution with water-based paint & 0 & 2 & 4 & 6 & 15 & 30 & 0 \\
\hline & Adsorption, incineration & 0 & 1 & 5 & 10 & 40 & 65 & 0 \\
\hline & Substitution + adsorption, incineration & 0 & 0 & 0 & 0 & 0 & 5 & 100 \\
\hline \multirow{2}{*}{$\begin{array}{l}\text { Paint use in vehicle } \\
\text { refinishing }\end{array}$} & No control (solvent-based paint) & 95 & 92.5 & 87.5 & 82.5 & 80 & 40 & 0 \\
\hline & $\begin{array}{l}\text { Substitution with high solids or water-based } \\
\text { paint }\end{array}$ & 5 & 7.5 & 12.5 & 17.5 & 20 & 60 & 100 \\
\hline \multirow{4}{*}{$\begin{array}{l}\text { Paint use in wood } \\
\text { coating }\end{array}$} & No control (solvent-based paint) & 93.5 & 89 & 79 & 69 & 50 & 15 & 0 \\
\hline & Incineration & 0 & 0 & 2 & 4 & 15 & 25 & 20 \\
\hline & Substitution with high solids paint & 2 & 4 & 8 & 12 & 15 & 25 & 20 \\
\hline & Substitution with water-based or UV paint & 4.5 & 7 & 11 & 15 & 20 & 35 & 60 \\
\hline \multirow[t]{3}{*}{ Offset printing } & No control (solvent-based ink) & 94 & 90 & 85 & 80 & 60 & 15 & 0 \\
\hline & Substitution with water-based or UV ink & 6 & 10 & 15 & 20 & 20 & 30 & 10 \\
\hline & Add-on control technology & 0 & 0 & 0 & 0 & 20 & 55 & 90 \\
\hline \multirow{5}{*}{$\begin{array}{l}\text { Flexography and } \\
\text { rotogravure printing } \\
\text { (for packaging) }\end{array}$} & No control (solvent-based ink) & 70 & 64 & 55 & 45 & 30 & 0 & 0 \\
\hline & Substitution with low & 30 & 35 & 40 & 45 & 40 & 30 & 0 \\
\hline & solvent or water-based ink & 0 & 1 & 5 & 10 & 10 & 30 & 0 \\
\hline & Add-on control technology & 0 & 0 & 0 & 0 & 20 & 40 & 100 \\
\hline & Substitution + add-on control technology & & & & & & & \\
\hline \multirow{5}{*}{$\begin{array}{l}\text { Flexography and } \\
\text { rotogravure printing } \\
\text { (for publication) }\end{array}$} & No control (solvent-based ink) & 90 & 85 & 80 & 75 & 62.5 & 5 & 0 \\
\hline & Substitution with low solvent or & 10 & 15 & 20 & 25 & 22.5 & 40 & 0 \\
\hline & water-based ink & 0 & 0 & 0 & 0 & 15 & 50 & 0 \\
\hline & Add-on control technology & & & & & & & \\
\hline & Substitution + add-on control technology & 0 & 0 & 0 & 0 & 0 & 5 & 100 \\
\hline \multirow[t]{4}{*}{ Screen printing } & No control (solvent-based ink) & 90 & 85 & 80 & 75 & 62.5 & 5 & 0 \\
\hline & $\begin{array}{l}\text { Substitution with low solvent or water-based } \\
\text { ink }\end{array}$ & 10 & 15 & 20 & 25 & 22.5 & 40 & 0 \\
\hline & Add-on control technology & 0 & 0 & 0 & 0 & 15 & 50 & 0 \\
\hline & Substitution + add-on control technology & 0 & 0 & 0 & 0 & 0 & 5 & 100 \\
\hline \multirow{2}{*}{$\begin{array}{l}\text { Adhesive use in wood } \\
\text { processing }\end{array}$} & No control & 100 & 97.5 & 92.5 & 87.5 & 90 & 60 & 0 \\
\hline & Add-on control technology & 0 & 2.5 & 7.5 & 12.5 & 10 & 40 & 100 \\
\hline \multirow{3}{*}{$\begin{array}{l}\text { Adhesive use in } \\
\text { manufacturing of shoes }\end{array}$} & No control (solvent-based adhesive) & 90 & 87 & 82.5 & 80 & 70 & 50 & 10 \\
\hline & Substitution with low solvent adhesive & 10 & 13 & 17.5 & 20 & 30 & 50 & 90 \\
\hline & Add-on control technology & 0 & 0 & 0 & 0 & 0 & 0 & 0 \\
\hline
\end{tabular}

increase very slightly by $2 \%$ from 2010 to 2030 , because of slow economic growth rate and a trend towards higher energy efficiency resulting from current legislation. Under implementation of low-carbon policies intended to limit $\mathrm{CO}_{2}$ concentrations to $450 \mathrm{ppm}$, Japan's energy consumption would be reduced by $6 \%$ by 2030 over the 2010 level. This reduction is mainly attributed to the decline in energy consumption of the transportation sector, resulting from improved fuel economy and reduced mileage traveled. By 2030, South Korea's energy consumption is expected to increase by 26 and $15 \%$ over the 2010 level under the two energy scenarios, respectively. Similar to China, there are also evident trends towards clean and renewable energy in Japan and South Ko- rea. For example, from 2010 to 2030, the shares of coal and petroleum products in Japan's energy consumption are expected to decrease from 22 and $40 \%$ to 20 and $31 \%$ under the BAU scenario, respectively, and to 12 and $29 \%$ under the PC scenario. In contrast, the proportion of renewable energy would increase from $16 \%$ in 2010 to $23 \%$ and $33 \%$ in 2030 under the BAU and PC scenarios, respectively.

\subsection{Development of emission control scenarios}

For the countries other than China, our control strategies [0] and [2] are consistent with the control strategies of the reference scenario and the maximum feasible reduction scenario 
Table 7. Summary of national energy consumption in East Asia (Unit: EJ/year ${ }^{-1}$ ).

\begin{tabular}{|c|c|c|c|c|c|c|}
\hline & \multirow{2}{*}{2005} & \multirow{2}{*}{2010} & \multicolumn{2}{|c|}{ BAU } & \multicolumn{2}{|c|}{$\mathrm{PC}$} \\
\hline & & & 2020 & 2030 & 2020 & 2030 \\
\hline China, mainland & 85.31 & 121.75 & 169.41 & 199.55 & 144.39 & 155.01 \\
\hline Power plants & 18.87 & 25.52 & 37.45 & 43.93 & 32.23 & 36.07 \\
\hline Other conversion & 3.11 & 5.30 & 5.98 & 6.49 & 5.07 & 4.84 \\
\hline Industry & 37.79 & 58.16 & 73.64 & 81.68 & 62.83 & 66.51 \\
\hline Residential & 18.12 & 20.79 & 28.05 & 32.78 & 22.96 & 24.01 \\
\hline Transportation & 6.73 & 11.00 & 22.91 & 33.02 & 20.04 & 22.11 \\
\hline Loss & 0.69 & 0.98 & 1.37 & 1.64 & 1.26 & 1.46 \\
\hline Coal & 58.01 & 82.93 & 106.83 & 118.80 & 83.84 & 80.31 \\
\hline Oil & 12.48 & 18.28 & 33.36 & 45.31 & 28.62 & 29.68 \\
\hline Gas & 1.80 & 4.19 & 7.87 & 10.99 & 8.40 & 14.35 \\
\hline Biomass & 7.60 & 7.21 & 7.35 & 6.74 & 6.30 & 6.21 \\
\hline Other renewables and nuclear & 5.43 & 9.15 & 14.01 & 17.71 & 17.24 & 24.45 \\
\hline Japan & 22.03 & 21.36 & 21.78 & 21.86 & 20.93 & 20.09 \\
\hline Power plants & 5.59 & 5.22 & 5.63 & 6.07 & 5.54 & 5.35 \\
\hline Other conversion & 1.62 & 2.25 & 2.27 & 2.21 & 2.13 & 1.93 \\
\hline Industry & 5.61 & 5.32 & 5.62 & 5.57 & 5.45 & 5.30 \\
\hline Residential & 5.03 & 4.86 & 5.17 & 5.48 & 5.02 & 5.28 \\
\hline Transportation & 4.17 & 3.71 & 3.10 & 2.53 & 2.80 & 2.23 \\
\hline Coal & 4.23 & 4.79 & 4.73 & 4.47 & 4.46 & 2.45 \\
\hline Oil & 9.97 & 8.47 & 7.45 & 6.70 & 6.78 & 5.84 \\
\hline Gas & 3.79 & 4.33 & 4.92 & 5.12 & 4.43 & 4.46 \\
\hline Biomass & 0.29 & 0.30 & 0.42 & 0.54 & 0.50 & 0.68 \\
\hline Other renewables and nuclear & 3.76 & 3.50 & 4.30 & 5.07 & 4.82 & 6.68 \\
\hline South Korea & 8.90 & 10.59 & 12.33 & 13.31 & 11.81 & 12.22 \\
\hline Power plants & 2.33 & 2.85 & 3.52 & 4.00 & 3.40 & 3.65 \\
\hline Other conversion & 0.48 & 0.98 & 1.03 & 1.03 & 0.95 & 0.89 \\
\hline Industry & 3.01 & 3.58 & 3.99 & 4.17 & 3.87 & 3.95 \\
\hline Residential & 1.71 & 1.83 & 2.19 & 2.40 & 2.11 & 2.25 \\
\hline Transportation & 1.37 & 1.34 & 1.61 & 1.70 & 1.48 & 1.49 \\
\hline Coal & 2.05 & 3.17 & 3.22 & 3.31 & 3.00 & 1.75 \\
\hline Oil & 3.90 & 4.10 & 4.43 & 4.45 & 4.26 & 4.16 \\
\hline Gas & 1.23 & 1.59 & 2.16 & 2.29 & 1.93 & 2.13 \\
\hline Biomass & 0.09 & 0.13 & 0.19 & 0.28 & 0.22 & 0.37 \\
\hline Other renewables and nuclear & 1.62 & 1.64 & 2.37 & 3.02 & 2.49 & 3.91 \\
\hline North Korea & 1.42 & 1.55 & 1.95 & 2.51 & 1.90 & 1.96 \\
\hline Mongolia & 0.12 & 0.09 & 0.08 & 0.08 & 0.06 & 0.04 \\
\hline Hong Kong \& Macao & 0.76 & 0.93 & 1.30 & 1.39 & 1.16 & 1.08 \\
\hline Taiwan & 4.43 & 4.24 & 4.27 & 4.43 & 3.94 & 4.16 \\
\hline Total & 122.97 & 160.51 & 211.12 & 243.13 & 184.20 & 194.57 \\
\hline Total (except mainland China) & 37.66 & 38.75 & 41.70 & 43.59 & 39.80 & 39.56 \\
\hline
\end{tabular}

in UNEP and WMO (2011), respectively. While control strategy [1] assumes that new pollution control policies would be implemented progressively in China, it has the same assumptions as control strategy [0] for the other countries for the following reasons: (1) China accounts for 88, 94, 94, 95, and $88 \%$ of the total $\mathrm{NO}_{\mathrm{x}}, \mathrm{SO}_{2}, \mathrm{PM}_{10}, \mathrm{PM}_{2.5}$, and NMVOC emissions in East Asia in 2010; (2) Japan and South Korea al- ready have stringent environmental policies in the base year, and the progressive control strategy for countries other than China will have negligible effect on the regional outcomes. The major assumptions underlying control strategies [0] and [2] are straightforward: [0] assumes current regulations and implementation status, while [2] assumes full application of best available technologies in the world. Therefore, in the 
following text, we will focus on the assumptions for China and omit details for other countries. The penetrations of major control technologies in China, Japan, and South Korea are summarized in Table 2 through Table 5.

\subsubsection{Power plants}

As documented in Sect. 2.2.1, the recently released 12th Five-Year Plan set specific targets and proposed detailed technological roadmaps for the reduction of $\mathrm{SO}_{2}$ and $\mathrm{NO}_{\mathrm{x}}$ emissions from power plants. The government did not set a total PM emission target, but rather a strict in-stack PM concentration standard in $2011\left(30 \mathrm{mg} \mathrm{m}^{-3}\right.$ for the entire country except for $20 \mathrm{mg} \mathrm{m}^{-3}$ in key regions, as defined in Sect. 2.2.2). Power plants burning coal with low ash content could attain the $30 \mathrm{mg} \mathrm{m}^{-3}$ threshold by installing ESP and wet-FGD simultaneously. For units burning coal with high ash content, or when the $20 \mathrm{mg} \mathrm{m}^{-3}$ threshold applies, HEDs (including FF and electrostatic-fabric integrated precipitators) would be the only commercially available control technology.

The BAU[0]/PC[0] scenarios consider only the control policies released before the end of 2010. In other words, $\mathrm{NO}_{\mathrm{x}}$ and PM emissions are mainly controlled with LNB and ESP, respectively. The penetration of FGD would increase quite slowly. The BAU[1]/PC[1] scenarios are based on the 12th Five-Year Plan (including the 2011 emission standards for 2011-2015) and the assumption that high-efficiency control technologies will continue to spread gradually after 2015. The penetration of FGD in coal-fired units is assumed to approach $100 \%$ by 2015 . All newly built thermal power plants will be equipped with low- $\mathrm{NO}_{\mathrm{x}}$ combustion technologies and flue gas denitrification (SCR or SNCR) from 2011 onwards. Existing thermal power plants will be upgraded with low$\mathrm{NO}_{\mathrm{x}}$ combustion technologies, and large units ( $\left.\geq 300 \mathrm{MW}\right)$ will be upgraded with SCR or SNCR during 2011-2015. Selective catalytic reduction and SNCR will gradually spread to smaller units after 2015. More ambitious measures will be required in the key regions. For PM, HED will spread much more rapidly, with its share in coal-fired units approaching 35 and $50 \%$ in 2020 and 2030, respectively. In the BAU[2]/PC[2] scenarios, the best available technologies (i.e., FGD for $\mathrm{SO}_{2}, \mathrm{LNB}+\mathrm{SCR}$ for $\mathrm{NO}_{\mathrm{x}}$, and $\mathrm{HED}$ for PM) are assumed to be fully applied by 2030 . Table 2 gives the national average penetration of control technologies. Note that the penetrations in the key regions are usually larger than those of other regions.

\subsubsection{Industrial sector}

The latest national emission standards for industrial boilers were released in 2001 (GB13271-2001), although several provinces including Beijing and Guangdong have recently issued local standards. As the BAU[0]/PC[0] scenarios are based only on current regulations, i.e., nearly no measures implemented for controlling $\mathrm{SO}_{2}$ and $\mathrm{NO}_{\mathrm{x}}$ emissions, and WET remains dominant control technology for PM emissions. The BAU[1]/PC[1] scenarios are based on the 12th Five-Year Plan during 2011-2015; progressive control measures would be enforced after 2015 as an extension of the 12th Five-Year Plan. For $\mathrm{SO}_{2}$, FGD systems are assumed to be widely deployed, penetrating 20,40 , and $80 \%$ of the total capacity by 2015,2020 , and 2030, respectively. For $\mathrm{NO}_{\mathrm{x}}$, LNB will be required at newly built industrial boilers, and existing boilers in the key regions will begin to be retrofitted with LNB during 2011-2015. The vast majority of existing boilers are expected to be equipped with LNB by 2020. For PM, ESP and HED will be gradually deployed to replace the less efficient WET. In the BAU[2]/PC[2] scenarios, the most efficient removal technologies, including FGD, LNB+SCR, and HED, will be fully applied.

The emissions from industry processes (i.e., other than boilers) were mainly regulated by the Emission Standard for Industrial Kilns and Furnaces before 2010. Standards for specific industries were only issued for cement plants (GB49152004) and coke ovens (GB16171-1996). However, new emission standards for a variety of industries were rapidly issued during 2010-2012, which may significantly alter their future emission pathways.

A series of new emission standards for the iron and steel industry was released in 2012, including the standards for sintering, iron production, steel production, steel rolling, and other processes. Sintering is the main source of $\mathrm{SO}_{2}$ and $\mathrm{NO}_{\mathrm{x}}$ emissions in the iron and steel industry, and also an important source of PM emissions. Installation of wet-FGD is required in order to attain the $\mathrm{SO}_{2}$ concentration standard, and the 12th Five-Year Plan also requires large-scale deployment of FGD. The threshold for $\mathrm{NO}_{\mathrm{x}}$ concentration can be attained without additional control technologies, but the 12th Five-Year Plan requires newly built sintering facilities to be equipped with SCR or SNCR. Most sintering plants can meet the PM threshold with simultaneous installation of FGD and ESP, but HED is required for those in key regions and those with poor raw material quality. The BAU[0]/PC[0] scenarios assume only the continuation of the control regulations as of 2010. The BAU[1]/PC[1] scenarios are developed on the basis of the 2012 standard and the 12th Five-Year Plan. Flue gas desulfurization would be installed at most sintering facilities, and SCR or SNCR at newly built ones during 2011-2015; the penetrations would increase gradually afterwards. While ESP remains the dominant PM-removal technology, it is assumed that HED will be deployed gradually. Flue gas desulfurization, SCR, and HED would be fully applied in the BAU[2]/PC[2] scenarios. Blast furnaces (for pig iron production) in China are usually equipped with washing towers and double venturi scrubbers, which currently remain the best available technologies. The 2012 emission standards for steel production (with basic oxygen furnaces and electric arc furnaces being the major technologies) imply that low efficiency WET should be phased out, and HED needs to be 
installed for newly built facilities. While the BAU[0]/PC[0] scenarios assume emission standards from before 2010, the $\mathrm{BAU}[1] / \mathrm{PC}[1]$ scenarios assume the retirement of WET and gradual promotion of HED, according to the 2012 emission standard. The BAU[2]/PC[2] scenarios assume full utilization of HED.

Current emission standards for the cement industry were released in 2004. The $\mathrm{SO}_{2}$ and $\mathrm{NO}_{\mathrm{x}}$ standards can be met without additional control measures, and the PM standard can be met with both ESP and HED. Therefore, we assume the control technology mix of 2010 would remain the same as in the BAU[0]/PC[0] scenarios. In 2012, MEP published new draft of emission standards for public comment. As a cement clinker can absorb most $\mathrm{SO}_{2}$ produced due to its basic chemistry, even the strengthened $\mathrm{SO}_{2}$ limit may be attained under favorable technical conditions. The attainment of the $\mathrm{NO}_{\mathrm{x}}$ limit requires upgrading with low$\mathrm{NO}_{\mathrm{x}}$ combustion technology for existing kilns (or installation of SNCR as an alternative), and simultaneous utilization of low- $\mathrm{NO}_{\mathrm{x}}$ combustion technology and SCR/SNCR for new kilns. The BAU[1]/PC[1] scenarios are based on the 2012 draft standard and the 12th Five-Year Plan. Newly built precalciner kilns (mostly $\geq 4000 \mathrm{td}^{-1}$ ) are required to be equipped with SCR/SNCR, and existing precalciner kilns should be retrofitted with low- $\mathrm{NO}_{\mathrm{x}}$ combustion technology during 2011-2015. Selective catalytic reduction/SNCR are assumed to continue to spread gradually after 2015. HED would be deployed gradually to meet the strengthened PM threshold for new kilns. The BAU[2]/PC[2] scenarios assume full application of desulfurization facilities, $\mathrm{LNB}+\mathrm{SCR}$, and HED.

As for coke ovens, we assume no control measures for $\mathrm{SO}_{2}$ and $\mathrm{NO}_{\mathrm{x}}$ emissions, and continuous application of WET for $\mathrm{PM}$ emissions in the BAU[0]/PC[0] scenarios. In the BAU[1]/PC[1] scenarios, we assume the installation of FGD in the coal-charging process or coke oven gas exhaust for newly built plants (contributing about 50 and $30 \%$ of emissions, respectively) to meet the requirement of a new standard issued in 2012 (GB16171-2012). In addition, new plants are assumed to be equipped with HED, also required by the new standard. The BAU[2]/PC[2] scenarios assume full application of the best desulfurization, denitrification, and PM removal facilities available.

As for glass production, the $\mathrm{BAU}[0] / \mathrm{PC}[0]$ scenarios assume no control measures for $\mathrm{SO}_{2}$ and $\mathrm{NO}_{\mathrm{x}}$ emissions, and the current mix of PM removal technologies. The BAU[1]/PC[1] scenarios are designed according to the new emission standards released in 2011, though they are enforced leniently because of difficulty in implementation. Flue gas desulfurization, as well as end-of-pipe $\mathrm{NO}_{\mathrm{x}}$ control technologies (typically oxy-fuel combustion technology (OXFL) or SCR), would be applied gradually at both existing and new plants. Outdated PM removal technologies, e.g., WET, would be phased out. For the brick industry, emissions from about $30 \%$ of plants remain uncontrolled in 2010. In 2009 a draft of new emission standards call for a PM removal efficiency of over $60 \%$ at existing plants, and over $80 \%$ at new plants. In the BAU[1]/PC[1] scenarios, PM emissions from brick plants are assumed to be controlled according to the standard, though enforced leniently due to inspection difficulty.

To attain the new emission standards for the nitric acid industry (GB26131-2010), the dual-pressure process would be equipped with absorption technologies (ABSP) or SCR, while other processes need to adopt both ABSP and SCR. The BAU[0]/PC[0], BAU[1]/PC[1] and BAU[2]/PC[2] scenarios assume the technology mix of 2010, lenient enforcement of the new standard, and stringent enforcement of the new standard, respectively.

In the $\mathrm{BAU}[0] / \mathrm{PC}[0]$ scenarios, we assume the emission standards for gasoline distribution (GB20950, GB20951, and GB20952) would continue to be enforced in the future. In the BAU[1]/PC[1] scenarios, the enforcement of Stage IA, Stage IB, and Stage II controls would be extended to all of China, and IFC would be applied for both newly built and existing storage tanks. In addition, similar control technologies would be applied for crude oil distribution. As a result, the application rate of IFC, Stage IA, and Stage IB+Stage II control measures in gasoline storage and distribution would approach 75 and $100 \%$ by 2020 and 2030, respectively. The application rate in crude oil distribution would be 25 and $50 \%$ by 2020 and 2030, respectively (see Table 4 ). For the $\mathrm{BAU}[2] / \mathrm{PC}[2]$ scenarios, these control measures would be fully applied by 2030 .

For other industries with NMVOC emissions, nearly no control measures are assumed for the BAU[0]/PC[0] scenarios. In the BAU[1]/PC[1] scenarios, we assume that new NMVOC emission standards (similar to or slightly less stringent than the EU Directives 1999/13/EC and 2004/42/EC, depending on specific industry) will be released and implemented in key regions as of 2015, and in other provinces as of 2020. Afterwards, the emission standards will become more stringent gradually (see Table 4). In terms of technologies, we assume application of basic management techniques (e.g., leakage detection and repair for refineries and improved solvent management in paint production) where they are applicable. End-of-pipe controls (condensation, adsorption, absorption, and incineration) are adopted when high removal rate is required. The penetration of selected control measures assumed for key sources are summarized in Table 4.

\subsubsection{Residential sector}

Emission control policies have seldom been proposed for the residential sector in China. In the BAU[0]/PC[0] scenarios, we assume no control measures except for the continued application of CYC and WET for residential boilers. In BAU[1]/PC[1], HED and low-sulfur-derived coal are assumed to be deployed gradually, both penetrating 20 and $40 \%$ of the total capacity by 2020 and 2030 , respectively. 
In addition, we assume gradual adoption of advanced coal stoves and advanced biomass stoves (e.g., those with more efficient combustion or catalytic devices) where applicable, which reduce emissions of PM and NMVOC. The BAU[2]/PC[2] scenarios assume the application of best available technology without considering economic cost.

\subsubsection{Transportation sector}

In the BAU[0]/PC[0] scenarios, only the existing standards (released before the end of 2010) are considered. In the BAU[1]/PC[1] scenarios, all of the current standards in Europe are assumed to be implemented in China gradually, and the time intervals between the releases of standard stages would be a little shorter than those of Europe. The implementation timeline of the emission standards is given in Fig. 1. The removal efficiencies of the future emission standards are from the GAINS-Asia model of IIASA (Amann et al., 2008, 2011). The BAU[2]/PC[2] scenarios assume the same implementation timeline for new standards as the BAU[1]/PC[1] scenario. In addition, old vehicles with high emissions are phased out at a faster pace through compulsory measures and economic subsidies. The proportions of vehicles subject to different emission standards are summarized in Table 5.

\subsubsection{Solvent use and open biomass burning}

For emissions from solvent use, the BAU[0]/PC[0] scenarios consider only several national standards limiting the NMVOC content of some solvent products (see Sect. 2.2.5). Major assumptions for the BAU[1]/PC[1] scenarios are consistent with the NMVOC emission sources in the industrial sector, i.e., implementation of the EU Directives 1999/13/EC and 2004/42/EC as of 2015-2020, followed by gradually strengthened regulations afterwards. Potential mitigation measures to attain the European standards differ greatly for different emissions sources because of various spraying technologies and chemical properties of the solvent used. However, similar to the industrial sources, these measures can be categorized into two kinds: use of environmentally friendly substitutes (e.g., water-based or UV products) or end-of-pipe control technologies. Substitution measures are assumed where applicable, while end-of-pipe control technologies would be mainly installed in newly built factories. The penetration of selected control measures assumed for key sources are summarized in Table 6.

Under current regulations and implementation status, the $\mathrm{NO}_{\mathrm{x}}$ emissions in East Asia other than China are expected to decrease by $27 \%$, with especially rapid decline in Japan $(47 \%)$ and South Korea (34\%). The decrease is mainly attributable to the continuously increasing proportion of vehicles subject to stringent emission standards. With the enforcement of energy-saving policies intended to limit global temperature increase to $2^{\circ} \mathrm{C}$ (reflected by the difference between the $\mathrm{BAU}[0]$ and the $\mathrm{PC}[0]$ scenarios), $\mathrm{NO}_{\mathrm{x}}$ emissions in East Asia outside of China, and of the two major energy consumers therein (Japan and South Korea), are all expected to decline by $15-17 \%$ in 2030 compared with the baseline projection. These policies are most effective in the power sector, due to negligible emissions from renewable and nuclear power generation compared with traditional coal-fired power. The full application of technically feasible control measures (the $\mathrm{PC}[2]$ scenario) would reduce the $\mathrm{NO}_{\mathrm{x}}$ emissions in East Asia except China, and Japan and South Korea individually to only 30,46 and $30 \%$ of the baseline projection, or 22,24 and $20 \%$ of the 2010 levels, respectively.

\subsection{6 $\quad \mathrm{SO}_{2}$}

The $\mathrm{SO}_{2}$ emissions in East Asia are predicted to grow $24 \%$ from 2010 to 2030 under current regulations and implementation status (the BAU[0] scenario). The enforcement of advanced energy-saving measures (the $\mathrm{PC}[0]$ scenario) could lead to a substantial $36 \%$ reduction in $\mathrm{SO}_{2}$ emissions from the baseline projection, exceeding the effect of progressively implemented end-of-pipe control measures, $25 \%$ (reflected by the difference between the PC[0] and the PC[1] scenarios). Flue gas desulfurization facilities had been intensively deployed by 2010 in most industrial sources of Japan and in the power plants of China and South Korea. Therefore, the reduction potential through the installation of end-of-pipe control technologies will likely decline in the future, spotlighting the importance of energy-saving measures for further reduction of $\mathrm{SO}_{2}$ emissions. With the full application of best available technologies (the $\mathrm{PC}[2]$ scenario), the remaining $\mathrm{SO}_{2}$ emissions in East Asia would account for only $27 \%$ of the baseline projection, or $34 \%$ of the 2010 levels.

Similar to $\mathrm{NO}_{\mathrm{x}}$, China's $\mathrm{SO}_{2}$ emissions have a larger growth potential than the average of East Asia during 20102030 under the current policy and implementation status. Implementation of new energy-saving measures (reflected by the difference between the BAU[0] and the PC[0] scenarios) and progressive end-of-pipe control measures (reflected by the difference between the $\mathrm{PC}[0]$ and the $\mathrm{PC}[1]$ scenarios) could lead to 36 and $26 \%$ reductions of China's $\mathrm{SO}_{2}$ emissions, respectively (compared with the baseline projection). Consistent with the total emissions in East Asia, the contribution of energy-saving measures clearly exceeds the planned end-of-pipe control policies. As the power sector had largely been equipped with FGD facilities by the base year, industrial boilers and industrial process contribute $82 \%$ of the $\mathrm{SO}_{2}$ emission reduction achieved through progressive end-of-pipe control policies. Assuming the full enforcement of technically feasible control measures ( $\mathrm{PC}[2]$ ), $\mathrm{SO}_{2}$ emissions are estimated to reach only $27 \%$ of the baseline projection, or $34 \%$ of the 2010 levels.

We also note that China's $\mathrm{SO}_{2}$ emissions are projected to be $21.7 \mathrm{Mt}$ in 2015 under the BAU[1] scenario, $11.1 \%$ lower than those of 2010. This implies that if the control policies in the 12th Five-Year Plan could be implemented successfully 
Table 8. Summary of national air pollutant emissions in East Asia (Unit: Mt/year ${ }^{-1}$ ).

\begin{tabular}{|c|c|c|c|c|c|c|c|c|c|c|c|c|}
\hline & \multicolumn{2}{|c|}{ Base year } & \multicolumn{2}{|c|}{ BAU[0] } & \multicolumn{2}{|c|}{ BAU[1] } & \multirow{2}{*}{$\begin{array}{r}\text { BAU[2] } \\
2030\end{array}$} & \multicolumn{2}{|c|}{$\mathrm{PC}[0]$} & \multicolumn{2}{|c|}{$\mathrm{PC}[1]$} & \multirow{2}{*}{$\begin{array}{r}\mathrm{PC}[2] \\
2030\end{array}$} \\
\hline & 2005 & 2010 & 2020 & 2030 & 2020 & 2030 & & 2020 & 2030 & 2020 & 2030 & \\
\hline $\mathrm{NO}_{\mathrm{x}}$ & & & & & & & & & & & & \\
\hline China, mainland & 19.48 & 26.05 & 31.69 & 35.35 & 19.18 & 15.82 & 9.85 & 26.32 & 25.16 & 15.95 & 11.47 & 7.18 \\
\hline Japan & 2.050 & 1.616 & 1.033 & 0.860 & 1.033 & 0.860 & 0.461 & 0.954 & 0.727 & 0.954 & 0.727 & 0.392 \\
\hline South Korea & 1.112 & 1.055 & 0.809 & 0.697 & 0.809 & 0.697 & 0.245 & 0.778 & 0.575 & 0.778 & 0.575 & 0.210 \\
\hline North Korea & 0.276 & 0.284 & 0.345 & 0.481 & 0.345 & 0.481 & 0.086 & 0.342 & 0.375 & 0.342 & 0.375 & 0.067 \\
\hline Mongolia & 0.064 & 0.058 & 0.055 & 0.057 & 0.055 & 0.057 & 0.041 & 0.052 & 0.047 & 0.052 & 0.047 & 0.034 \\
\hline Hong Kong \& Macao & 0.199 & 0.230 & 0.229 & 0.260 & 0.229 & 0.260 & 0.039 & 0.208 & 0.218 & 0.208 & 0.218 & 0.033 \\
\hline Taiwan & 0.551 & 0.440 & 0.348 & 0.342 & 0.348 & 0.342 & 0.091 & 0.316 & 0.287 & 0.316 & 0.287 & 0.076 \\
\hline Total & 23.73 & 29.74 & 34.51 & 38.05 & 21.99 & 18.51 & 10.81 & 28.97 & 27.39 & 18.60 & 13.70 & 8.00 \\
\hline $\begin{array}{l}\text { Total except mainland China } \\
\mathrm{SO}_{2}\end{array}$ & 4.252 & 3.682 & 2.819 & 2.697 & 2.819 & 2.697 & 0.963 & 2.649 & 2.229 & 2.649 & 2.229 & 0.813 \\
\hline China, mainland & 28.70 & 24.42 & 29.07 & 30.68 & 20.59 & 18.23 & 13.32 & 22.24 & 19.49 & 15.69 & 11.55 & 8.34 \\
\hline Japan & 0.705 & 0.562 & 0.520 & 0.518 & 0.520 & 0.518 & 0.294 & 0.507 & 0.470 & 0.507 & 0.470 & 0.268 \\
\hline South Korea & 0.410 & 0.400 & 0.408 & 0.358 & 0.408 & 0.358 & 0.162 & 0.384 & 0.301 & 0.384 & 0.301 & 0.141 \\
\hline North Korea & 0.268 & 0.297 & 0.368 & 0.471 & 0.368 & 0.471 & 0.099 & 0.363 & 0.333 & 0.363 & 0.333 & 0.070 \\
\hline Mongolia & 0.087 & 0.073 & 0.065 & 0.073 & 0.065 & 0.073 & 0.011 & 0.054 & 0.036 & 0.054 & 0.036 & 0.005 \\
\hline Hong Kong \& Macao & 0.022 & 0.016 & 0.019 & 0.021 & 0.019 & 0.021 & 0.007 & 0.017 & 0.016 & 0.017 & 0.016 & 0.006 \\
\hline Taiwan & 0.244 & 0.139 & 0.115 & 0.119 & 0.115 & 0.119 & 0.026 & 0.104 & 0.122 & 0.104 & 0.122 & 0.026 \\
\hline Total & 30.44 & 25.91 & 30.57 & 32.24 & 22.08 & 19.78 & 13.92 & 23.67 & 20.77 & 17.12 & 12.83 & 8.85 \\
\hline $\begin{array}{l}\text { Total except mainland China } \\
\mathrm{PM}_{10}\end{array}$ & 1.735 & 1.486 & 1.496 & 1.559 & 1.496 & 1.559 & 0.599 & 1.431 & 1.278 & 1.431 & 1.278 & 0.516 \\
\hline China, mainland & 18.61 & 15.81 & 16.24 & 15.26 & 13.24 & 10.53 & 5.55 & 13.13 & 11.15 & 10.76 & 7.52 & 4.17 \\
\hline Japan & 0.206 & 0.167 & 0.137 & 0.125 & 0.137 & 0.125 & 0.087 & 0.131 & 0.111 & 0.131 & 0.111 & 0.078 \\
\hline South Korea & 0.093 & 0.116 & 0.115 & 0.117 & 0.115 & 0.117 & 0.062 & 0.112 & 0.111 & 0.112 & 0.111 & 0.059 \\
\hline North Korea & 0.596 & 0.558 & 0.557 & 0.599 & 0.557 & 0.599 & 0.134 & 0.477 & 0.444 & 0.477 & 0.444 & 0.099 \\
\hline Mongolia & 0.053 & 0.040 & 0.034 & 0.035 & 0.034 & 0.035 & 0.008 & 0.029 & 0.019 & 0.029 & 0.019 & 0.004 \\
\hline Hong Kong \& Macao & 0.039 & 0.043 & 0.049 & 0.046 & 0.049 & 0.046 & 0.012 & 0.043 & 0.033 & 0.043 & 0.033 & 0.009 \\
\hline Taiwan & 0.095 & 0.085 & 0.078 & 0.081 & 0.078 & 0.081 & 0.035 & 0.072 & 0.066 & 0.072 & 0.066 & 0.029 \\
\hline Total & 19.69 & 16.81 & 17.21 & 16.26 & 14.21 & 11.53 & 5.88 & 13.99 & 11.94 & 11.62 & 8.31 & 4.45 \\
\hline $\begin{array}{l}\text { Total except mainland China } \\
\mathrm{PM}_{2.5}\end{array}$ & 1.082 & 1.007 & 0.970 & 1.002 & 0.970 & 1.002 & 0.338 & 0.864 & 0.784 & 0.864 & 0.784 & 0.277 \\
\hline China, mainland & 13.34 & 11.79 & 11.74 & 10.87 & 9.61 & 7.29 & 3.41 & 9.43 & 7.73 & 7.71 & 5.03 & 2.50 \\
\hline Japan & 0.142 & 0.102 & 0.084 & 0.077 & 0.084 & 0.077 & 0.051 & 0.077 & 0.064 & 0.077 & 0.064 & 0.044 \\
\hline South Korea & 0.071 & 0.085 & 0.082 & 0.083 & 0.082 & 0.083 & 0.051 & 0.080 & 0.079 & 0.080 & 0.079 & 0.048 \\
\hline North Korea & 0.407 & 0.383 & 0.401 & 0.426 & 0.401 & 0.426 & 0.101 & 0.349 & 0.329 & 0.349 & 0.329 & 0.078 \\
\hline Mongolia & 0.025 & 0.019 & 0.016 & 0.016 & 0.016 & 0.016 & 0.004 & 0.014 & 0.010 & 0.014 & 0.010 & 0.002 \\
\hline Hong Kong \& Macao & 0.023 & 0.024 & 0.026 & 0.027 & 0.026 & 0.027 & 0.006 & 0.023 & 0.022 & 0.023 & 0.022 & 0.005 \\
\hline Taiwan & 0.057 & 0.049 & 0.045 & 0.047 & 0.045 & 0.047 & 0.019 & 0.041 & 0.038 & 0.041 & 0.038 & 0.016 \\
\hline Total & 14.07 & 12.45 & 12.39 & 11.55 & 10.27 & 7.97 & 3.64 & 10.01 & 8.27 & 8.29 & 5.57 & 2.69 \\
\hline $\begin{array}{l}\text { Total except mainland China } \\
\text { NMVOC }\end{array}$ & 0.724 & 0.662 & 0.653 & 0.676 & 0.653 & 0.676 & 0.231 & 0.584 & 0.542 & 0.584 & 0.542 & 0.193 \\
\hline China, mainland & 18.89 & 22.86 & 26.29 & 28.97 & 22.90 & 20.46 & 12.62 & 23.70 & 24.30 & 20.53 & 16.80 & 10.37 \\
\hline Japan & 1.755 & 1.223 & 1.218 & 1.268 & 1.218 & 1.268 & 0.297 & 1.217 & 1.262 & 1.217 & 1.262 & 0.291 \\
\hline South Korea & 0.756 & 0.866 & 0.875 & 0.943 & 0.875 & 0.943 & 0.286 & 0.743 & 0.794 & 0.743 & 0.794 & 0.253 \\
\hline North Korea & 0.401 & 0.389 & 0.463 & 0.577 & 0.463 & 0.577 & 0.081 & 0.423 & 0.481 & 0.423 & 0.481 & 0.068 \\
\hline Mongolia & 0.022 & 0.020 & 0.019 & 0.019 & 0.019 & 0.019 & 0.004 & 0.017 & 0.016 & 0.017 & 0.016 & 0.004 \\
\hline Hong Kong \& Macao & 0.123 & 0.138 & 0.160 & 0.178 & 0.160 & 0.178 & 0.146 & 0.156 & 0.170 & 0.156 & 0.170 & 0.140 \\
\hline Taiwan & 0.599 & 0.402 & 0.243 & 0.203 & 0.243 & 0.203 & 0.166 & 0.223 & 0.180 & 0.223 & 0.180 & 0.147 \\
\hline Total & 22.55 & 25.90 & 29.27 & 32.16 & 25.88 & 23.64 & 13.60 & 26.48 & 27.20 & 23.31 & 19.70 & 11.27 \\
\hline Total except mainland China & 3.657 & 3.039 & 2.977 & 3.188 & 2.977 & 3.188 & 0.980 & 2.780 & 2.902 & 2.780 & 2.902 & 0.901 \\
\hline
\end{tabular}

(as assumed in the BAU[1] scenario), the national target to reduce the $\mathrm{SO}_{2}$ emissions by $8 \%$ during 2011-2015 would be achieved.
The $\mathrm{SO}_{2}$ emissions in East Asia outside of China, including Japan and South Korea individually, are expected to stay relatively stable until 2030 under current regulations. The implementation of new energy-saving polices (the PC[0] 
scenario) could lead to a 9-18\% reduction in $\mathrm{SO}_{2}$ emissions from the levels of the baseline projection. The reduction is mainly achieved thorough the promotion of nuclear and renewable power generation and replacement with cleaner fuels in the industrial sector. Under the full application of technically feasible reduction measures (the PC[2] scenario), the $\mathrm{SO}_{2}$ emissions in East Asia except China, and Japan and South Korea individually would be reduced to 33,52 and $39 \%$ of the baseline projection, respectively.

\subsection{7 $\mathrm{PM}_{10}$ and $\mathrm{PM}_{2.5}$}

$\mathrm{PM}_{10}$ and $\mathrm{PM}_{2.5}$ emissions in East Asia are projected to remain relatively stable up until 2030 under the current policies (the BAU[0] scenario), resulting from growth in energy consumption offset by reduction from existing control policies (in particular, vehicle emission standards). New energy-saving policies (reflected by the difference between the BAU[0] and the $\mathrm{PC}[0]$ scenarios) and progressive end-ofpipe control measures (reflected by the difference between the $\mathrm{PC}[0]$ and the $\mathrm{PC}[1]$ scenarios) result in about 28 and $23 \%$ reduction in $\mathrm{PM}_{10}$ and $\mathrm{PM}_{2.5}$ emissions from the levels of baseline projection, respectively. Full application of best available technologies (the PC[2] scenario) could reduce $\mathrm{PM}_{10}$ and $\mathrm{PM}_{2.5}$ emissions to about one-quarter of the levels of the baseline projection or the base year.

China's future $\mathrm{PM}_{10}$ and $\mathrm{PM}_{2.5}$ emission trends under the studied scenarios are quite similar to those of East Asia as a whole. Similar to $\mathrm{SO}_{2}$, the effects of advanced energysaving polices (resulting in about $29 \%$ reduction of $\mathrm{PM}_{2.5}$ emissions from the baseline projection) exceeds the planned end-of-pipe control measures (about a $25 \%$ reduction). With the energy-saving measures applied, the reduction in emissions from the residential sector is especially pronounced (nearly $60 \%$ ), resulting from the replacement of coal and biomass with cleaner fuel types. The most effective end-ofpipe control policies are the application of recently released new emission standards for various industrial sources. We estimate that these new industrial standards lead to over $20 \%$ reduction of China's total $\mathrm{PM}_{10}$ and $\mathrm{PM}_{2.5}$ emissions. If the best available technologies are fully applied (the PC[2] scenario), the $\mathrm{PM}_{10}$ and $\mathrm{PM}_{2.5}$ emissions would be reduced to about one-quarter of the levels of baseline projection or the levels of the base year.

The total $\mathrm{PM}_{10}$ and $\mathrm{PM}_{2.5}$ emissions in East Asia other than China are also expected to remain relatively stable up until 2030 under the current policies. An exception is Japan, whose $\mathrm{PM}_{10}$ and $\mathrm{PM}_{2.5}$ emissions are projected to decrease about one-quarter by 2030. The major driving force underlying this decline would be an increasing proportion of vehicles regulated by newer emission standards. The implementation of new energy-saving policies (the $\mathrm{PC}[0]$ scenario) is expected to reduce the $\mathrm{PM}_{2.5}$ emissions of East Asia other than China, and Japan and South Korea individually by about 20,17 , and $5 \%$, respectively, from the baseline projection.
With full application of best available control technologies (the PC[2] scenario), the $\mathrm{PM}_{2.5}$ emissions in East Asia except China, and Japan and South Korea individually would account for about one-quarter, one-half, and one-half of the levels of the baseline projection, respectively.

\subsubsection{NMVOC}

Under current regulations and implementation status (the BAU[0] scenario), NMVOC emissions in East Asia are projected to increase by $24 \%$ by 2030 from the 2010 levels. The implementation of assumed energy-saving measures (reflected by the difference between the BAU[0] and the PC[0] scenarios) and progressive end-of-pipe control measures (reflected by the difference between the PC[0] and the PC[1] scenarios) are expected to reduce NMVOC emissions by 15 and $23 \%$, respectively, from the baseline projection. Up to $62 \%$ of the total NMVOC emissions are expected to remain even with the assumed energy-saving measures and progressive end-of-pipe controls enforced together. There remains large potential to reduce NMVOC emissions beyond the progressive control strategies, since the full application of best available technologies (the PC [2] scenario) could reduce NMVOC emissions to only $35 \%$ of the baseline projection.

China's NMVOC emissions are estimated to increase by $27 \%$ from 2010 to 2030 under the current policy and implementation status. This upward trend is stronger than the East Asia average but weaker than China's $\mathrm{NO}_{\mathrm{x}}$ emissions. The emissions from the transportation and residential sectors are expected to decline as a result of existing emission standards for vehicles and the dwindling direct combustion of biomass in the residential sector. By carrying out a series of energy-saving policies (the $\mathrm{PC}[0]$ scenario), total emissions are expected to decrease by $16 \%$ from the baseline projection. Emissions from the residential sector decrease most notably because of the substitution of biomass with cleaner fuels. Another $26 \%$ could be reduced if progressive end-ofpipe control measures are implemented (reflected by the difference between the PC[0] and the PC[1] scenarios), and the most effective measures are the substitution with low-solvent products and end-of-pipe removal technologies such as incineration and adsorption in the industrial sector and the use of solvents. With full implementation of the best available technologies (the PC[2] scenario), the NMVOC emissions could be reduced to about one-third of the levels of the baseline scenario.

The NMVOC emissions in East Asia outside of China are expected to increase by $5 \%$ from 2010 to 2030 under current regulations. The growth rates in Japan and South Korea are 4 and $9 \%$, respectively. This slight upward trend is an integrated effect of the reduction in transportation emissions due to increased share of low emission vehicles, and the increase of emissions from solvent use due to inadequate control policies. By 2030, solvent use contributes about $80 \%$ of total NMVOC emissions in both Japan and Korea under the 


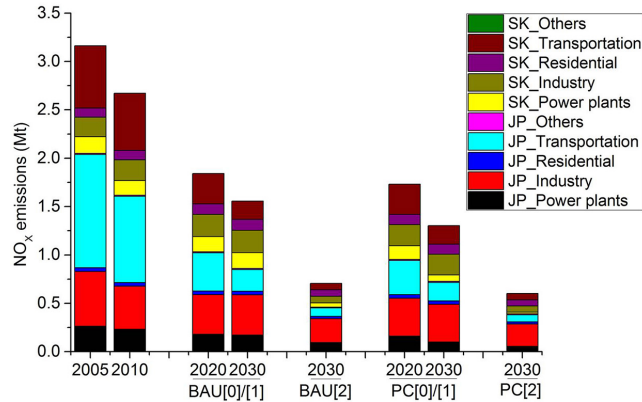

(a)

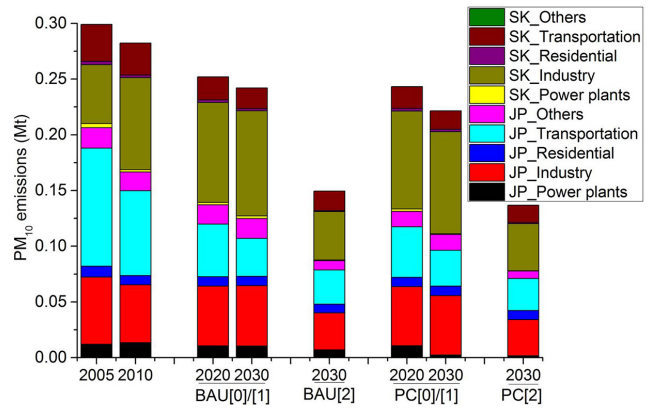

(c)

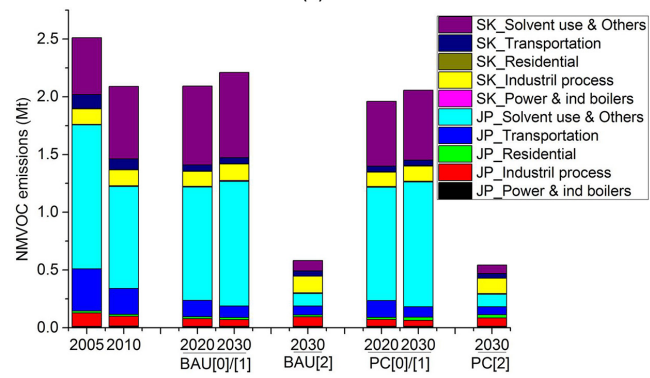

(e)

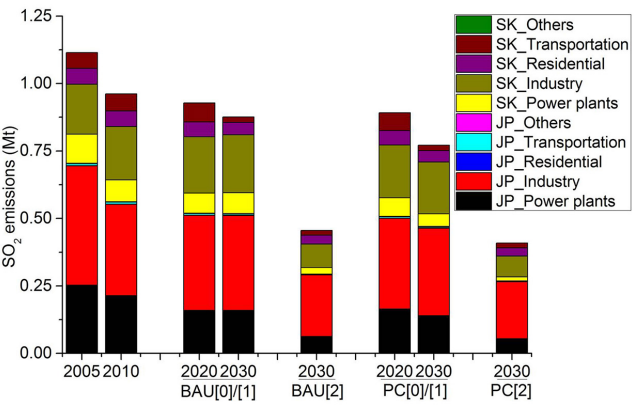

(b)

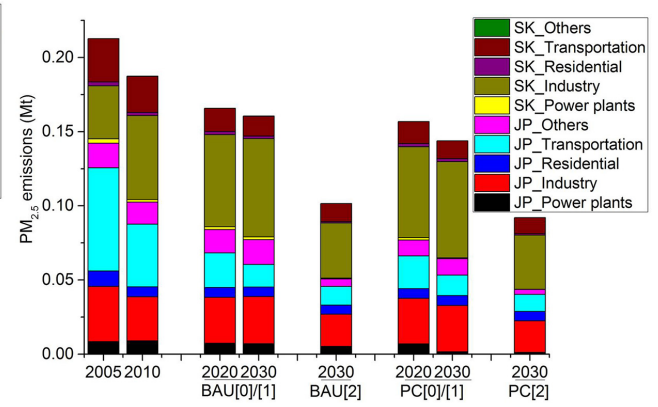

(d)

Figure 3. Emissions of major air pollutants in Japan and South Korea and their sectoral distributions during 2005-2030: (a) $\mathrm{NO}_{\mathrm{x}}$; (b) $\mathrm{SO}_{2}$; (c) $\mathrm{PM}_{10}$; (d) $\mathrm{PM}_{2.5}$; (e) NMVOC. In the legend, JP and SK represent Japan and South Korea, respectively. The sector of "Others" is the same as in Fig. 2.

baseline projection. As solvent use has little to do with fuel consumption, the implementation of energy-saving policies has very limited effects on the reduction of NMVOC emissions. In contrast, the full application of end-of-pipe control measures (the $\mathrm{PC}[2]$ scenario) would reduce the emissions from solvent use dramatically, to about one-quarter of the baseline projection.

\section{Comparison with other studies and observations}

\subsection{Comparison with other studies}

In 2010, China contributed $88,94,94,95$, and $88 \%$ of the total $\mathrm{NO}_{\mathrm{x}}, \mathrm{SO}_{2}, \mathrm{PM}_{10}, \mathrm{PM}_{2.5}$, and $\mathrm{NMVOC}$ emissions in East Asia, respectively. As a developing country, China has substantial potential to reduce air pollutant emissions with the implementation of aggressive control policies, and com- bined with its sheer size it is therefore expected to dominate the emission trends of East Asia in the next 20 years. Many previous studies projecting emissions have focused on China. While some Asian and international studies have incorporated Japan, South Korea, and other countries to produce regional projections, they have seldom disaggregated emissions by country, making it difficult to review their projections. For these reasons, our comparisons with prior literature in this section are limited to comparisons of China's emission trends.

There are numerous studies estimating historical emissions of China. Since this study focuses on temporal trends, we exclude in our comparisons the numerous studies estimating emissions for only a single year.

As for future projections, early studies (reported before 2005) of China's emissions (van Aardenne et al., 1999; Streets and Waldhoff, 2000; Klimont et al., 2001, 2002) were based on the emissions of 1995 or before. They generally 
(a)

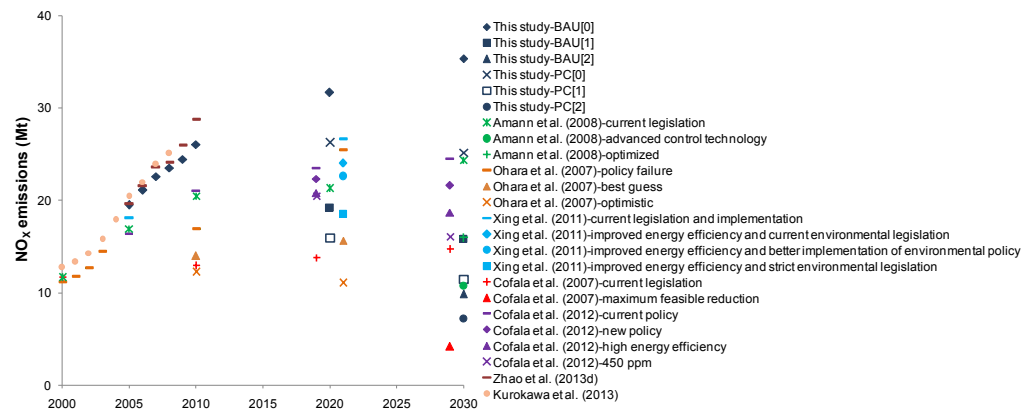

(b)

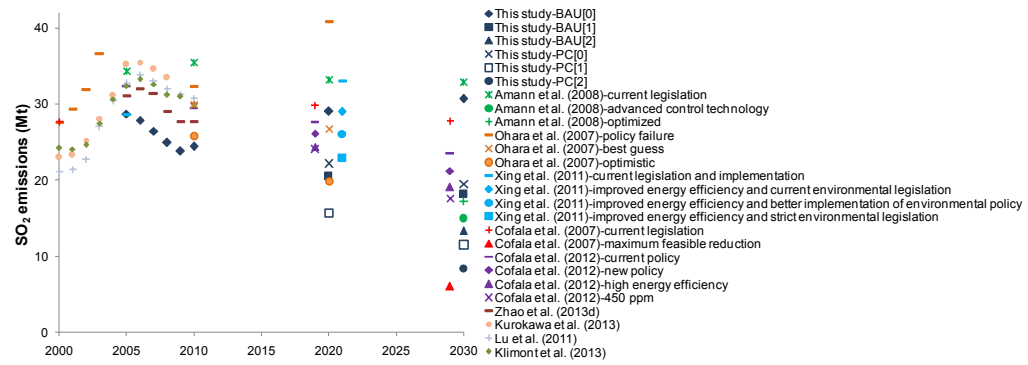

(c)

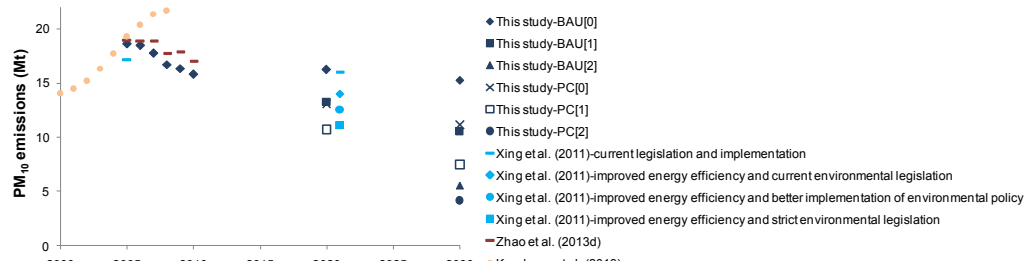

(d)

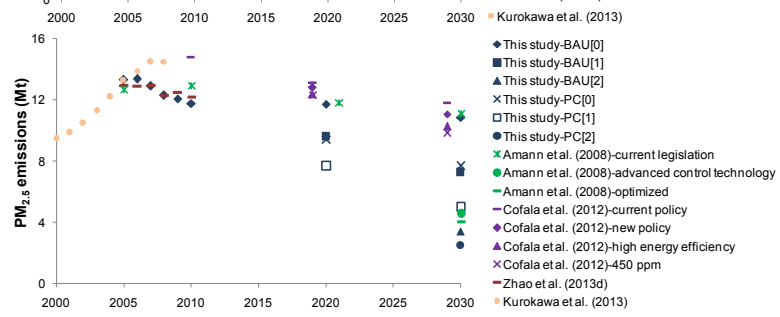

(e)

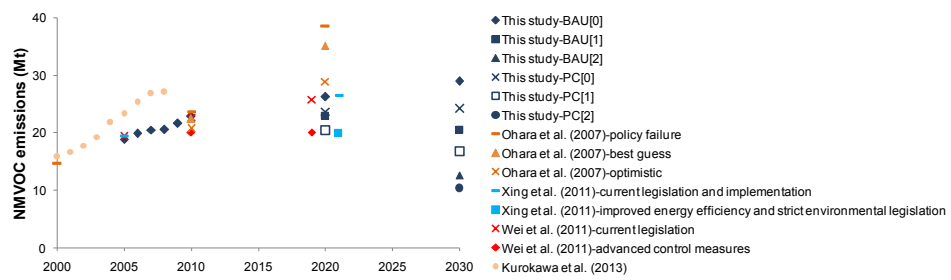

Figure 4. Comparison of estimated emissions in this study with those of other studies: (a) $\mathrm{NO}_{\mathrm{x}}$; (b) $\mathrm{SO}_{2}$; (c) $\mathrm{PM}_{10}$; (d) $\mathrm{PM}_{2.5}$; (e) $\mathrm{NMVOC}_{\text {. }}$ The scenarios from the same study are shown with symbols of the same color, and since their historical emissions duplicate each other, we show just the historical values of one scenario. Some points for the years 2020 and 2030 are shifted slightly to the left or right in order to avoid overlapping representation. Note that the current legislation scenario in Amann et al. (2008) is consistent with the baseline scenario in Klimont et al. (2009), and the historical emission trends of Zhao et al. (2013a) is consistent with this study. Therefore, Klimont et al. (2009) and Zhao et al. (2013a) are not shown in the figures.

substantially underestimated the rapid economic growth during 2000-2010. In addition, none of them anticipated the aggressive control policies put in place in China starting in 2005. Therefore, these projections deviated greatly from the actual trends. In this study, we only compare emission projections reported since 2005 (or using the base year of
2000 or later) with our projections, which are shown in Fig. 4.

\subsection{1 $\mathrm{NO}_{\mathrm{x}}$ emissions}

Y. Zhao et al. (2013) and Kurokawa et al. (2013) evaluated recent $\mathrm{NO}_{\mathrm{x}}$ emission trends in China. They both presented 
similar temporal trends to our estimation. The estimated growth rates of China's $\mathrm{NO}_{\mathrm{x}}$ emissions are all within the range of $20-23 \%$ for the period $2005-2008$, and $34-47 \%$ for the period of 2005-2010.

Ohara et al. (2007) projected $\mathrm{NO}_{\mathrm{x}}$ emissions in China through 2020 by using the emissions for 2000 and three scenarios: a "policy failure" scenario, a "best guess" scenario, and an optimistic scenario. The projections of all the three scenarios for 2010 were much lower than our estimates, indicating they underestimated the economic growth during 2000-2010. The three scenarios projected growth rates ranging between 51 and $-10 \%$ for the period 2010-2020. In contrast, even the progressive control strategy in our study results in a larger decline of $\mathrm{NO}_{\mathrm{x}}$ emissions $(-26 \%$ in the BAU[1] scenario and $-39 \%$ in the PC[1] scenario) during the same period, due to the implementation of the control measures scheduled in the 12th Five-Year Plan. Amann et al. (2008) developed three scenarios through 2030 based on the emissions in 2005. The "current legislation" scenario assumed current regulations and enforcement, while the "advanced control technology" scenario assumed acrossthe-board application of such technologies, largely based on existing German regulations. The optimized scenario was a least-cost optimization that would achieve the same health benefit as the advanced control technology scenario. Xing et al. (2011) projected $\mathrm{NO}_{\mathrm{x}}$ emissions for 2020 with four scenarios based on the emissions of 2005, including one assuming current regulations and implementation status, one assuming improvement of energy efficiency and current environmental regulations, one assuming improvement of energy efficiency and better implementation of environmental regulations, and a final scenario assuming improvement of energy efficiency and strict environmental regulations. These two studies (Amann et al., 2008 and Xing et al., 2011) were conducted cooperatively. Similar to Ohara et al. (2007), their projections for 2010 were also significantly lower than our estimations. As for the growth rates until 2020 and 2030, all the scenarios in these two studies projected a larger increase or smaller decline than our progressive control strategy assuming the enforcement of the 12th Five-Year Plan, indicating these two studies did not anticipate stringent future control policies. Cofala et al. (2012) projected the $\mathrm{NO}_{\mathrm{x}}$ emissions until 2030 based on 2010 emissions and four scenarios envisaging energy-saving measures at different stringency levels. The projected rates of change for 2010-2030 range between 16 and $-24 \%$. Since no end-of-pipe control measures beyond the baseline are considered, it is only meaningful to compare these scenarios with our BAU[0] and PC[0] scenarios, which projected the growth rates for the same period at 36 and $-3 \%$, respectively. This study predicted a stronger growth potential of China's energy consumption in the future, leading to the larger rate of growth or smaller rate of decline above.

\subsection{2 $\mathrm{SO}_{2}$ emissions}

A number of studies have evaluated China's recent $\mathrm{SO}_{2}$ emission trends (Klimont et al., 2013; Lu et al., 2011; Y. Zhao et al., 2013; Kurokawa et al., 2013). Although the emission estimates in different studies differ by up to $30 \%$ during the period, all of the reviewed studies and our own show declining $\mathrm{SO}_{2}$ emissions during 2005-2010. This study estimated a slightly stronger decline (13\% for 2005-2008, and $15 \%$ for 2005-2010) compared with the previous studies (2-8\% for 2005-2008, and 2-12\% for 2005-2010).

Most of the projections reviewed here have more or less envisaged China's recent $\mathrm{SO}_{2}$ control policies. Ohara et al. (2007) predicted that $\mathrm{SO}_{2}$ emissions would change by $27,-11$, and $-23 \%$ during $2010-2020$ in their policy failure, best-guess, and optimistic scenarios, respectively, comparable to our BAU[0], PC[0], and BAU[1] scenarios, respectively. Amann et al. (2008) failed to reproduce the declining trend during 2005-2010, but the control policies assumed in its most aggressive scenario (the advanced control technology scenario) resulted in a similar rate of decline as of 2030 as our progressive control strategy. The growth rates projected in all four scenarios of Xing et al. (2011) are higher than our BAU[1] scenario, indicating that their assumptions of future $\mathrm{SO}_{2}$ control policies are more conservative than our progressive control strategy based on the 12th Five-Year Plan. Cofala et al. (2012) predicted $\mathrm{SO}_{2}$ emissions to decrease by $20-40 \%$ during $2010-2030$ under four different energy-saving policy scenarios, while our BAU[0] and PC[0] scenarios predicted rates of change at 26 and $-20 \%$, respectively. As described in Sect. 4.1.1, the differences are also attributed to a stronger growth potential of China's energy consumption projected in our study.

\subsubsection{PM emissions}

Y. Zhao et al. (2013) and Kurokawa et al. (2013) have evaluated the recent trends of $\mathrm{PM}_{10}$ and $\mathrm{PM}_{2.5}$ emissions in China. While Y. Zhao et al. (2013) and this study both showed a declining trend during 2005-2010, Kurokawa et al. (2013) estimated a significant upward trend after 2005. The discrepancy may be attributed mainly to the uncertainty in the penetration levels of dust collectors at industrial sources.

China has been implementing PM control policies for several decades. Therefore, all of the projections reviewed here have assumed the future application of dust collectors to some extent. The $\mathrm{PM}_{10}$ emissions growth rate until 2020 of the least aggressive scenario in Xing et al. (2011) is comparable to our BAU[0], and the most aggressive one is comparable to our $\mathrm{PC}[1]$, indicating similar stringency levels of the control policies assumed in these two studies up until 2020. Amann et al. (2008) predicted a slight increase of $\mathrm{PM}_{2.5}$ emissions during 2005-2010, in contrast with a $12 \%$ decline estimated in our study using statistical data. However, the growth rate for the period 2010-2030 in their 
current legislation scenario is quite close to our BAU[0] scenario; the growth rates in their advanced control technology scenario and optimized scenario are close to our PC[1] scenario. Cofala et al. (2012) projected the change rate of $\mathrm{PM}_{2.5}$ emissions for 2010-2030 as between -20 and $-34 \%$ under four energy scenarios, which are comparable to the projected change rates of our BAU[0] $(-8 \%)$ and $\mathrm{PC}[0](-34 \%)$. Finally, it should be noted that our maximum feasible reduction scenario (the PC[2] scenario) projects much lower emissions than any previously developed scenario.

\subsubsection{NMVOC emissions}

Kurokawa et al. (2013) have estimated the recent trends in China's NMVOC emissions, which showed a slightly stronger upward trend (16\% growth during 2005-2008) than this study ( $9 \%$ growth for the same period).

Since 2005, only three studies have projected China's NMVOC emissions. Compared with our study, Ohara et al. (2007) made similar estimation of NMVOC emissions in 2010, but predicted much higher growth rates for the period 2010-2020 in all three of their scenarios, as they assumed few effective control measures in any scenario. Xing et al. (2011) and Wei et al. (2011b) have considered the effect of recent vehicle emission standards on NMVOC emissions, and assumed relatively simple but progressively strengthened control polices through 2020, and therefore achieved similar growth rates to ours for both baseline and progressive strategies. Given China is still in the initial stage of NMVOC emission controls, and limited new policies are expected to emerge in the next 5-10 years, the emission trends are unlikely to deviate greatly from the baseline through 2020 . However, control measures at different levels of stringency might result in dramatically different emissions by 2030 . Our study is the first one to quantify the effect of potential new policies on NMVOC emission trends through 2030 and to quantify the maximum feasible reduction potential using energy-saving policies and end-of-pipe control measures.

\subsection{Comparison with observations}

$\mathrm{SO}_{2}$ and $\mathrm{NO}_{2}$ retrievals from satellite observations are used for comparisons with trends of primary emissions estimated in this work. A more rigorous comparison would involve incorporating the emission inventory into a chemical transport model and comparing the simulated $\mathrm{NO}_{2}$ or $\mathrm{SO}_{2}$ column with satellite observations, which will be considered in future research. Lu et al. (2011) retrieved the satellite $\mathrm{SO}_{2}$ vertical column density (VCD) for eastern central China (latitude $<45^{\circ} \mathrm{N}$, longitude $>100^{\circ} \mathrm{E}$ ), in which measurements of the Ozone Monitoring Instrument (OMI) and SCanning Imaging Absorption spectroMeter for Atmospheric CHartographY (SCIAMACHY) during 2005-2010 were used. Fioletov et al. (2013) developed a filtering procedure to remove local biases, in particular transient volcanic signals, and applied this method to retrieve the $\mathrm{SO}_{2} \mathrm{VCD}$ over an area of eastern China during 2005-2010. The data sources include OMI, SCIAMACHY, the Global Ozone Monitoring Experiment-2 (GOME-2) German Aerospace Center (DLR) product, and the GOME-2 Smithsonian Astrophysical Observatory (SAO) product. It should be noted that the data of GOME-2 have only been available since 2007 . The comparison of $\mathrm{SO}_{2}$ VCDs derived by Lu et al. (2011) and Fioletov et al. (2013) with the estimated $\mathrm{SO}_{2}$ emissions are shown in Fig. 5a and b, respectively. It can be seen that the temporal trends of $\mathrm{SO}_{2}$ VCD retrieved by Fioletov et al. (2013) from all four data sources (OMI, SCIAMACHY, GOME-2 DLR, and GOME-2 SAO) agree well with each other. In addition, the trends of $\mathrm{SO}_{2} \mathrm{VCD}$ retrieved by Lu et al. (2011) agree well with that of Fioletov et al. (2013) during 2005-2009. However, Lu et al. (2011) shows a significant increase in $\mathrm{SO}_{2}$ VCD between 2009 and 2010 (especially that retrieved from SCIAMACHY), while Fioletov et al. (2013) shows a slight increase. Fioletov et al. (2013) implies that the pronounced increase between 2009 and 2010 arises from timedependent bias in the retrieval algorithms. When the filtering procedure developed in Fioletov et al. (2013) was applied, the pronounced increase turned into a slight increase. Therefore, we exclude the $\mathrm{SO}_{2} \mathrm{VCD}$ in 2010 in Lu et al. (2011) in the following discussion.

As shown in Fig. 5a, during 2005-2009, $\mathrm{SO}_{2} \mathrm{VCD}$ from OMI, $\mathrm{SO}_{2}$ VCD from SCIAMACHY, and estimated $\mathrm{SO}_{2}$ emissions decreased by 20,21 , and $17 \%$, respectively, in eastern central China. Similarly, during 2005-2010, the rate of decline of $\mathrm{SO}_{2} \mathrm{VCD}$ from OMI (16\%), $\mathrm{SO}_{2} \mathrm{VCD}$ from SCIAMACHY ( $8 \%$ ), and estimated $\mathrm{SO}_{2}$ emissions (15\%) agree fairly well with each other in the studied area of Fioletov et al. (2013). However, $\mathrm{SO}_{2} \mathrm{VCDs}$ from both SCIAMACHY and OMI peak in 2007, while this study shows a monotonic decline in $\mathrm{SO}_{2}$ emissions through 2009. This may be mainly attributable to the uncertainty in the actual removal efficiency and operation status of FGD facilities. Although FGD facilities have been rapidly introduced since 2005, the actual operation status has been questioned before by both the government and research community (Xu et al., 2009). In response to this situation, the Chinese government began to require the installation of continuous emission monitoring systems (CEMSs) together with FGD facilities since July 2007 (SEPA, 2007). Therefore, the average removal efficiency should have improved subsequently, contributing to the rapid decline in $\mathrm{SO}_{2}$ during 2007-2009. Despite the inconsistency above, the estimated overall change rate in $\mathrm{SO}_{2}$ emissions from 2005 to 2010 agrees fairly well with satellite observations, although this agreement is very sensitive to the choice of trend start and end years.

The $\mathrm{NO}_{2}$ VCDs were retrieved from OMI and SCIAMACHY with the method described in Zhao et al. (2013b) and Zhang et al. (2012a), respectively. Fig. 5c compares the average $\mathrm{NO}_{2} \mathrm{VCD}$ in eastern central China and the total $\mathrm{NO}_{\mathrm{x}}$ emissions in this area. It can be seen that the growing trend 

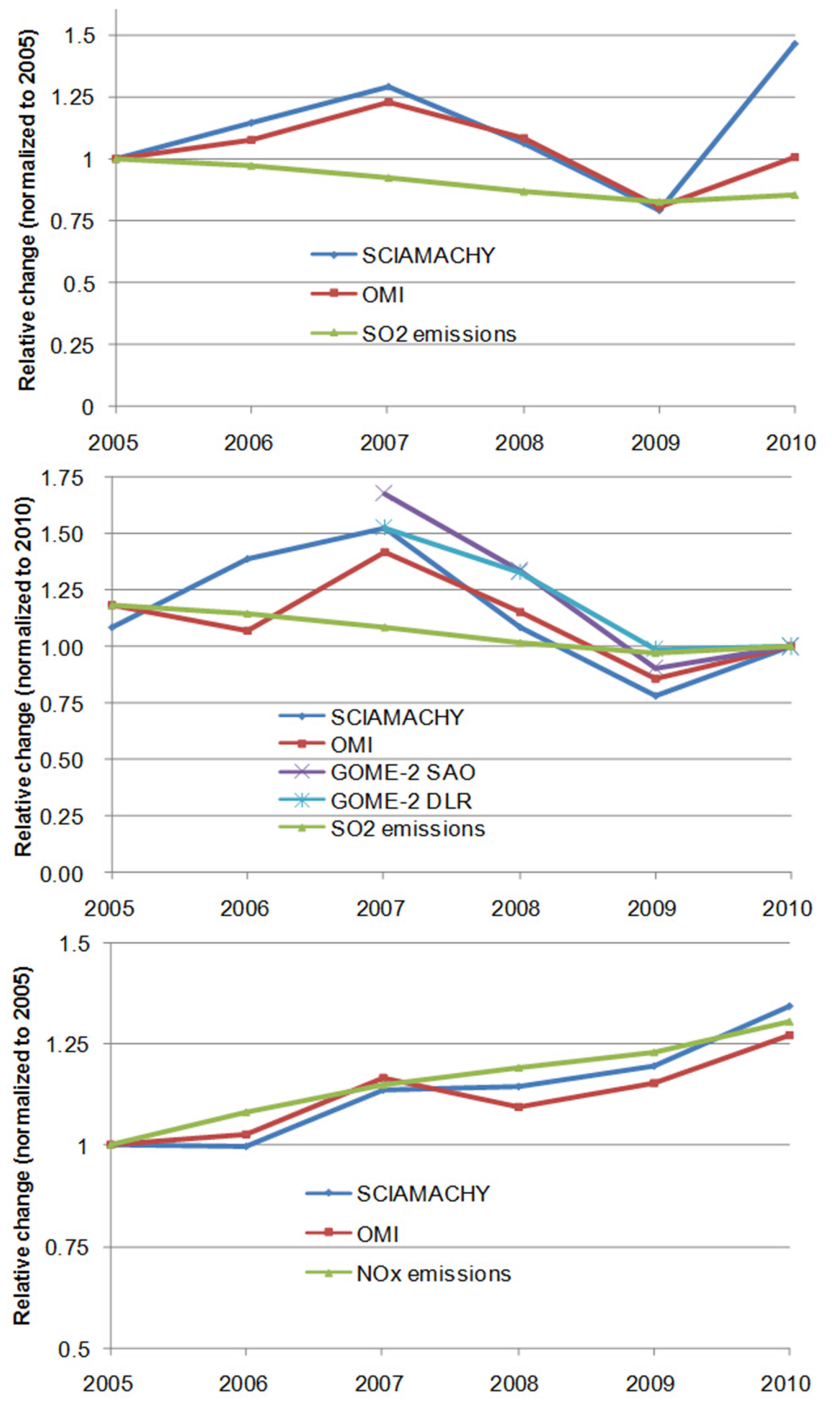

Figure 5. Inter-annual relative changes of $\mathrm{SO}_{2}$ and $\mathrm{NO}_{2} \mathrm{VCD}$ from satellite observations and estimated emissions in this study. Average $\mathrm{SO}_{2} \mathrm{VCD}$ and total $\mathrm{SO}_{2}$ emissions in eastern central China (latitude $<45^{\circ} \mathrm{N}$, longitude $\left.>100^{\circ} \mathrm{E}\right)\left(\right.$ a). $\mathrm{SO}_{2} \mathrm{VCD}$ was derived by $\mathrm{Lu}$ et al. (2011). All data are normalized to 2005. Average $\mathrm{SO}_{2}$ VCD and total $\mathrm{SO}_{2}$ emissions over an area of eastern China $\left(34-38^{\circ} \mathrm{N}, 112-\right.$ $118^{\circ}$ E) (b). $\mathrm{SO}_{2}$ VCD was derived by Fioletov et al. (2013), in which a filtering procedure was applied to remove local biases, in particular volcanic signals. All data are normalized to 2010 because the data of GOME-2 have only been available since 2007. Average $\mathrm{NO}_{2} \mathrm{VCD}$ and total $\mathrm{NO}_{\mathrm{x}}$ emissions in eastern central China (c). $\mathrm{NO}_{2} \mathrm{VCD}$ was retrieved from OMI and SCIAMACHY in this study. All data are normalized to 2005.

of $\mathrm{NO}_{\mathrm{x}}$ emissions are well captured by both the observations of OMI and SCIAMACHY. The growth rates of $\mathrm{NO}_{2} \mathrm{VCD}$ from OMI, $\mathrm{NO}_{2}$ VCD from SCIAMACHY, and $\mathrm{NO}_{\mathrm{x}}$ emissions are 27,34 , and $31 \%$, respectively.

The trends in PM concentrations are not directly comparable with primary emissions, as secondary PM is formed through complex chemical reactions of primary pollutants. Our previous study (Zhao et al., 2013a) simulated the concentrations of air pollutants in China in 2005 and 2010 using the Community Multi-scale Air Quality (CMAQ) model and the same emission inventory as presented in this paper. The trends of air pollutant emissions were evaluated by comparing the trends of simulated air quality with observations. From 2005 to 2010, the simulated $\mathrm{PM}_{10}$ concentrations of 58 Chinese cities decreased by $7.3 \%$, which agreed well with the rate of decline of the observations $(7.6 \%$, http:// datacenter.mep.gov.cn). In addition, the simulated changes of aerosol optical depth (AOD) during 2005-2010 can well reproduce the spatial pattern of the AOD changes observed by Moderate Resolution Imaging Spectroradiometer (MODIS). During 2005-2010, AOD decreased in some areas such as the southeast coast of China, but increased over large parts of China, with especially pronounced increases in the Sichuan Basin and the southern part of the North China Plain (Zhao et al., 2013a).

As described above, both observation and simulation results indicate that annual average $\mathrm{PM}_{10}$ concentrations in major cities of eastern China decreased since 2005. However, based on our simulation results (Zhao et al., 2013a), the control policies had not been successful in reducing concentrations of fine particles over large parts of China. One of the important reasons for the increase of fine particles during 2005-2010 is that nitrate concentrations increased in most of China driven by the increase of $\mathrm{NO}_{\mathrm{x}}$ and $\mathrm{NH}_{3}$ emissions. Although sulfate concentrations in East China decreased due to the decline of $\mathrm{SO}_{2}$ emissions, the concentrations of secondary inorganic aerosol (SIA) increased in most of China, especially in the Sichuan Basin and eastern Hubei province. In addition, the increase in the emissions of NMVOC led to the increase of secondary organic aerosols. The increase in secondary $\mathrm{PM}_{2.5}$ concentrations offset the decline of primary $\mathrm{PM}_{2.5}$ concentrations and led to the increase of total $\mathrm{PM}_{2.5}$ concentrations over large parts of China. Given above, although the emissions of primary $\mathrm{PM}$ and $\mathrm{SO}_{2}$ decreased in most of China, the modeling results indicated that total $\mathrm{PM}_{2.5}$ concentrations still increased over large parts of China (Zhao et al., 2013a).

\section{Conclusions and policy implications}

In this study we reviewed the application status of air pollution control measures in East Asia in the last decade, evaluated the impact of control policies on the emission trends during 2005-2010, and projected future emissions of $\mathrm{SO}_{2}$, $\mathrm{NO}_{\mathrm{x}}, \mathrm{PM}_{10}, \mathrm{PM}_{2.5}$, and NMVOC up until 2030 under six emission scenarios based on a range of energy-saving and end-of-pipe emission control measures.

During 2005-2010, the emissions of $\mathrm{SO}_{2}$ and $\mathrm{PM}_{2.5}$ in East Asia decreased by 15 and $12 \%$, respectively, mainly attributable to the large scale deployment of FGD in China's 
power plants, and the deployment of more efficient PM removal technologies in China's power and cement plants. During this period, the emissions of $\mathrm{NO}_{\mathrm{x}}$ and NMVOC increased by 25 and $15 \%$, respectively, driven by the rapid increase in the emissions from China due to inadequate control strategies. In contrast, the $\mathrm{NO}_{\mathrm{x}}$ and NMVOC emissions in East Asia other than China decreased by $13-17 \%$ mainly due to the implementation of stringent vehicle emission standards in Japan and South Korea.

Under current regulations and implementation status (the BAU[0] scenario), $\mathrm{NO}_{\mathrm{x}}, \mathrm{SO}_{2}$, and $\mathrm{NMVOC}$ emissions in East Asia are estimated to increase by about one-quarter by 2030 from the 2010 levels, while $\mathrm{PM}_{2.5}$ emissions are expected to decrease by $7 \%$. Assuming enforcement of new energy-saving policies, emissions of $\mathrm{NO}_{\mathrm{x}}, \mathrm{SO}_{2}, \mathrm{PM}_{2.5}$, and NMVOC in East Asia are expected to decrease by 28, 36, 28 , and $15 \%$, respectively, compared with the baseline case. The implementation of progressive end-of-pipe control measures is expected to lead to another one-third reduction of the baseline emissions of $\mathrm{NO}_{\mathrm{x}}$, and about one-quarter reduction of $\mathrm{SO}_{2}, \mathrm{PM}_{2.5}$, and NMVOC. Exploring the potential of currently known best available technologies, their full implementation could reduce the emissions of $\mathrm{NO}_{\mathrm{x}}, \mathrm{SO}_{2}$, and $\mathrm{PM}_{2.5}$ in East Asia to only about one-quarter, and NMVOC to one-third, of the levels of the baseline projection.

A comparison with emission projections in the literature indicates that this study: (1) estimates similar recent emission trends until 2010; (2) projects larger reductions in $\mathrm{NO}_{\mathrm{x}}$ and $\mathrm{SO}_{2}$ emissions by assuming aggressive governmental plans and standards scheduled to be implemented in the next decade; (3) accounts for the significant effects of detailed progressive control measures on NMVOC emissions up until 2030; and (4) quantifies technically feasible reduction potentials. The results of this study provide future emission projections for the modeling community of the MICS-Asia program, allowing modelers to assess the impact of emission changes on future air quality. In addition, the emission projections at various stringency levels from a business-as-usual case to a maximum feasible reduction case provide a basis for further studies on cost-effective emission control strategies, which can balance control measures over all pollutants and control levels.

The results of this study have important policy implications. First, this study indicates that the successful implementation of the control policies set in China's 12th Five-Year Plan, the recently released emission standards for various industrial sources, and slowly strengthened control measures after 2015 (as assumed in the "progressive" end-of-pipe control strategy) could reduce China's emissions of $\mathrm{NO}_{\mathrm{x}}, \mathrm{SO}_{2}$, and $\mathrm{PM}_{2.5}$ significantly. The resulting $\mathrm{NO}_{\mathrm{x}}, \mathrm{SO}_{2}$, and $\mathrm{PM}_{2.5}$ emissions would be $16-26 \%$ lower than the 2010 levels by 2020 , and even lower by 2030, demonstrating a high mitigation potential when this legislation and associated regulations are enforced efficiently. Therefore, we believe it is essential to support and monitor the progress of implementation of these measures. Second, the contributions of advanced energy-saving measures to the reduction of $\mathrm{SO}_{2}$ and $\mathrm{PM}_{2.5}$ emissions exceeds those of progressive end-of-pipe control measures by 2030. Since end-of-pipe control technologies (e.g., FGD facilities and high-efficiency dedusters) have already been widely applied in typical sources in the base year, their reduction potential will diminish in the future. Energysaving measures would play an essential role for further reduction of air pollutant emissions. Third, control policies for NMVOC emissions are unfortunately lacking in China and South Korea at present; this study indicates that the simultaneous enforcement of energy-saving measures and progressive end-of-pipe control measures (mainly assuming enforcement of European standards) could reduce $38 \%$ of the total NMVOC emissions from the levels of baseline projection. Nevertheless, large reduction potential still remains, and additional policies to reduce NMVOC emissions efficiently and effectively warrant careful consideration .

\section{The Supplement related to this article is available online at doi:10.5194/acp-14-6571-2014-supplement.}

Acknowledgements. 1. Please revise the Acknowledgements to as follows, This work was sponsored by the National Natural Science Foundation of China (21221004), Strategic Priority Research Program of the Chinese Academy of Sciences (XBD05020300), MEP's Special Funds for Research on Public Welfare (201309009, 201409002) and special fund of State Key Joint Laboratory of Environment Simulation and Pollution Control (12L05ESPC). The corresponding author, S. Wang, is supported by the Program for New Century Excellent Talents in University (NCET-10-0532) and the China Scholarship Council. The authors also appreciate the support from Collaborative Innovation Center for Regional Environmental Quality of Tsinghua University.

Edited by: D. Shindell

\section{References}

Amann, M., Jiang, K. J., Hao, J. M., and Wang, S. X.: Scenarios for cost-effective control of air pollution and greenhouse gases in China, International Institute for Applied Systems Analysis, Laxenburg, Austria, 51, 2008.

Amann, M., Bertok, I., Borken-Kleefeld, J., Cofala, J., Heyes, C., Hoglund-Isaksson, L., Klimont, Z., Nguyen, B., Posch, M., Rafaj, P., Sandler, R., Schopp, W., Wagner, F., and Winiwarter, W.: Cost-effective control of air quality and greenhouse gases in Europe: Modeling and policy applications, Environ. Modell. Softw., 26, 1489-1501, doi:10.1016/j.envsoft.2011.07.012, 2011.

Bo, Y., Cai, H., and Xie, S. D.: Spatial and temporal variation of historical anthropogenic NMVOCs emission inventories in China, Atmos. Chem. Phys., 8, 7297-7316, doi:10.5194/acp-8-72972008, 2008. 
China Electric Power Yearbook Committee: China Electric Power Yearbook 2006, China Electric Power Press, Beijing, China, 2006 (in Chinese).

China Electric Power Yearbook Committee: China Electric Power Yearbook 2011, China Electric Power Press, Beijing, China, 2011 (in Chinese).

Cofala, J., Amann, M., Klimont, Z., Kupiainen, K., and HoglundIsaksson, L.: Scenarios of global anthropogenic emissions of air pollutants and methane until 2030, Atmos. Environ., 41, 84868499, doi:10.1016/j.atmosenv.2007.07.010, 2007.

Cofala, J., Bertok, I., Borken-Kleefeld, J., Heyes, C., Klimont, Z., Rafaj, P., Sander, R., Schöpp, W., and Amann, A.: Emissions of Air Pollutants for the World Energy Outlook 2012 Energy Scenarios, International Institute for Applied Systems Analysis, Laxenburg, Austria, 2012.

Delphi Company: Worldwide Emission Standard: Heavy Duty and Off-Highway Vehicles, available at www.delphi.com/ emissions-hd (last access: 1 November 2013), Delphi company, Troy, Michigan, US, 100 pp., 2013a.

Delphi Company: Worldwide Emission Standard: Passenger Cars and Light Duty Vehicles, available at www.delphi.com/ emissions-pc (last access: 1 November 2013), Delphi company, Troy, Michigan, US, 100 pp., 2013 b.

Energy Conservation Center of Japan: Japan Energy Conservation Handbook 2011, available at http://www.asiaeec-col.eccj.or.jp/ databook/2011/ (last access: 1 October 2013), Energy Conservation Center of Japan, Tokyo, Japan, 145 pp., 2011.

Fioletov, V. E., McLinden, C. A., Krotkov, N., Yang, K., Loyola, D. G., Valks, P., Theys, N., Van Roozendael, M., Nowlan, C. R., Chance, K., Liu, X., Lee, C., and Martin, R. V.: Application of OMI, SCIAMACHY, and GOME-2 satellite $\mathrm{SO}_{2}$ retrievals for detection of large emission sources, J. Geophys. Res-Atmos., 118, 11399-11418, doi:10.1002/jgrd.50826, 2013.

Huo, H., Lei, Y., Zhang, Q., Zhao, L. J., and He, K. B.: China's coke industry: Recent policies, technology shift, and implication for energy and the environment, Energ. Policy., 51, 397-404, 2012.

Institute of Energy Economics of Japan: Handbook of Energy \& Economic Statistics in Japan, Institute of Energy Economics of Japan, Tokyo, Japan, 370 pp., 2010.

International Energy Agency (IEA): Energy Balances of OECD Countries 1999-2000, International Energy Agency, Head of Publications Service, Paris, France, 249 pp., 2002.

International Energy Agency (IEA): Energy policy of IEA countries: Korea 2006 Review, International Energy Agency, Paris, France, 2006.

International Energy Agency (IEA): Energy Balances of OECD Countries 2004-2005, International Energy Agency, Head of Publications Service, Paris, France, 249 pp., 2007.

International Energy Agency (IEA): Energy policy of IEA countries: Japan 2008 Review, International Energy Agency, Paris, France, 2008.

International Energy Agency (IEA): World Energy Outlook 2009, International Energy Agency, Paris, France, 2009.

International Energy Agency (IEA): Energy policy of IEA countries: Korea 2012 Review, International Energy Agency, Paris, France, 2012a.

International Energy Agency (IEA): Energy Balances of OECD Countries 2009-2010, International Energy Agency, Head of Publications Service, Paris, France, 249 pp., 2012 b.
Japan Automobile Manufacturers Association: PM/PM2.5 in Ambient Air \& Related Activities in Japan, Japan Automobile Manufacturers Association, Tokyo, Japan, 51 pp., 2011.

Japan Petroleum Energy Center (JPEC): Emission inventory of road transport in Japan, Japan Petroleum Energy Center, Tokyo, 136, 2012a (in Japanese).

Japan Petroleum Energy Center (JPEC): Emission inventory of sources other than road transport in Japan, Japan Petroleum Energy Center, Tokyo, 288, 2012b (in Japanese).

Japan Petroleum Energy Center (JPEC): Speciation profiles of VOC, $\mathrm{PM}$, and $\mathrm{NO}_{\mathrm{x}}$ emissions for atmospheric simulations of $\mathrm{PM}_{2.5}$, Japan Petroleum Energy Center, Tokyo, 69, 2012c (in Japanese).

Klimont, Z., Cofala, J., Schopp, W., Amann, M., Streets, D. G., Ichikawa, Y., and Fujita, S.: Projections of $\mathrm{SO}_{2}, \mathrm{NO}_{\mathrm{x}}, \mathrm{NH}_{3}$ and VOC emissions in East Asia up to 2030, Water. Air. Soil. Poll., 130, 193-198, 2001.

Klimont, Z., Streets, D. G., Gupta, S., Cofala, J., Fu, L. X., and Ichikawa, Y.: Anthropogenic emissions of non-methane volatile organic compounds in China, Atmos. Environ., 36, 1309-1322, doi:10.1016/S1352-2310(01)00529-5, 2002.

Klimont, Z., Cofala, J., Xing, J., Wei, W., Zhang, C., Wang, S., Kejun, J., Bhandari, P., Mathur, R., Purohit, P., Rafaj, P., Chambers, A., and Amann, M.: Projections of $\mathrm{SO}_{2}, \mathrm{NO}_{\mathrm{x}}$ and carbonaceous aerosols emissions in Asia, Tellus B, 61, 602-617, doi:10.1111/j.1600-0889.2009.00428.x, 2009.

Klimont, Z., Smith, S. J., and Cofala, J.: The last decade of global anthropogenic sulfur dioxide: 2000-2011 emissions, Environ. Res. Lett., 8, 014003, doi:10.1088/1748-9326/8/1/014003, 2013.

Kurokawa, J., Ohara, T., Morikawa, T., Hanayama, S., JanssensMaenhout, G., Fukui, T., Kawashima, K., and Akimoto, H.: Emissions of air pollutants and greenhouse gases over Asian regions during 2000-2008: Regional Emission inventory in ASia (REAS) version 2, Atmos. Chem. Phys., 13, 11019-11058, doi:10.5194/acp-13-11019-2013, 2013.

Lei, Y., Zhang, Q., He, K. B., and Streets, D. G.: Primary anthropogenic aerosol emission trends for China, 1990-2005, Atmos. Chem. Phys., 11, 931-954, doi:10.5194/acp-11-931-2011, 2011.

Li, C., Zhang, Q., Krotkov, N. A., Streets, D. G., He, K. B., Tsay, S. C., and Gleason, J. F.: Recent large reduction in sulfur dioxide emissions from Chinese power plants observed by the Ozone Monitoring Instrument, Geophys. Res. Lett., 37, L08807, doi:10.1029/2010GL042594, 2010.

Li, Y.: Dynamics of clean coal-fired power generation development in China, Energ. Policy, 51, 138-142, doi:10.1016/j.enpol.2011.06.012, 2012.

Lin, J. T., Nielsen, C. P., Zhao, Y., Lei, Y., Liu, Y., and McElroy, M. B.: Recent Changes in Particulate Air Pollution over China Observed from Space and the Ground: Effectiveness of Emission Control, Environ. Sci. Technol., 44, 7771-7776, doi:10.1021/Es101094t, 2010a.

Lin, J.-T., McElroy, M. B., and Boersma, K. F.: Constraint of anthropogenic $\mathrm{NO}_{\mathrm{x}}$ emissions in China from different sectors: a new methodology using multiple satellite retrievals, Atmos. Chem. Phys., 10, 63-78, doi:10.5194/acp-10-63-2010, 2010 b.

Liu, H. Y., Jacob, D. J., Bey, I., Yantosca, R. M., Duncan, B. N., and Sachse, G. W.: Transport pathways for Asian pollution outflow over the Pacific: Interannual and seasonal variations, J. Geophys. Res-Atmos., 108, 8786, doi:10.1029/2002JD003102, 2003. 
Lu, Z., Streets, D. G., Zhang, Q., Wang, S., Carmichael, G. R., Cheng, Y. F., Wei, C., Chin, M., Diehl, T., and Tan, Q.: Sulfur dioxide emissions in China and sulfur trends in East Asia since 2000, Atmos. Chem. Phys., 10, 6311-6331, doi:10.5194/acp-106311-2010, 2010.

Lu, Z., Zhang, Q., and Streets, D. G.: Sulfur dioxide and primary carbonaceous aerosol emissions in China and India, 1996-2010, Atmos. Chem. Phys., 11, 9839-9864, doi:10.5194/acp-11-98392011, 2011.

Ministry of Environment of South Korea: Air \& Climate Change Policies in South Korea, http://eng.me.go.kr/eng/web/index.do? menuId=64\&findDepth=1 (last access: 23 January 2014), 2013.

Ministry of Environmental Protection of China (MEP): Bulletin of urban sewage treatment facilities, and flue gas desulfurization/denitrification facilities of coal-fired power plants, http://www.mep.gov.cn/gkml/hbb/bgg/201104/t20110420_ 209449.htm (last access: 5 May 2012), 2011 (in Chinese).

Ministry of the Environment of Japan: Air \& Transportation Policies in Japan, http://www.env.go.jp/en/air/, last access: 1 August 2013.

National Bureau of Statistics (NBS): China Energy Statistical Yearbook 2006, China Statistics Press, Beijing, 2007.

National Bureau of Statistics (NBS): China Energy Statistical Yearbook 2007, China Statistics Press, Beijing, 2008a.

National Bureau of Statistics (NBS): China Energy Statistical Yearbook 2008, China Statistics Press, Beijing, 2008b.

National Bureau of Statistics (NBS): China Energy Statistical Yearbook 2009, China Statistics Press, Beijing, 2009.

National Bureau of Statistics (NBS): China Energy Statistical Yearbook 2011, China Statistics Press, Beijing, 2011a.

National Bureau of Statistics (NBS): China Energy Statistical Yearbook 2010, China Statistics Press, Beijing, 2011b.

National Development and Reform Commission (NDRC): Bulletin of the progress in shutting down small power generation units, http://bgt.ndrc.gov.cn/zcfb/201104/t20110422_500043.html (last access: 23 June 2014), 2011 (in Chinese).

National Institute of Environmental Research (NIER): The methodology of national air pollutants emission estimation II, 2010, National Institute of Environmental Research, Inchon, South Korea, 2010 (in Korean).

National Institute of Environmental Research (NIER): A Study on the Characteristics of the Process Facilities using SEMS Data, National Institute of Environmental Research, Inchon, South Korea, 2013 (in Korean).

Ohara, T., Akimoto, H., Kurokawa, J., Horii, N., Yamaji, K., Yan, X., and Hayasaka, T.: An Asian emission inventory of anthropogenic emission sources for the period 1980-2020, Atmos. Chem. Phys., 7, 4419-4444, doi:10.5194/acp-7-4419-2007, 2007.

Shindell, D., Kuylenstierna, J. C. I., Vignati, E., van Dingenen, R., Amann, M., Klimont, Z., Anenberg, S. C., Muller, N., Janssens-Maenhout, G., Raes, F., Schwartz, J., Faluvegi, G., Pozzoli, L., Kupiainen, K., Hoglund-Isaksson, L., Emberson, L., Streets, D., Ramanathan, V., Hicks, K., Oanh, N. T. K., Milly, G., Williams, M., Demkine, V., and Fowler, D.: Simultaneously Mitigating Near-Term Climate Change and Improving Human Health and Food Security, Science, 335, 183-189, doi:10.1126/science.1210026, 2012.
State Environmental Protection Administration (SEPA): Administrative regulations for the application of desulfurization electricity price and the operation of flue gas desulfurization facilities in coal-fired power generation units, http://www.zhb.gov.cn/gkml/ hbb/gwy/200910/t20091030_180711.htm (last access: 23 June 2014), 2007 (in Chinese).

Streets, D. G. and Waldhoff, S. T.: Present and future emissions of air pollutants in China: $\mathrm{SO}_{2}, \mathrm{NO}_{\mathrm{x}}$, and $\mathrm{CO}$, Atmos. Environ., 34, 363-374, 2000.

The State Council of the People's Republic of China: The Eleventh Five-Year Plan for National Economic and Social Development of the People's Republic of China, http://www. gov.cn/gongbao/content/2006/content_268766.htm (last access: 2 February 2013), 2006 (in Chinese).

The State Council of the People's Republic of China: Integrated Work Plan for Energy Saving and Emission Reduction During the Twelfth Five-Year Plan, http://www.gov.cn/zwgk/2011-09/ 07/content_1941731.htm (last access: 2 February 2013), 2011 (in Chinese).

The State Council of the People's Republic of China: The Twelfth Five-Year Plan for Energy Saving and Emission Reduction, http: //www.gov.cn/zwgk/2012-08/21/content_2207867.htm (last access: 2 February 2013), 2012 (in Chinese).

Tsinghua University Building Energy Research Center (THUBERC): Annual Report on China Building Energy Efficiency, China Architecture \& Building Press, Beijing, 2009 (in Chinese).

United Nations Environment Programme (UNEP): Overview of the Republic of Korea's National Strategy for Green Growth, United Nations Environment Programme, Geneva, Switzerland, 54 pp., 2010.

United Nations Environment Programme (UNEP), and World Meteorological Organization (WMO): Integrated Assessment of Black Carbon and Tropospheric Ozone, United Nations Environment Programme and World Meteorological Organization, Nairobi, Kenya, 2011.

van Aardenne, J. A., Carmichael, G. R., Levy, H., Streets, D., and Hordijk, L.: Anthropogenic $\mathrm{NO}_{\mathrm{x}}$ emissions in Asia in the period 1990-2020, Atmos. Environ., 33, 633-646, 1999.

Wakamatsu, S., Morikawa, T., and Ito, A.: Air Pollution Trends in Japan between 1970 and 2012 and Impact of Urban Air Pollution Countermeasures, Asian J. Atmos. Environ., 7, 177-190, doi:10.5572/ajae.2013.7.4.177, 2013.

Wang, Q. Y.: Chinese Energy Data 2010, The Energy Foundation, Beijing, 109 pp., 2010.

Wang, S. X. and Hao, J. M.: Air quality management in China: Issues, challenges, and options, J. Environ. Sci.-China, 24, 2-13, doi:10.1016/S1001-0742(11)60724-9, 2012.

Wei, W., Wang, S. X., Chatani, S., Klimont, Z., Cofala, J., and Hao, J. M.: Emission and speciation of non-methane volatile organic compounds from anthropogenic sources in China, Atmos. Environ., 42, 4976-4988, 2008.

Wei, W., Wang, S. X., and Hao, J. M.: Uncertainty Analysis of Emission Inventory for Volatile Organic Compounds from Anthropogenic Sources in China, Environ. Sci., 32, 305-312, 2011a (in Chinese).

Wei, W., Wang, S. X., Hao, J. M., and Cheng, S. Y.: Projection of anthropogenic volatile organic compounds (VOCs) emissions in China for the period 2010-2020, Atmos. Environ., 45, 68636871, doi:10.1016/j.atmosenv.2011.01.013, 2011 b. 
World Bank (WB), and State Environmental Protection Administration (SEPA): Cost of Pollution in China: Economic Estimates of Physical Damages, available at www.worldbank.org/ eapenvironment (last access: 1 October 2013), 2007.

Wu, Y., Zhang, S. J., Li, M. L., Ge, Y. S., Shu, J. W., Zhou, Y., Xu, Y. Y., Hu, J. N., Liu, H., Fu, L. X., He, K. B., and Hao, J. M.: The challenge to $\mathrm{NO}_{\mathrm{x}}$ emission control for heavy-duty diesel vehicles in China, Atmos. Chem. Phys., 12, 9365-9379, doi:10.5194/acp12-9365-2012, 2012.

Xing, J., Wang, S. X., Chatani, S., Zhang, C. Y., Wei, W., Hao, J. M., Klimont, Z., Cofala, J., and Amann, M.: Projections of air pollutant emissions and its impacts on regional air quality in China in 2020, Atmos. Chem. Phys., 11, 3119-3136, doi:10.5194/acp-113119-2011, 2011.

Xu, Y., Williams, R. H., and Socolow, R. H.: China's rapid deployment of $\mathrm{SO}_{2}$ scrubbers, Energ. Environ. Sci., 2, 459-465, 2009.

Yang, Z. D.: Well-to-wheels analysis of energy consumption and $\mathrm{CO}_{2}$ emissions of electric-powered vehicles in China, Master thesis, School of Environment, Tsinghua University, Beijing, China, 83 pp., 2012 (in Chinese).

Zhang, Q., Streets, D. G., He, K., Wang, Y., Richter, A., Burrows, J. P., Uno, I., Jang, C. J., Chen, D., Yao, Z., and Lei, Y.: $\mathrm{NO}_{\mathrm{x}}$ emission trends for China, 1995-2004: The view from the ground and the view from space, J. Geophys. Res-Atmos., 112, D22306, doi:10.1029/2007jd008684, 2007.

Zhang, Q., Geng, G. N., Wang, S. W., Richter, A., and He, K. B.: Satellite remote sensing of changes in $\mathrm{NO}_{\mathrm{x}}$ emissions over China during 1996-2010, Chinese Sci. Bull., 57, 2857-2864, doi:10.1007/s11434-012-5015-4, 2012a.

Zhang, Q., He, K. B., and Huo, H.: Cleaning China's air, Nature, 484, 161-162, 2012b.
Zhang, X. Y., Wang, Y. Q., Niu, T., Zhang, X. C., Gong, S. L., Zhang, Y. M., and Sun, J. Y.: Atmospheric aerosol compositions in China: spatial/temporal variability, chemical signature, regional haze distribution and comparisons with global aerosols, Atmos. Chem. Phys., 12, 779-799, doi:10.5194/acp12-779-2012, 2012.

Zhao, B., Wang, S. X., Dong, X. Y., Wang, J. D., Duan, L., Fu, X., Hao, J. M., and Fu, J.: Environmental effects of the recent emission changes in China: implications for particulate matter pollution and soil acidification, Environ. Res. Lett., 8, 024031, doi:10.1088/1748-9326/8/2/024031, 2013a.

Zhao, B., Wang, S. X., Wang, J. D., Fu, J., Liu, T. H., Xu, J. Y., $\mathrm{Fu}, \mathrm{X}$., and Hao, J. M.: Impact of national $\mathrm{NO}_{\mathrm{X}}$ and $\mathrm{SO}_{2}$ control policies on particulate matter pollution in China, Atmos. Environ., 77, 453-463, 2013b.

Zhao, B., Wang, S. X., Liu, H., Xu, J. Y., Fu, K., Klimont, Z., Hao, J. M., He, K. B., Cofala, J., and Amann, M.: $\mathrm{NO}_{\mathrm{x}}$ emissions in China: historical trends and future perspectives, Atmos. Chem. Phys., 13, 9869-9897, doi:10.5194/acp-13-9869-2013, $2013 \mathrm{c}$.

Zhao, Y., Wang, S. X., Nielsen, C. P., Li, X. H., and Hao, J. M.: Establishment of a database of emission factors for atmospheric pollutants from Chinese coal-fired power plants, Atmos. Environ., 44, 1515-1523, doi:10.1016/j.atmosenv.2010.01.017, 2010.

Zhao, Y., Zhang, J., and Nielsen, C. P.: The effects of recent control policies on trends in emissions of anthropogenic atmospheric pollutants and $\mathrm{CO}_{2}$ in China, Atmos. Chem. Phys., 13, 487-508, doi:10.5194/acp-13-487-2013, $2013 \mathrm{~d}$. 